WSRC-RP- $-92-315$

DE93 005545

\title{
Uranium in the Savannah River Site Environment (U)
}

A. G. Evans, L. R. Bauer, J. S. Haselow, D. W. Hayes, H. L. Martin, W. L. McDowell, \& J. B. Pickett

Westinghouse Savannah River Company

Savannah River Site

Aiken, SC 29808

Prepared for the U. S. Depaı iment of Energy under contract No. DE-AC09-89SR18035 
This document does not contain unclassified controlled nuclear information

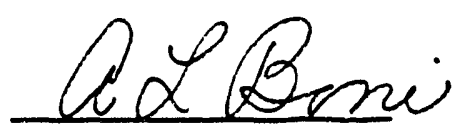

A. L. Boni

Authorized Derivative Classifier

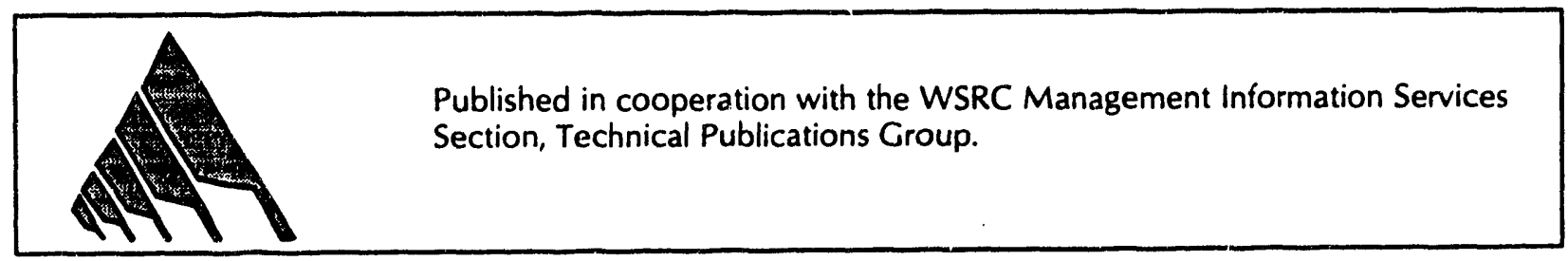




\section{Contents}

Preface

Chapter 1. Introduction

Environmental Uranium 1-1

Uranium in the Savannah River Site Environment 1-2

References 1-3

Chapter 2.

Uranium Releases to the Environment

Specific Uranium Analyses and Unidentified Alpha 2-1

Releases From Separations Facilities 2-2

F Area 2-2

F-Area Releases to Atmosphere 2-2

F-Area Releases to Seepage Jasins 2-3

F-Area Releases to Streams 2-3

H Area 2-5

H-Area Releases to Atmosphere 2-5

H-Area Releases to Seepage Basins 2-5

H-Area Releases to Streams 2-5

\section{Releases From Fuel Fabrication Facilities 2-7}

M Area Releases to Atmosphere 2-7

M-Area Releases to Streams 2-7

M-Area Releases to Seepage Basin 2-8 
Releases From Savannah River Laboratory Area 2-10

SRL Releases to Atmosphere 2-10

SRL Releases to Seepage Basins 2-10

SRL Releases to Streams 2-11

Releases From CMX/TNX 2-12

Releases From Reactor Areas $\quad 2-13$

D-Area Releases To Streams 2-17

Central Shops Releases To Seepage Basins 2-18

Uranium In The Solid Waste Disposal Facility 2-19

References 2-20

Chapter 3.

Uranium Concentrations and Transport at SRS

Surface Water Transport Of Uranium 3-1

Monitoring for Uranium in SRS Streams and the Savannah River 3-2

Releases of Uranium to SRS Streams 3-2

Uranium in SRS Streams 3-2

Tims Branch, A Tributary of Upper Three Runs 3-2

Upper Three Runs Creek 3-8

Other SRS Streams and the Savannah River 3-9

Summary $\quad 3-10$

Atmospheric Transport Of Uranium 3-11

Groundwater Transport Of Uranium 3-13

The SRS Groundwater System 3-13

F-Area Seepage Basins 3-14

H-Area Seepage Basins 3-15

M-Area Settling Basin and Lost Lake 3-16

SRL Seepage Basins 3-16 
CMX/TNX Seepage Basins 3-17

Old TNX Seepage Basin 3-17

TNX Burying Ground 3-17

Other Locations 3-18

References 3-19

Chapter 4.

Health Effects and Biological Fate of Uranium in Man

General Considerations of Uranium Toxicity 4-1

Uranium Intake Rate and Body Burden 4-2

Distribution and Retention in the Body 4-3

Chemical Toxicity 4-4

Mechanisms of Action 4-4

Evaluating Chemically-Based Doses and Risks 4-4

Carcinogens 4-4

Noncarcinogens 4-4

Toxicity Constants 4-4

Uranium as an Indicator of Chemical Toxicity 4-5

Radiological Toxicity 4-6

The Radiological Decay Process 4-6

Tissues at Risk from Radiation-Induced Damage 4-6

Uranium in Bone 4-6

Uranium in the Lungs 4-7

Evaluating Radiation Doses and Risks 4-7

Summary 4-8

References 4-9 
Chapter 5.

Impacts of SRS Uranium Releases on the Offsite Population

Models of Uranium Transport and Dose 5-1

Modeling Atmospheric Dispersion of Radioactive Releases 5-1 MAXIGASP $5-2$

POPGASP 5-2

Modeling Doses from Liquid Releases $\quad \mathbf{5 - 2}$

Verification of Models Using Monitoring Data 5-7

Atmospheric Releases 5-7

Liquid Releases 5-7

SRS Uranium Releases as a Chemical Hazard 5-8

Surface Water Concentrations 5-8

Air Concentrations $\quad$ 5-8

SRS Uranium Releases as a Radiological Hazard 5-10

DOE Internal Dose Factors 5-10

Impact of SRS Uranium Releases on the Offsite Population 5-10

Doses from Atmospheric Releases 5-10

Doses from Liquid Releases $\quad 5-12$

Summary 5-14

References 5-15

Chapter 6.

Environmental Monitoring Of Concentrations And Releases

Methods Of Detection 6-1

Atmospheric Monitoring 6-2

Separation and Fabrication Facilities 6-2

Open Air Monitoring $\quad$ 6-2 
Water Monitoring $\quad$ 6-3

Uranium In Surface Water 6-3

Uranium In Ground Water 6-4

Uranium In Foods 6-5

Data Reporting 6-6

TOC -5 


\section{Preface}

The purpose of this report is to consolidate the history of environmental uranium studies conducted by SRS and to describe the status of uranium in the environment. The report is intended to be a "living document" that will be updated periodically. This draft issue, February 1992, documents studies that occurred from 1954 to 1989.

Data in this report are taken primarily from annual and semiannual environmental reports for SRS. Semiannual reports were published from 1954 through 1962. Annual reports have been published since 1963. Occasionally unpublished data are included in this report for completeness. 
Chapter 1. Introduction 


\section{Environmental Uranium}

Uranium is a universally present element that can be found in surface soils and water supplies in virtually all parts of the world. The global concentration of uranium is roughly 0.2 parts per million (ppm) in soil. This value includes known ore deposits that range from $282 \mathrm{ppm}$ sandstones to some small pitchblend deposits that run as high as $169,600 \mathrm{ppm}$ (Eisenbud, 1987). In naturally occurring, non-ore rocks, uranium concentrations may range from $0.03 \mathrm{ppm}$ in some areas and up to $400 \mathrm{ppm}$ in some phosphate rocks, which have been considered as commercial sources of uranium (Clegg and Foley, 1958, NCRP, 1975).

As a result of the generally higher uranium concentrations in phosphate materials, the use of high phosphate fertilizers adds significantly to the level of uranium and its decay products in both the surface soils of agricultural areas and rain run-off from these soils. Consequently, produce grown with such fertilizers contains slightly elevated amounts of uranium. The average yearly human intake of uranium from all sources is about $0.7-1.4$ nanocuries $(1-2$ microgram of natural uranium) per day (Welford and B I, 1967, ICRP, 1979, Singh et al., 1990), with the majority of this coming from fruits and vegetables grown with phosphate fertilizers (Eisenbud, 1987). Inhaled ash from coal and oil-fired electrical generation plants was one of the major contributors to human dose prior to the first clean air legislation. Although this source has dropped since the late 1970s, it is still a minor contributor to the total yearly individual uranium dose (Eisenbud, 1987).

Uranium in surface water and ground water may be as high as several parts per million in some locations, but generally the concentrations are below $0.01 \mathrm{ppm}$ (Barker et al., 1965). For the Savannah River Site, the "average" background surface water concentration for uranium is approximately $10^{-5} \mathrm{ppm}$.

As part of the National Uranium Resources Evaluation (NURE) project in the 1970s, over 1000 well water samples were collected from the Augusta - Aiken area and throughout the area defined by the National Topographic Map Series (NTMS) Augusta $1^{\circ} \times 2^{\circ}$ quadrangle. The resultant average uranium concentration for this area (several thousand square miles) was $3.5 \times 10^{-4} \mathrm{ppm}$ with some levels as high as $0.03 \mathrm{ppm}$ (Jones, 1979).

There is no anthropogenic mechanism for the formation of uranium (as is the case of ${ }^{14} \mathrm{C}$ or ${ }^{129 / 1313} \mathrm{I}$ ). However, the very long half-lives of all of the major isotopes of uranium have ensured that the concentrations noted above will remain essentially constant over an extended period of time. Though the composition can vary widely depending on origin, the relative percentages of the major isotopes in natural uranium are approximately: ${ }^{238} \mathrm{U}-99.27 \%$, ${ }^{235} \mathrm{U}-0.72 \%$, and ${ }^{234} \mathrm{U}-0.0055 \%$.

For regulatory purposes, natural uranium is often treated as a chemical toxin rather than a radiological hazard. This is reflected in the fact that the interim drinking water limits for uranium concentration are given in parts per billion as opposed to activity per unit volume (40 CFR 141.15). Like most other heavy metals, uranium in very high concentrations may cause renal problems and, in general, the metal and its salts are quite toxic (Merck, 1983). 


\section{Uranium in the Savannah River Site Environment}

Releases of uranium have occurred at the Savannah River Site (SRS) since the start of the facility in the early fifties. These releases have generally been associated with the fabrication of reactor fuel and target elements (M Area), or the chemical processing of spent target and fuel material ( $F$ and $\mathrm{H}$ Areas). Releases have primarily been in the form of particulates into the atmosphere ( $\mathrm{F}, \mathrm{H}$, and $\mathrm{M}$ Areas), solution and particulates to the streams ( $M$ Area), and seepage basins ( $F, H, M$, and A Areas). Additionally, there have been some unplanned releases to streams, air, soil, and seepage basins. Because of the fairly low specific activity $\left(\sim 7 \times 10^{-7}\right.$ curies per gram) the released uranium does not constitute one of the major contributors to the SRS total environmental dose. The total quantity of uranium currently released from operational facilities is kept quite low $(\sim 0.2 \mathrm{~kg}$ per year from the $\mathrm{M}$ Area Liquid Effluent Treatment Facility) and has not been observed to migrate in any significant amounts after deposition in the immediate area of the initial release.
Unlike the natural isotopic distribution of uranium mentioned, the uranium currently used at the Savannah River Site is either enriched or depleted in ${ }^{235} \mathrm{U}$ relative to natural uranium. Uranium recovered from SRS processes may contain as little as $0.2 \%{ }^{235} \mathrm{U}$ and enriched material may be as high as $97 \%{ }^{235} \mathrm{U}$. For comparison, commercial power reactors normally use uranium that is $1.5 \%$ to $3.0 \%{ }^{235} \mathrm{U}$. In all cases the uranium used at SRS has been chemically purified. Because of the relatively long half-lives of the uranium isotopes, SRS uranium has undetectable amounts of the lower atomic-number decay products such as actinium, polonium, and radium that are present in natural uranium. All of these have been removed chemically and have not had time to grow back to a measurable degree. The lack of daughter products in uranium used in SRS processes make it possible to distinguish SRS releases from naturally occurring deposits of uranium in and around the site. 


\section{References}

Barker, F. B., J. O. Johnson, K. W. Edwards, and B. P. Robinson, 1965, Determination of Uranium in Natural Waters; U.S. Geological Survey Paper \#1696-C, U.S. Government Printing Office, Washington, DC.

Clegg, J. W. and D. D. Foley, 1958, Uranium Ore Processing; Addison-Wesley Press, Reading, Massachusetts.

Code of Federal Regulations, 1989, Interim Drinking Water Standards, 40-CFR-141.15.

Eisenbud, M., 1987, Environmental Radioactivity: From Natural, Industrial, and Military Sources., Third ed., Academic Press, Orlando, FL.

ICRP (International Commission on Radiological Protection), 1979, Limits for Intakes of Radionuclides by Workers, ICRP Publication 30, Part I, Annals of the ICRP.
Jones, P.L., 1979, Augusta $J^{\circ} \times 2^{\circ}$ NTMS Area Georgia and South Carolina: National Uranium Resource Evaluation Program; DPST-79-146-4, E.I. DuPont, Savannah River Site, Aiken, SC.

The Merck Index 12th ed., 1983, M. Windholz, S. Budavari, R. Blumetti, and E. Otterbein, eds., Merck \& Co., Inc., Rahway, NJ.

NCRP (National Council on Radiation Protection and Measurements), 1975, Natural Background Radiation in the United States. NCRP Report No. 45; Bethesda, MD.

Singh, N., D.P. Burleigh, H.M. Ruth, and M.E. Wrenn, 1990. Daily U Intake in Utah Residents from Food and Drit:ing Water, Health Phys. 59(3):333-337.

Welford, G.A., and R. Baird, 1967, Uranium Levels in Human Diets and Biological Materials, Health Phys. 13:1321-1324. 


\section{Chapter 2. Uranium Releases to the Environment}

Operations at SRS involve the use of uranium in both research and production areas. The isotopic composition may vary because uranium that has been either enriched or depleted in the ${ }^{235} \mathrm{U}$-isotope and natural uranium, which is native to the soil and water of the SRS, are present os the site. Uranium on the site is present in many chemical forms, such as the metallic uranium and uranium-aluminum alloy in fuel and target assemblies, various salts, such as uranyl nitrate or uranyl sulfate, present in the separations process streams, and metal oxides (principally $\mathrm{UO}_{3}$ and $\mathrm{U}_{3} \mathrm{O}_{8}$ ) produced at the end of the separations process. Small amounts of other chemical forms are present on the site for use in research work, primarily at the Savannah River Laboratory (SRL). Naturally occurring uranium is present in SRS soil and water principally as metal oxides.

Uranium releases have occurred principally from fuel fabrication and spent fuel processing facilities. Smaller releases have occurred from waste storage and research areas. These releases have occurred to the atmosphere, site streams, and the ground. The majority of these have been predicted releases resulting from such unavoidable situations as the natural imperfection of filtration media.

This Chapter describes the origins of documented uranium releases and their routes to the environment. These are releases that were anticipated and were measured either as uranium or as part of a gross-alpha measurement. 


\section{Specific Uranium Analyses and Unidentified Alpha}

Some SRS facilities that release uranium also release plutonium and other transuranic alpha emitting radionuclides. Specific radiochemical analyses for uranium were performed to distinguish uranium releases from releases of the more hazardous transuranium elements. In some facilities, where significant releases of alpha-emitting radionuclides were not anticipated, only gross-alpha (also called unidentified or unknown alpha) analyses were performed to provide an indication of the presence of unexpected alpha cmitters. The release tables in this Chapter indicate which values are derived from uraniumspecific radiochemical analyses and which were derived from gross-alpha analyses. In one facility, the SRL seepage basins, both analyses were performed over a 10 -year period.
However, no attempt was made to scale any data when dual analyses were not run because no consistent correlations between the data were found.

Most of the release data were taken from Cummins, Hetrick, and Martin, 1991, which summarizes SRS releases covering the period 1954 through 1989.

Releases of radioactivity are expressed in curies. To estimate the corresponding weight of released uranium, the specific activity for the given isotopic mixture must be calculated. For the "natural" uranium $\left(99.27 \%{ }^{238} \mathrm{U}, 0.72\right.$ " ${ }^{233} \mathrm{U}$, and $0.0055 \%{ }^{234} \mathrm{U}$ ), this specific activity 692 nanocuries per gram (3190 pounds/curie). 


\section{Releases From Separations Facilities}

The separations facilities ( $F$ and $H$ Areas) at SRS chemically purified the desired radionuclides that were produced in the reactors. These facilities, along with other DOE installations, also recycled the uranium used as reactor fuel. Therefore, both of these areas had the potential for releasing uranium.

Uranium releases to the environment occurred at the chemical separation facilities from the first days of operation. In the past, releases occurred to the atmosphere, to seepage basins, and, to a lesser extent, to plant streams. The basins were taken out of service in December 1988 and were stabilized and covered with a low permeability cap to reduce infiltration of contaminants to the groundwater. Monitoring of the groundwater near the old basins continues.

\section{F Area}

The F-Area facilities deal primarily with the isolation of ${ }^{239} \mathrm{Pu}$ from ${ }^{238} \mathrm{U}$ target material by the Purex process. Target slugs made of depleted uranium are stripped of their aluminum cladding and dissolved in nitric acid. The ${ }^{239} \mathrm{Pu}$ is then separated from the uranium by solvent extraction with $30 \%$ tributyl phosphate in n-paraffin solvent (Bebbington, 1990). Several stages of contactors and centrifugal separators are used to segregate the plutonium, fission and activation products, and the uranium into separate aqueous streams. The uranium is then converted from uranyl nitrate into ${ }^{238} \mathrm{UO}_{3}$, which is stored for future use.

\section{F-Area Releases to Atmosphere}

The main routes for uranium releases from this facility are through the process ventilation vents and the aqueous stripping streams. All process vessels are vented at the rate of $50 \mathrm{cfm}$ (Starks, 1977) in order to prevent chemical fumes and radioactivity from backing up into the main canyon area. The air is then routed through high efficiency particulate air (HEPA) filters and through large sand filters before being released through the main process stack. Air from other areas of the process is directly vented to the sand filter before being discharged from the stack. The sand filter removes $99.98 \%$ of the incident radioactive material. Air from a few remaining areas of the facility is sent through HEPA filters and then directed to the stack without passing through the sand filter (Starks, 1977). Offgas from the t. 'ine passes through bag filters before being discharged to the atmosphere. The Purex process has operated since 1954 except for 1957 and 1958 when new equipment was installed in the canyon buildings.

The atmospheric releases from the F-Area 291 stack are shown in Figure 2-1. The sharp drop-off in 1957-58 and the lower emission levels in 1959 and subsequent years are due to the modernization of the process equipment mentioned previously. During 1957 and 1958 there was no processing of uranium through the facility; however, the ventilation system continued to function. Production levels increased through the 1960 s reaching a maximum just before the end of the decade. Again, this is reflected in the emission rates. Subsequent to 1968 , lowered production has resulted in a much lower release rate. Also, since 1970, greater emphasis has been placed on lowering emissions because of the greater attention to environmental matters and the generally declining background radiation levels from nuclear fallout. If we assume that the two years, 1957 and 1958, when the facility was shut down represent the background values for the atmospheric release monitors, then the majority of the releases in recent years have been at background levels. Total releases of uranium from 1955 to 1988 from the 291-F stack are 0.648 curies. This translates to a yearly average release rate of 0.018 curies per year, which is comparable to the releases of uranium from a $250 \mathrm{MWe}$ coal-fired electrical power plant (Nakaoka et al., 1984).

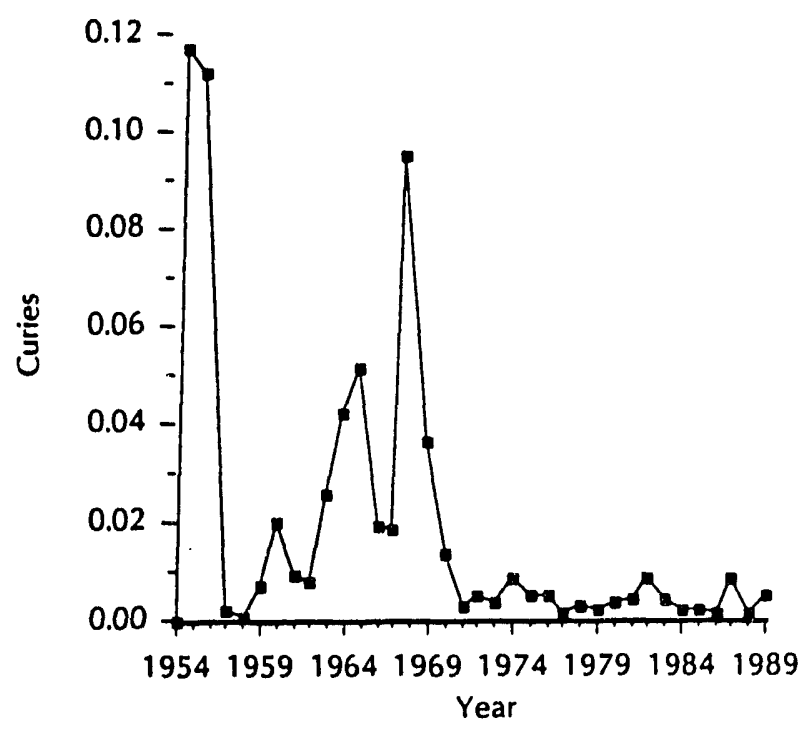

Figure 2-1. Uranium Releases to the Atmosphere, F Area 


\section{F-Area Releases to Seepage Basins}

Prior to late 1988, low-level radioactive liquid wastes were discharged to earthen seepage basins. Most of the radionuclides discharged to the seepage basins were either immobilized by complexation with the clays in the bottom and sides of the basin or moved slowly away from the basins in groundwater (some tritium and iodine volatilized from the basin to the atmosphere). Tritium and ${ }^{129}$ I move away from the basins at essentially the same speed as the groundwater. Use of the seepage basins was discontinued in 1988 and the low-level liquid wastes are now processed in the Effluent Treatment Faci'ity (ETF). In ETF all radionuclides, except tritium, are removed from the waste water and entombed in saltcrete in a similar fashion as the decontaminated salts anticipated from the Defense Waste Processing Facility (DWPF). The decontaminated water exiting ETF is discharged to Upper Three Runs Creek.

Aqueous high level waste streams and the exhausted aqueous process streams are concentrated by use of steam heated evaporators. After removal of the water, the concentrated waste stream proceeds to the high-level waste tank farm for storage until DWPF is functional. The condensate from the evaporators passes through a roughing filter and, from 1955-1988, went to the seepage basins as indicated above. Though this waste stream is primarily condensed steam, it is contaminated by small amounts of volatile elements such as cesium and iodine. Because of spattering in the evaporator, some uranium is also present in the condensate waste stream. Additional routine sources of waste water formerly discharged to seepage basins include process drains. Some process cooling water has also been routed to the seepage basins when evaporator cooling coil leaks occurred.

Figure 2-2 shows the releases to the F-Area seepage basin system from 1955 to 1988 , when the releases were stopped. Though there are no strong correlations to production rates, which were seen in the atmospheric release data, there have generally been lower yearly releases since 1970 .

\section{F-Area Releases to Streams}

Cooling water for portions of the F-Area separation process line is pumped from deep wells and discharged to Four Mile Creek after use. This water has been used either in the "once through" or the "segregated" cooling water systems used to control temperatures in the separations process. Because of the possibility of a cooling coil leakage, these cooling water streams have the potential to contain measurable amounts of radioactivity. Cooling coils are used in the head end

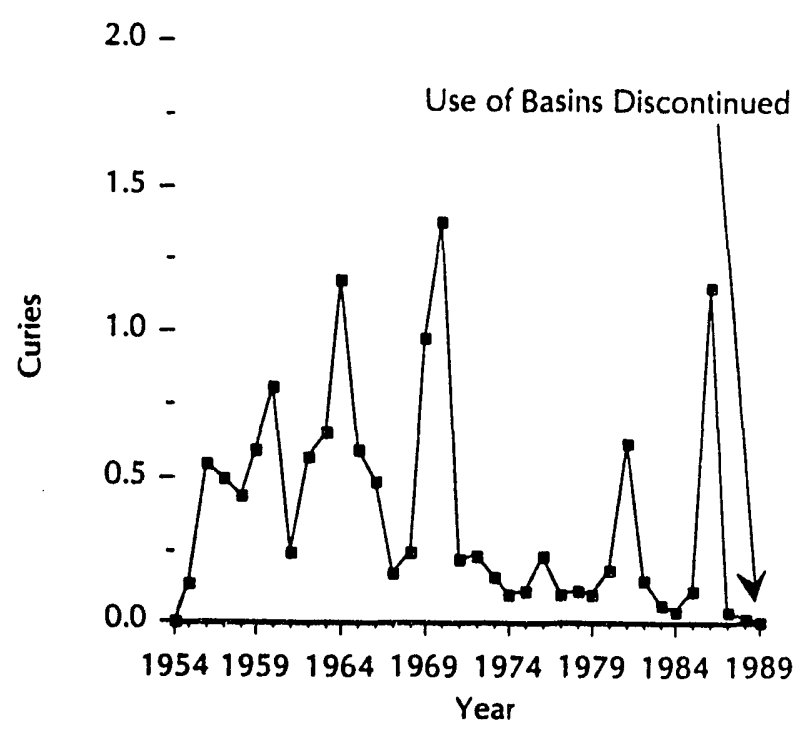

Figure 2-2. Uranium Releases to Seepage Basins, F Area

dissolvers, which provide a mixture of many fission and activation products as a potential contaminant of the cooling system. Uranium is a predominant chemical constituent of this mixture, but the majority of the alpha activity is due to the transuranic activation products.

In order to minimize releases of radioactivity into the cooling system when a leak does occur, positive pressure is maintained in the cooling coils in all process vessels. After the water has been used, it is monitored and released into Four Mile Cieek. Should activity levels in the water preclude the discharge of the water to the creek, the contaminated water is held in a plastic-lined diversion basin and transferred to either the H-Area waste tank farm, or it is sent to ETF for cleaning. In the past, water in the diversion basin that was too radioactive for release to the stream was pumped to the seepage basins as indicated in the previous section.

Radioactivity levels are measured slightly downstream from the release from the F-Area cooling system. Specific radiochemical analyses for uranium and plutonium are not made on water discharged from the segregated cooling water system. Because the cooling water used in the process is pumped from deep wells drawing from the Middendorf aquifer (as is the drinking water for $F$ Area), a portion of the activity measured at the outfall is present before use due to trace amounts of natural radioactivity in the well water. The natural background activity of the cooling water is not measured, but can be inferred by examining the activity measured in drinking water samples. The data on gross alpha activity found in F-Area drinking water samples in 1989 are summarized in Table 2-1 (Cummins, Martin, and 
Table 2-1. Gross Alpha Activity in F-Area Drinking Water, 1989

$\begin{array}{lcccc}\begin{array}{c}\text { Sample } \\ \text { Location }\end{array} & \begin{array}{c}\text { No. } \\ \text { Samples }\end{array} & \begin{array}{c}\text { Max Conc } \\ \text { pCi/L }\end{array} & \begin{array}{c}\text { Min Conc } \\ \text { pCi/L }\end{array} & \begin{array}{c}\text { Annual } \\ \text { Average, pCi/L }\end{array} \\ 221-\mathrm{F} & 13 & 12.4 & 0.78 & 4.40 \pm 3.37^{*} \\ 701-1 \mathrm{~F} & 4 & 7.47 & 1.90 & 3.85 \pm 2.47^{*} \\ 704-\mathrm{F} & 5 & 5.09 & 1.47 & 3.26 \pm 1.29^{*} \\ 772-\mathrm{F} & 5 & 7.09 & 1.24 & 4.41 \pm 2.60^{*} \\ & & & \text { Overall Average } & 3.98 \pm 5.08 \dagger\end{array}$

- The error value listed is the standard deviation (1o error)

+ The error value listed was calculated using the propagation of errors method

Todd, 1990) and are typical of values obtained in prior years.

An estimate of the average gross alpha concentration in cooling water can be obtained by dividing the annual release (curies) by the annual total flow (liters) listed in Cummins, Hetrick, and Martin (1991). The resulting range of values obtained for the period 1954-1988 was $6.87 \mathrm{pCi} / \mathrm{L}$ to $19.61 \mathrm{pCi} / \mathrm{L}$ with an average of $3.18 \pm 3.94 \mathrm{pCi} / \mathrm{L}$. This average is not significantly different from the average drinking water concentration in F Area in 1989. This suggests that the gross alpha activity discharged in F-Area cooling water is primarily the naturally occurring activity found in the well water from which the cooling water is derived.

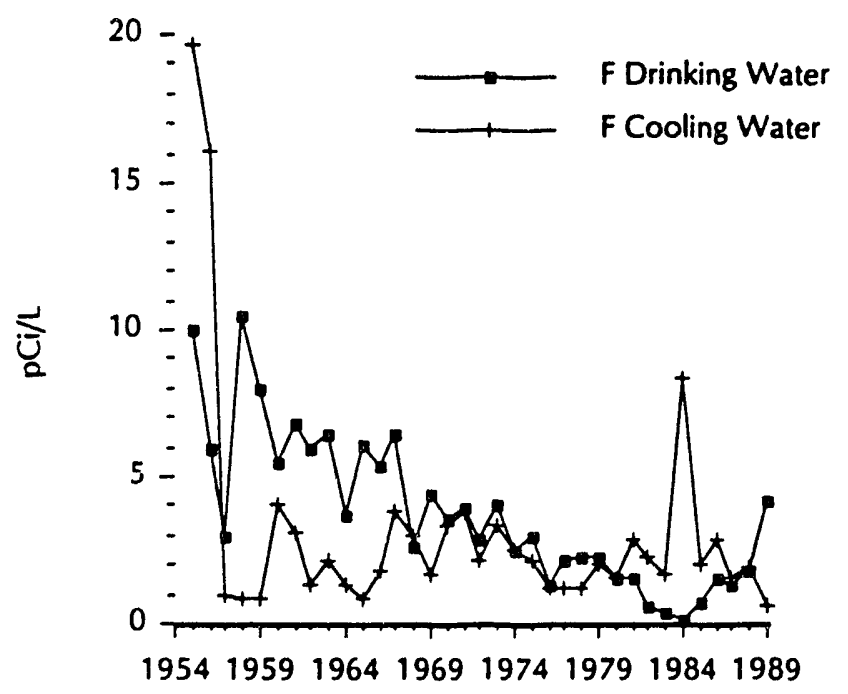

Figure 2.3. Gross Alpha Activity in Drinking Water and Cooling Water, F Area
A plot of gross alpha activity in the drinking water and cooling water from $F$ Area confirms that the two are equivalent except during periods of known cooling coil leaks as shown in Figure 2-3. Leaks occurred in cooling coils in 1955, 1956, and 1984.

Annual releases to Four Mile Creek are shown in Figure 2-4. As noted previously, the uncorrected "unidentified alpha" levels must be used to estimate the possible uranium releases to the stream. No corrections are made to the "unidentified alpha" data because in most cases the drinking water data agree with the release data. For the following described incidents or process equipment failures, isotopic analyses would have been helpful but were not performed. The high releases in 1955 and 1956 were associated with evaporator coil leaks. Alpha spectrometry measurements on a few samples taken in late 1955 attributed the predominant

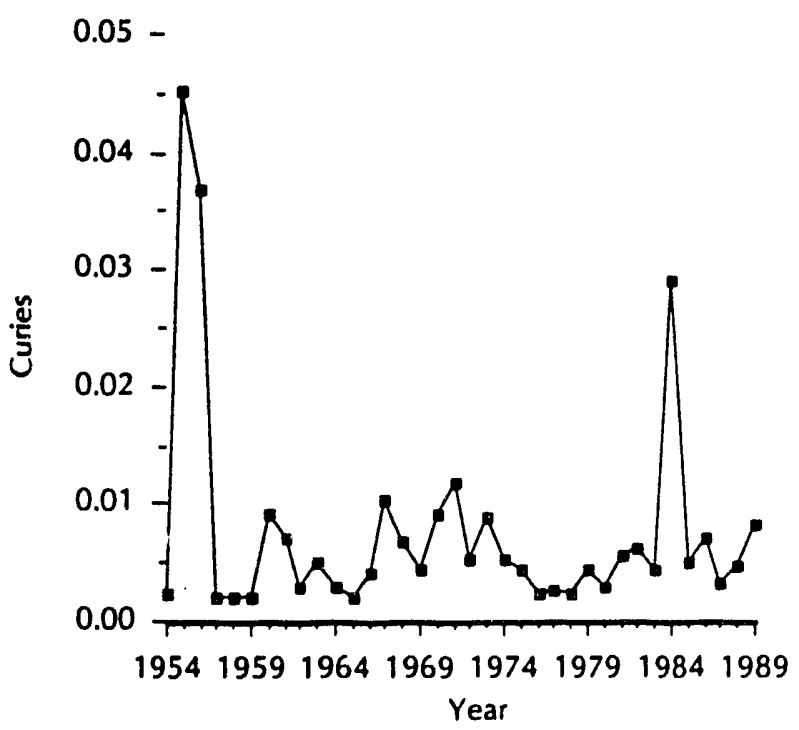

Figure 2-4. Gross alpha Releases to Streams, F Area 
activity to $U^{238}$, but the presence of plutonium cannot be ruled out. The 1984 release resulted from run-off to the storm sewer system from the uranium recovery facilities (A-Line). The 1984 release was probably predominantly depleted uranium.

\section{H Area}

Enriched uranium fuel elements are processed in the 221-H canyon building using the HM process. This process is similar to the Purex process except that a mercury catalyst is used in order to facilitate the controlled dissolution of the uranium-aluminum alloy used for fuel fabrication. The HM process was designed primarily to recover ${ }^{235} \mathrm{U}$ from enriched fuels that are used in the SRS reactors. Some used fuels from other sources are also processed in $\mathrm{H}$ Area. Fuel elements processed in $\mathrm{H}$ Area contain from $1.1 \%$ to $94 \%$ ${ }^{235} \mathrm{U}$ (Hyder et al., 1979). The higher enrichments were in those fuels used at SRS, and the lower enriched fuels were used at other DOE sites.

Even after a complete irradiation in the reactors, most of ${ }^{235} \mathrm{U}$ remains in the fuel elements. Therefore, recovery and recycle of the unburned ${ }^{233} \mathrm{U}$ from fission and activation is highly desirable.

For SRS fuels, the enriched uranium is segregated from the undesired materials and a critically safe, dilute solution is shipped offsite for reduction to uranium metal. The resulting metal is returned to SRS for incorporation into new fuel for the reactors. The dilute solutions resulting from processing slightly enriched fuels from other DOE facilities are also shipped offsite for recycling of the fissile material.

\section{H-Area Releases to Atmosphere}

The atmospheric venting system of the H-Area facilities is similar to $F$ Area. All ventilation air passes through either the sand filter, HEPA filters, fiberglass particulate filters, or a combination of these filters.

The yearly releases of uranium from the $291-\mathrm{H}$ stack are shown in Figure 2-5. In contrast to the data from F Area, the pre- and post-1970 data are not markedly different. There was a trend towards lower emission levels in later years as the total amount of material processed at the facility also declined. The total atmospheric release of uranium for the lifetime of the facility through 1989 is 0.286 curies.

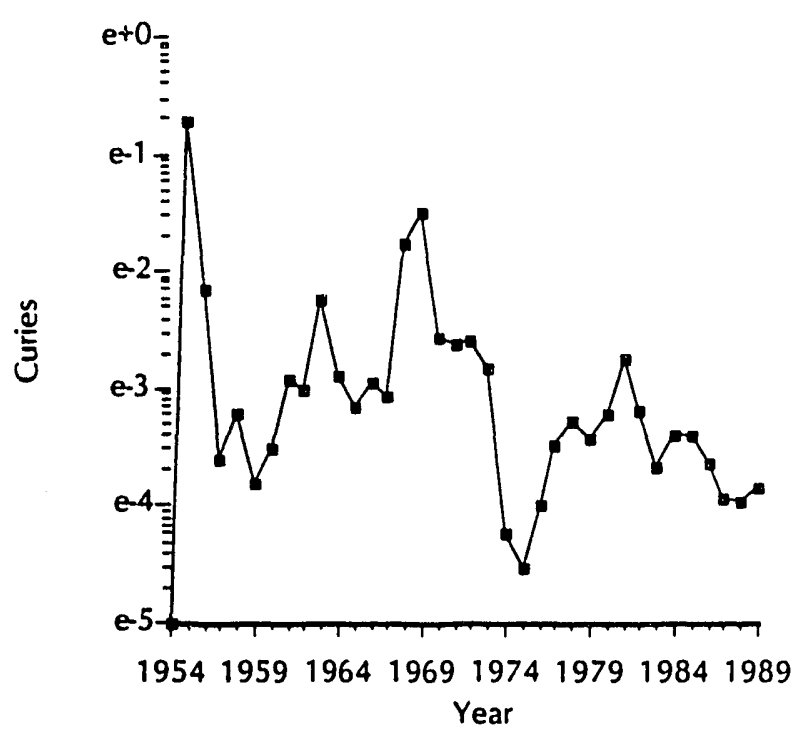

Figure 2-5. Uranium Releases to the Atmosphere, H Area

\section{H-Area Releases to Seepage Basins}

As with F Area, the evaporator overheads and run-off from some portions of the drainage system were directed into seepage basins prior to 1988. The specific sources for the evaporator feeds to the seepage basins were the head end evaporator, low-level segregated waste, low-activity rerun waste, segregated solvent recycle sump, gang valve corridor sumps, water handling waste and A-line sumps. All of these are classified as low- or no-activity waste streams and are sent to the general purpose evaporator. In this evaporator the volume of the feed streams is reduced and the condensate from the evaporator was directed to the seepage basins. Again, volatile radionuclides such as cesium and iodine would have passed through the evaporator had they been present. If spattering of the feed stream occurred during evaporation, there could have been carry-over of the other elements as well. Figure 2-6 shows the releases of uranium to the $\mathrm{H}$-Area seepage basins from startup until the cessation of their use in 1988. As with the previous graphs, releases during the lifetime of the basin have declined with reduced roduction and better retention of waste materials. The total lifetime recorded uranium release through 1988 for $\mathrm{H}$-Area to these basins is 1.421 curies of uranium. 


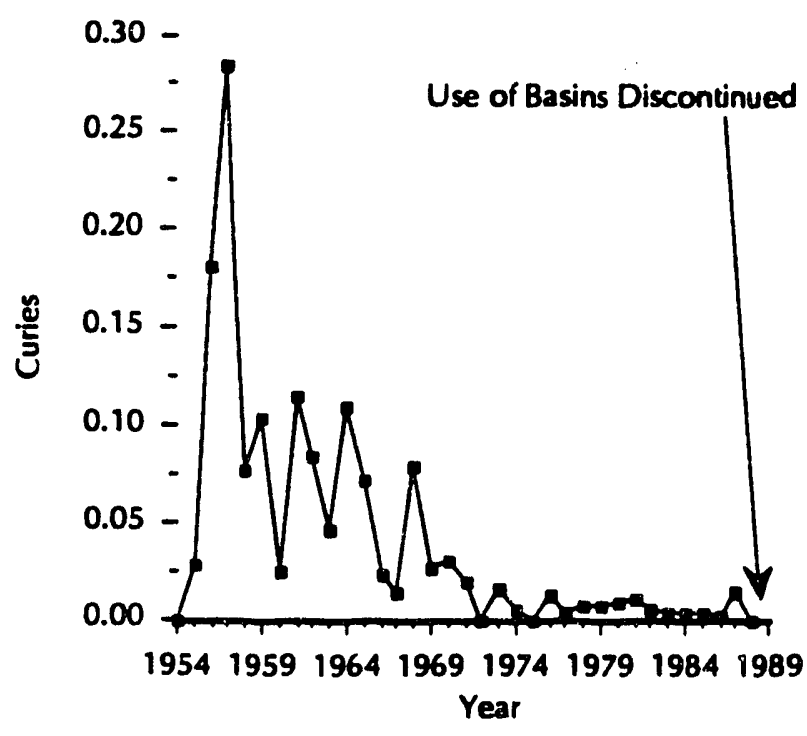

Figure 2-6. Uranium Releases to Seepage Basins, H Area

\section{H-Area Releases to Streams}

As with F Area, portions of the H-Area process equipment are cooled with water derived from deep wells. After use, the cooling water is monitored and discharged into Four Mile Creek. Figure 2-7 shows the estimated uranium releases from $H$ Area based on unmodified, unidentified alpha data. The comparison between effluent monitoring data are in fairly close agreement with the drinking water data. Drinking water data for 1989 are shown in Table 2-2. The range of values of annual average concentrations obtained from release data was $0.77-10.75 \mathrm{pCi} / \mathrm{L}$, with an average of $4.05 \pm 2.84 \mathrm{pCi} / \mathrm{L}$ for the period 1955-1988 (H Area did not begin operations until 1955).

A plot (Figure 2-8) of gross alpha activity in the drinking water and cooling water from $H$ Area confirms that the two are equivalent except during periods of known cooling coil leaks.

Table 2-2. Gross Alpha Activity in H-Area Drinking Water, 1989

\begin{tabular}{lcccc}
$\begin{array}{l}\text { Sample } \\
\text { Location }\end{array}$ & $\begin{array}{c}\text { No. } \\
\text { Samples }\end{array}$ & $\begin{array}{c}\text { Max Conc } \\
\text { pCi/L }\end{array}$ & $\begin{array}{c}\text { Min Conc } \\
\text { pCi/L }\end{array}$ & $\begin{array}{c}\text { Annual } \\
\text { Average. pCi/L }\end{array}$ \\
$221-\mathrm{H}$ & 14 & & & \\
$701-1 \mathrm{H}$ & 5 & 5.74 & 0.94 & $3.04 \pm 1.53^{*}$ \\
$704-\mathrm{H}$ & 5 & 3.77 & 1.91 & $2.68 \pm 0.73^{*}$ \\
& & 4.48 & 1.02 & $2.91 \pm 1.41^{*}$ \\
& & \multicolumn{2}{c}{ Overall Average } & $2.88 \pm 2.20+$
\end{tabular}

- The error value listed is the standard deviation (10 error)

t The error value listed was calculated using the propagation of errors method

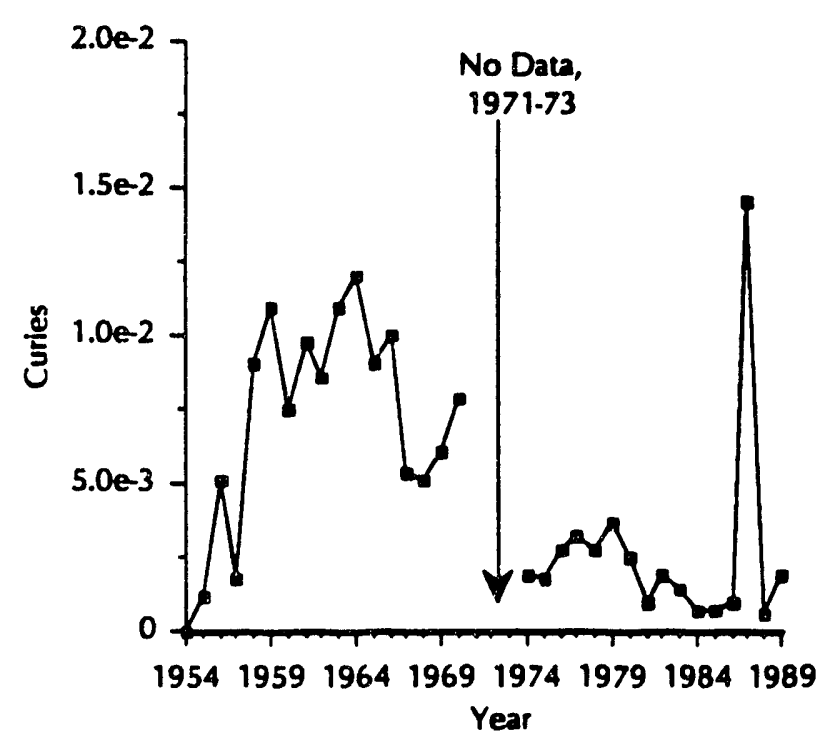

Figure 2-7. Gross alpha Releases to Streams, H Area

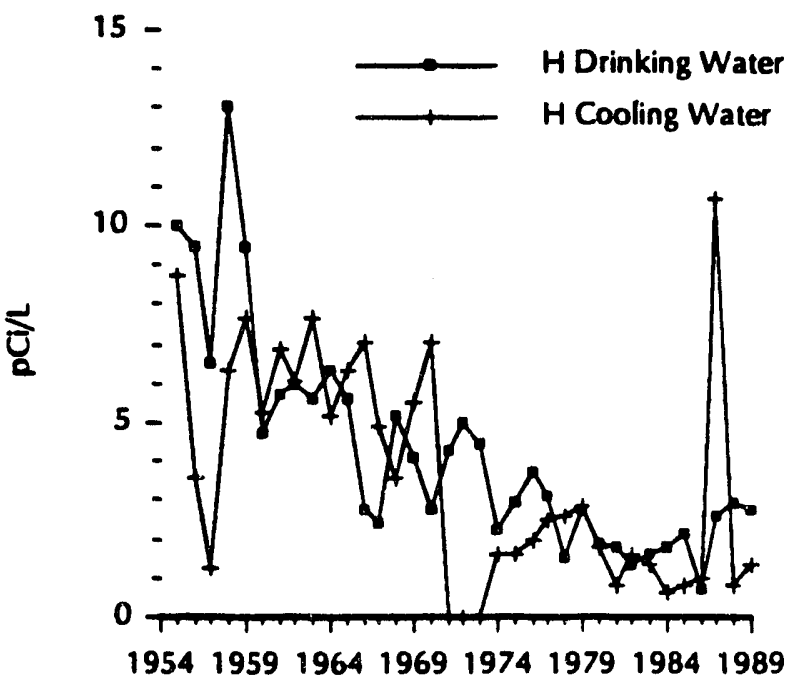

Figure 2-8. Gross Alpha Activity in Drinking Water and Cooling Water, $\mathrm{H}$ Area 


\section{Releases From Fuel Fabrication Facilities}

Fuel and target assemblies used in the SRS reactors are fabricated onsite from aluminum and uranium metal. These assemblies are produced in the M Area facilities and employ machining of uranium and cladding of uranium with aluminum. Machining of the uranium metal pieces is carried out in a fashion similar to typical machining of any metal part while the cladding is accomplished by the use of dip-canning or press swaging of the aluminum around the uranium cores of the fuel and target elements (Bebbington, 1990). In a separate process, enriched uranium fuel tubes are manufactured by first alloying the uranium with aluminum metal. After machining, the cast alloy billets are coextruded with pure aluminum to form the active core of the fuel assemblies. The production of uranium fuel and target elements is accompanied by generation of metal fines, filings, and dust. Other processes in the manufacture of fuel and target elements result in uranium being dissolved or suspended in solutions. The majority of these materials are caught and returned to the process, but some losses do occur.

Releases of uranium from $M$ Area to the environment have occurred in three forms; stack releases to the atmosp/iere, liquid releases to the seepage basin system, and liquid releases to Steed Pond and Tims Branch.

\section{M-Area Releases to Atmosphere}

Though activity release alarms were in place on building exhausts from the first days of operation, chronic atmospheric releases from $M$ Area were not measured prior to 1975. However, even the highest recorded yearly release was only 0.0001 curies. The recorded releases from the M-Area stacks are shown in Figure 2-9. While there is no definitive pattern to the releases here, it should be noted that the highest recorded atmospheric release was nearly 10,000 times less than the peak atmospheric releases from F Area. The total recorded release of uranium from 1975 to 1989 is $1.7 \times 10^{-4}$.curies. This is the equivalent of about $80 \mathrm{~g}$ of natural and depleted uranium during the time of the measurements or, roughly, $6 \mathrm{mg} /$ day

\section{M-Area Releases to Streams}

The largest releases of uranium onsite have occurred from the M Area to Tims Branch, one of the onsite tributaries of the Savannah River. During the target machining and cladding process, several steps take place that have the potential of putting uranium in solution.

The uranium target slugs themselves are surface etched with acid to provide a better bonding site for the cladding; consequently, this etching solution contains up to $300 \mathrm{~g} / \mathrm{L}$ of uranium. After cladding, the aluminum seals on the uranium slugs are tested by autoclaving the slugs. If any leaks are present in the cladding, slug rupture will occur as a result of reaction of the steam with the uranium. This rupture is visible and the slugs can then be rejected. In the event that slugs do rupture, the wash-down water of the autoclave contains particulate uranium oxide.

The rejected aluminum clad slugs have the aluminum and nickel cladding removed in a sequential set of tanks-the first containing sodium hydroxide and the second nitric acid. Though the sodium hydroxide does not affect the uranium, the nitric acid dissolves some of the uranium in the process of removing the nickel coating on the uranium. The liquid streams resulting from these processes were formerly treated by precipitating as much of the dissolved material as possible and then filtering the solution to remove the suspended solids.

In the past, overflow containing low concentrations of uranium from several points in this system was discharged to the facility sewer system, and some of the outflow

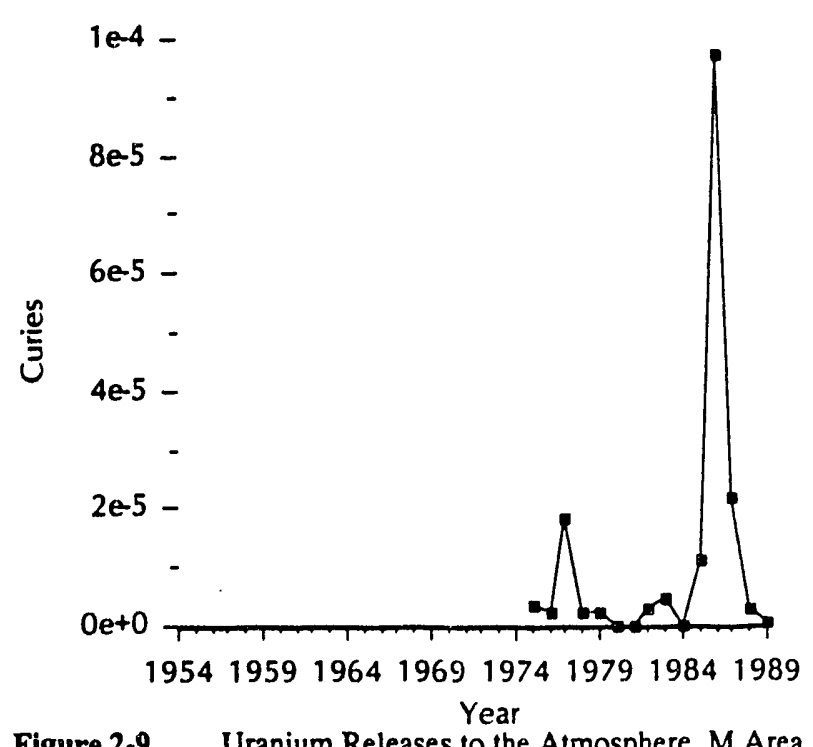

Figure 2.9. Uranium Releases to the Atmosphere, M Area 


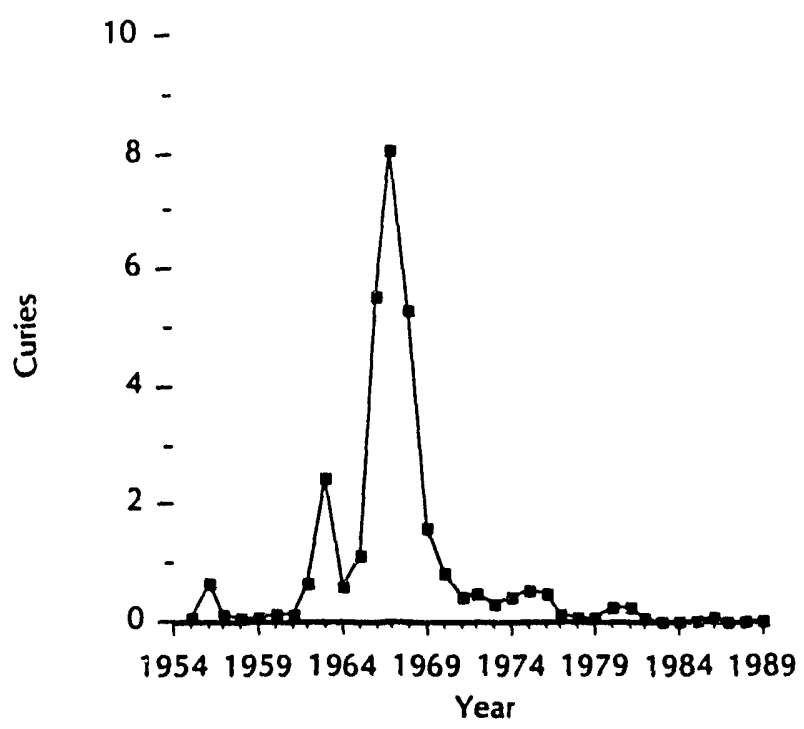

Figure 2-10. Uranium Releases to Streams, M Area

eventually reached the area surface water discharge system. The direct release of drain water from the uranium target production facility in M Area, was terminated in 1973 when the process sewer discharges were diverted to the M-Area settling basin.

Uranium-aluminum alloy fuel production takes place in Building 321-M. There is less handling and treatment of unalloyed uranium metal in this process so there are far lower releases of uranium. The initial alloying of ${ }^{235} \mathrm{U}$ enriched uranium with aluminum is followed by extrusion cladding of the alloy with an additional layer of aluminum.

Only the aluminum cladding is chemically cleaned. Floor mop water, from housekeeping in the uranium-aluminum alloy casting and machining room and from 322-M metallurgical laboratory in which samples of the fuel tubes are exarnined, was discharged to a process sewer. This sewer discharged to a settling basin that was specifically constructed to prevent discharges of wastewater containing trace quantities of enriched uranium from being released to surface streams. Overflow from the settling basin subsequently occurred to a surface depression called Lost Lake, which has no surface outlet.

Both Building 321-M and the settling basin were constructed in 1958. This settling basin was used for additional process sewer releases and will be discussed later in this section.

Significant releases to Tims Branch waters ended in 1979 with the diversion of the primary uranium release streams to the settling basin. All releases of untreated process waste water were diverted to the settling basin in May 1982.
The measured M-Area releases to surface streams from 1955-1988 are shown in Figure 2-10. As might be expected from production history, the peak release years occurred in the late 1960 s and early 1970 s with releases declining since that time. The total recorded uranium release is 24.7 curies. While this is a significant amount of depleted uranium, stream sediment studies (discussed in Chapter 3) have shown that the uranium is immobilized and is not migrating into the Savannah River. Elevated levels of other products of the fuel production process, such as chromium, lead, nickel, and thorium, have also been observed, but, like the uranium, these are bound in the stream sediments. (Pickett and McDowell, 1990)

\section{M-Area Releases to Seepage Basin}

The M-Area settling basin operation began in 1958 with the construction of a settling basin for the retention of enriched uranium released to the process sewer from 321-M. After two years of operation, the settling basin began to overflow into Lost Lake.

In 1973, the effluent from 313-M (uranium target elements) was diverted to the settling basin system, and, in 1979, other significant process effluents containing uranium were diverted from Tims Branch to the M-Area settling basin. In 1982 all process effluents were diverted to the basin. All use of the settling basin system ceased in 1985 when the M-Area Liquid Effluent Treatment Facility (LETF) became operational. Wastes recovered from the LETF are being stored prior to entombment in saltstone in Y Area.

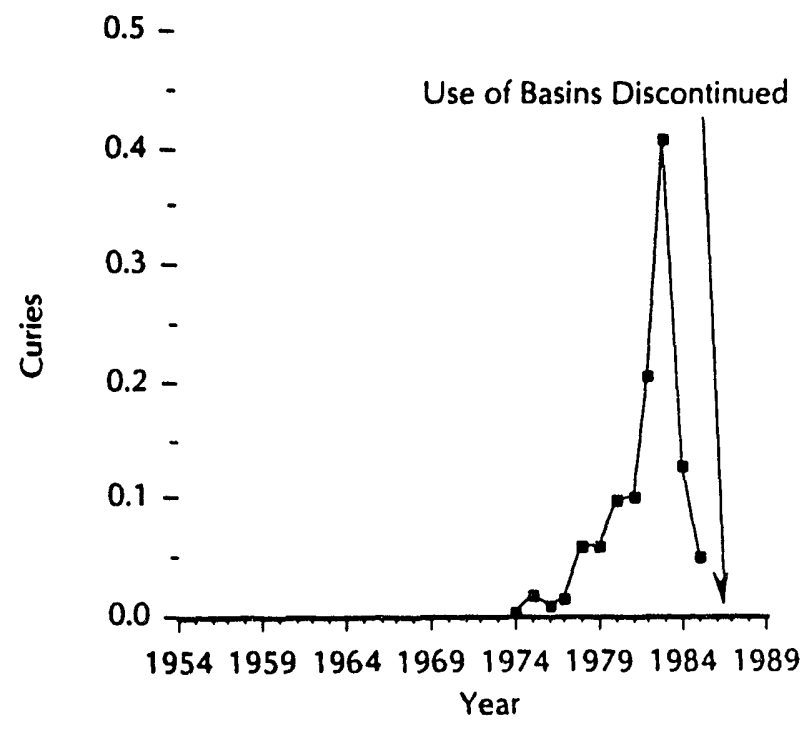

Figure 2-11. Uranium Releases to Seepage Basins, M Arca 
This page left intentionally blank. 


\section{Releases From Savannah River Laboratory Area}

Though not a part of the immediate production process, the Savannah River Laboratory (SRL) performs analysis of process samples for the plant portion of the site and conducts research in areas that involve the use of uranium and uranium compounds. The exhaust from the high-level hot cells or "caves", laboratory hood exhaust, and liquid trade waste are all possible routes for release of uranium to the environment from SRL. The majority of the releases from SRL have a low enough total activity that there is no measurement of uranium as a separate species. These releases were monitored as gross alpha, as indicated in the discussion early in this Chapter.

\section{SRL Releases to Atmosphere}

During its existence, SRL has performed numerous analyses of fuel and target material, and it has also dealt with ${ }^{238} \mathrm{Pu}$, isotopes of americium, curium, californium, and many other transuranics with high specific alpha activities. The amount of these materials is small relative to the mass of uranium handled in the facilities, but they could easily account for the majority of the alpha activity recorded. For that reason the conversion of the alpha levels to uranium by the use of a simple ratio is unwarranted.

The main ventilation stack from SRL handles the ventilation of the laboratory hoods, the hot hoods and the high-level hot cells. While all ventilation air now passes through a sand filter, some of the ventilation streams pass first through HEPA filters, charcoal filters, caustic scrubbers, or a combination of these filters prior to reaching the sand filter.

The historic atmospheric re'eases of alpha activity from the SRL stack are shown in Figure 2-12 and Table 2-3 (see page 2-22). If the total unidentified alpha activity releases for this period are assumed to be uranium releases, this would be the equivalent of $2.62 \times 10^{-3}$ curies of uranium over the lifetime of the facility. Again, as most of the materials used in the research areas of SRS have far higher, specific activities and shorter half-lives than uranium, this should be considered an upper limit value, and the true releases of uranium may be lower by orders of magnitude. Elevated releases observed during the period 1968-1971 coincided with the processing of ${ }^{237} \mathrm{~Np}$, ${ }^{24} \mathrm{Cm}$, and ${ }^{252} \mathrm{Cf}$ in SRL facilities. Thus, much of the activity released was probably not uranium.

\section{SRL Releases to Seepage Basins}

Prior to 1982 a series of four basins south of the technical area was used for the disposal of low-level radioactive waste from buildings 773-A and 735-A. As with the seepage basins in the production areas, the effluent stream was allowed to settle in the first three basins and overflow into the fourth basin from which there is no surface overflow. In this final basin, the clays lining the basin formed complexes with the majority of the radionuclides and prevented their migration into the groundwater system.

From 1972 to 1982, uranium was measured as a separate chemical species in the effluent to this basin. Prior to 1972 , only unknown alpha was measured in addition to a few nuclides of interest. The same ${ }^{2 \cdot 37} \mathrm{~Np},{ }^{244} \mathrm{Cm}$, and ${ }^{252} \mathrm{Cf}$ processing campaigns that contributed to the increases in atmospheric releases also contributed to increases in seepage basin releases. Owing to changes in the research programs conducted there, the composition of the effluent from SRL changes to a much greater extent than waste streams in the productinn 'acilities.

During the period 1973-1982, both gross alpha and specific uranium measurements were made on discharges to the SRL basins. The total measured uranium release for the period

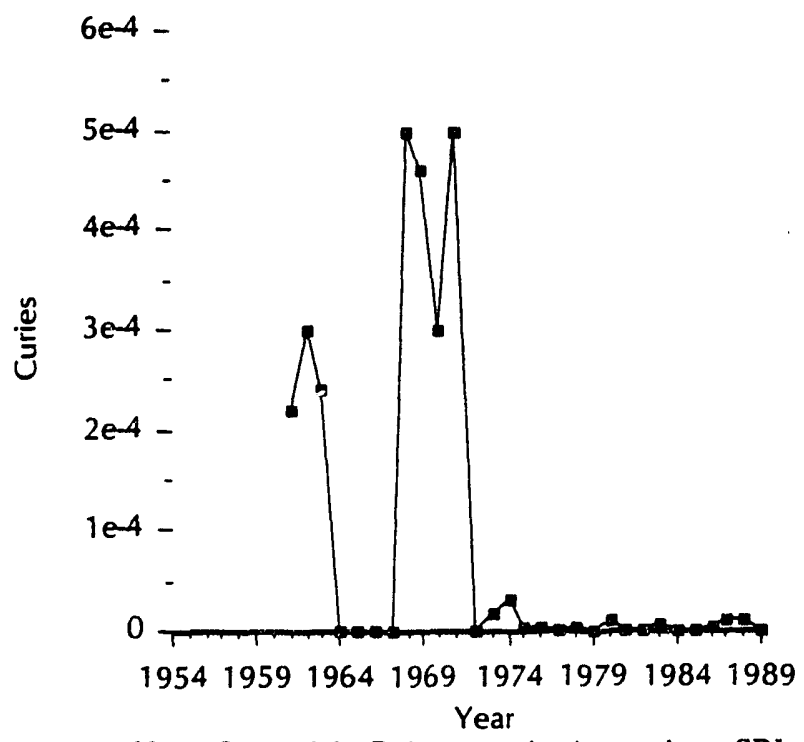

Fig ure 2-12. Gross alpha Releases to the Atmosphere, SRL 


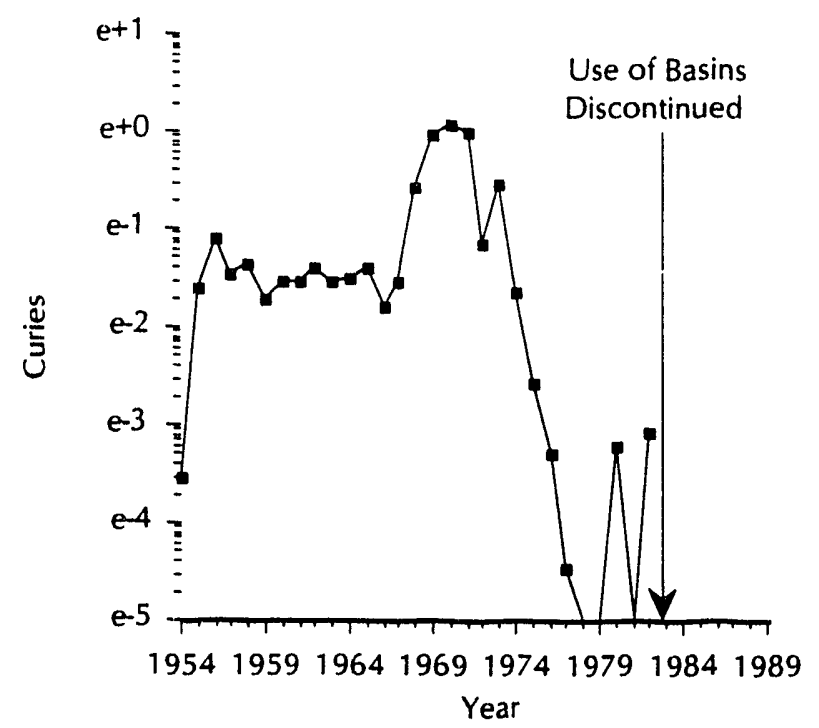

Figure 2-13. Gross Alpha Releases to Seepage Basins, SRL

was $21.98 \mathrm{mCi}$ while the gross alpha results indicated a total release of $327 \mathrm{mCi}$ of activity. Thus, for this period only $6.7 \%$ of the activity released was due to uranium. The historic gross alpha releases to the SRL basin system are shown in Figure 2-13; the recorded uranium releases are shown in Figure 2-14. Total releases of alpha emitters for

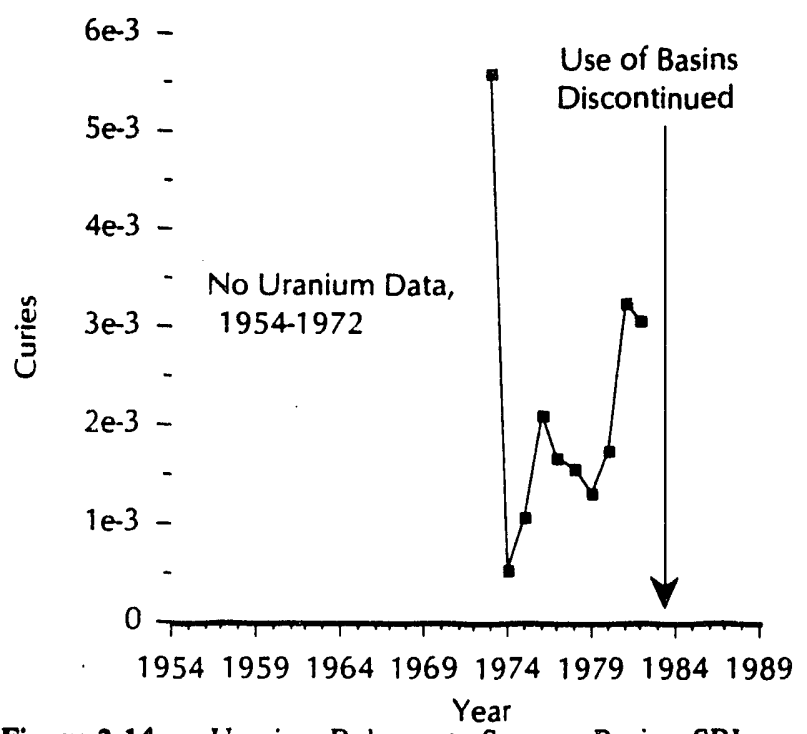

Figure 2-14. Uranium Releases to Seepage Basins, SRL

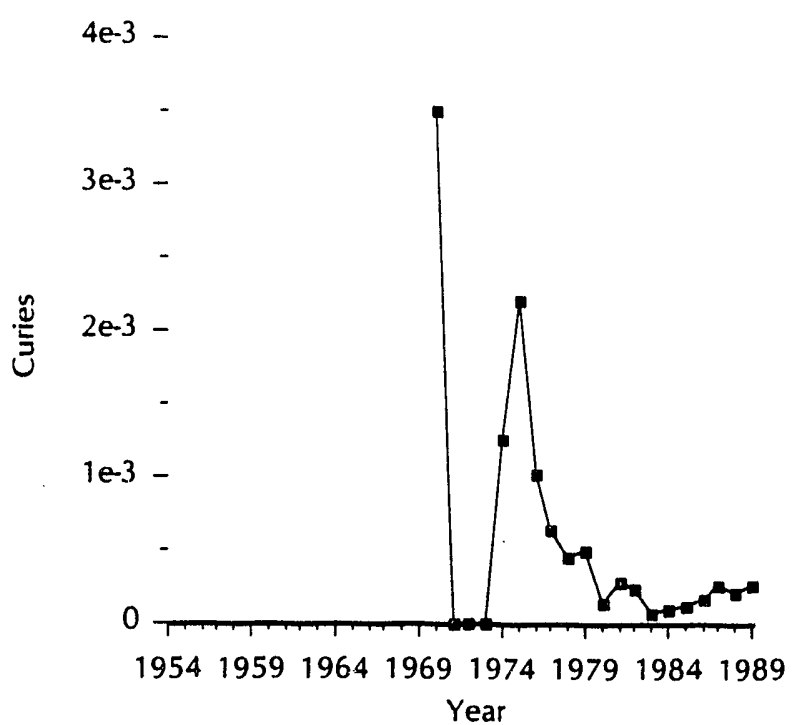

Figure 2-15. Gross alpha Releases to Streams, SRL

the lifetime of the basins (1954-1982) were 4.165 $\mathrm{Ci}$ based on the gross analyses. Considering that $3.318 \mathrm{Ci}$ of this total was released from 1968 to 1971 when known ${ }^{237} \mathrm{~Np},{ }^{244} \mathrm{Cm}$, and ${ }^{252} \mathrm{Cf}$ processing campaigns were in progress, it is unlikely that uranium releases exceeded $1 \mathrm{Ci}$ during the lifetime of the basins.

\section{SRL Releases to Streams}

Liquids from trade waste drains, some laboratory sinks, storm drains and some floor sumps are released to a small stream to the south of SRL. This stream runs into Tims Branch, which runs into Upper Three Runs Creek. Typically, this effluent contains some chemical waste. In spite of the segregation of waste streams, some activity does get into this effluent stream. Administrative controls have been instituted to reduce the amount of material released through this route. Figure 2-15 and Table 2-3 show the effects of this control with the steadily declining releases. No monitoring data are available prior to 1970 . The maximum possible uranium activity released through this route is $5.85 \times 10^{-3}$ curies during the period when there was active monitoring (1970-1989). 


\section{Releases From CMX/TNX}

The CMX/TNX area of SRS is a facility devoted primarily to pilot plant testing of various engineering aspects of the plutonium and tritium production processes. In the last several years, significant work has been done at TNX in the development of waste vitrification systems for containment of high-level wastes. Various fuel and target fabrication

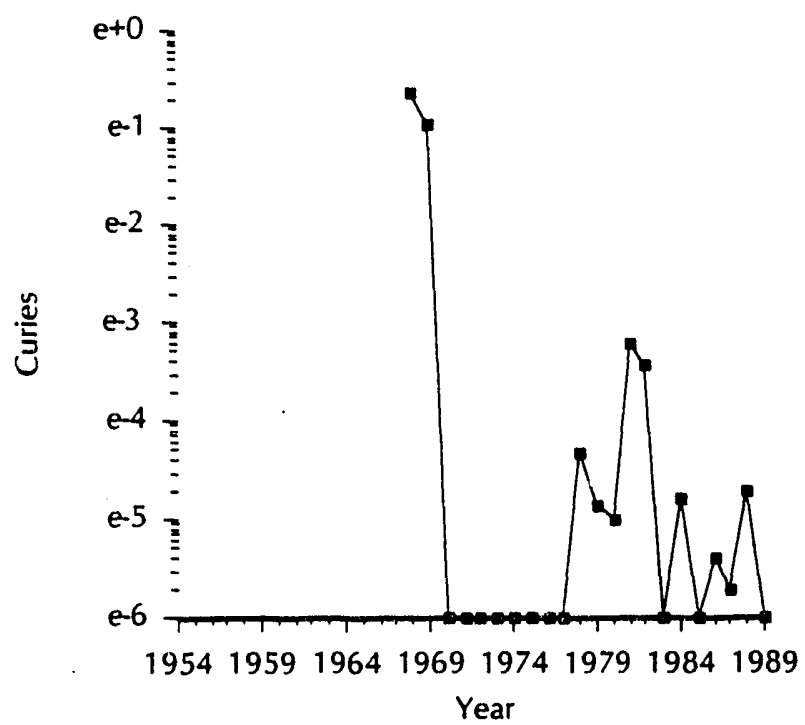

Figure 2-16. Gross Alpha Releases to Seepage Basins, TNX CMX equipment has also been developed and tested at TNX. The majority of these tests were performed with "cold" material, but some natural uranium was used in the fuel and taiget development work.

The only planned releases of uranium at the CMX/TNX facilities were to a seepage basin. These releases are shown in Figure 2-16 and Table 2-3 (see page 2-25). Fuel development took place in 1968-69, and it is likely that either releases to the seepage basin were not monitored or: the monitoring equipment was not sensitive enough to detect the very small continuing releases until the next year in which a value is shown -1978 .

In addition to the planned releases, approximately $454 \mathrm{~kg}$ of uranyl nitrate solution (natural uranium) was released to the CMX building and environs in January 1953 as a result of a prototype evaporator explosion. A trench was excavated in the field outside the building and all the decontamination solutions and materials used in the decontamination effort were buried in the trench (known as the TNX burying ground). An estimated $315 \mathrm{mCi}$ of natural uranium was buried at this location. From 1980-1984, much of the waste material at the TNX burying ground was excavated and relocated to the SRS waste burial grounds located between $F$ and $\mathrm{H}$ Areas. An estimated $27 \mathrm{~kg}$ of uranyl nitrate remains buried at TNX. 


\section{Releases From Reactor Areas}

Five reactors, designated $P, K, L, C$, and $R$, were originally built at SRS to produce tritium, plutonium, and other radionuclides useful for medical, research, or power applications. The level of reactor operation has been dependent upon the need for plutonium and tritium for national defense purposes. Thus R Area operated for approximately 11 years from 1954 through 1964 and was then shut down, decommissioned, and, eventually, used for parts. L Reactor was shut down and placed on standby from 1969 through 1981. Extensive modifications were made in L Area in 1981 to bring the reactor and its support facilities in line with continuing upgrades that had been ongoing during the operation of $\mathrm{P}, \mathrm{K}$, and $\mathrm{C}$ Reactors. L Area restarted at reduced power in 1985. C Reactor has been mothballed since 1987 owing to the discovery of microscopic cracks in some welds in the reactor tank wall. The remaining three operational reactors- $\mathrm{K}, \mathrm{L}$ and $\mathrm{P}$-have been idle since 1988 for procedural upgrades and safety testing.

Atmospheric venting from the reactor buildings consists of air that has been pulled into the process building and is exhausted through a filtration system. This ventilation air does not directly exchange with the gases that are present inside the reactor tank itself and does not ventilate the area above the vertical tube storage (VTS) or disassembly basins where the fuel and target tubes are stored after use in the reactor.

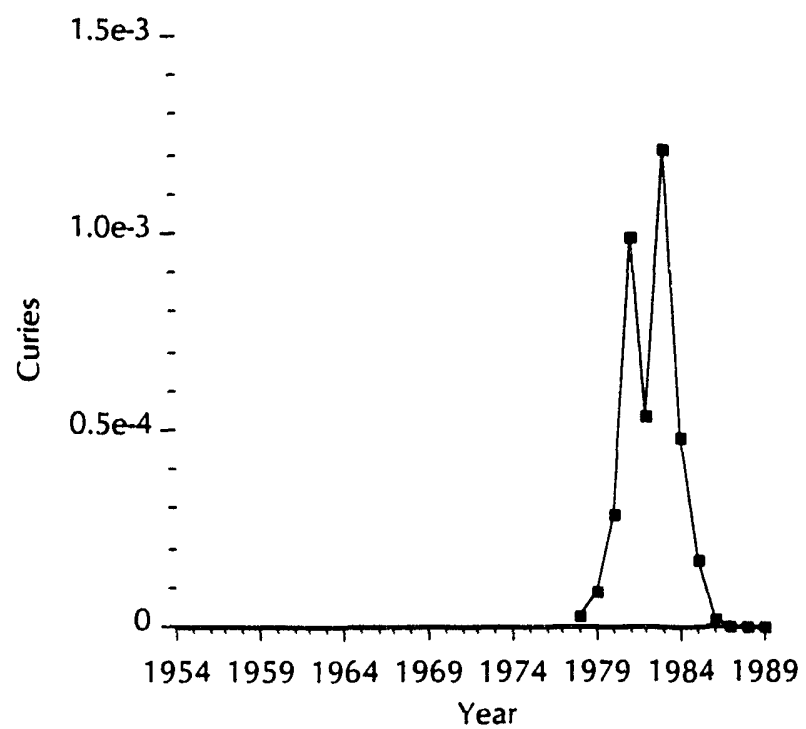

Figure 2-17. Gross Alpha Releases to Seepage Basins, C Area

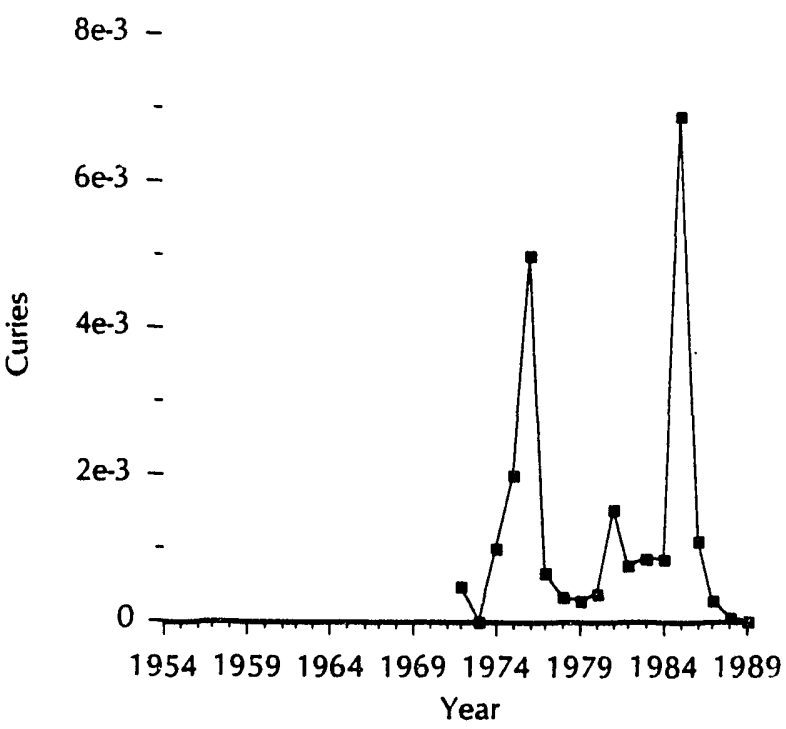

Figure 2-18. Gross Alpha Releases to Seepage Basins, K Area

The secondary cooling water for the reactors comes from the Savannah River and is returned to the river through streams on site. This water does not come directly in contact with the reactor core itself but is used to cool the heavy water that serves as moderator and primary coolant. This water is fed from pumping stations into holding basins at each reactor area and is then passed through heat exchangers and discharged to an effluent canal. Hot water from the effluent

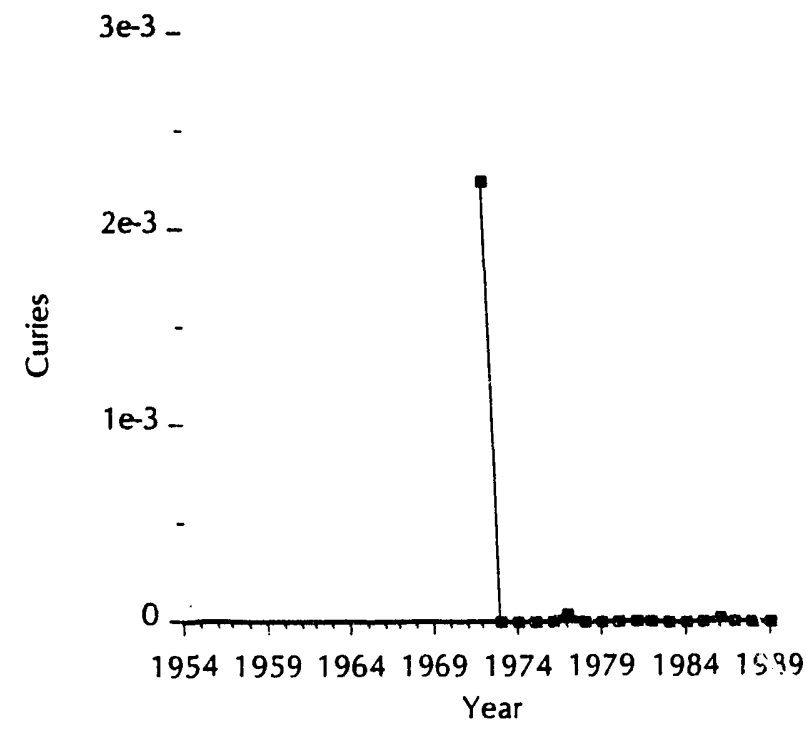

Figure 2-19. Gross Alpha Releases to Seepage Basins, L Area 


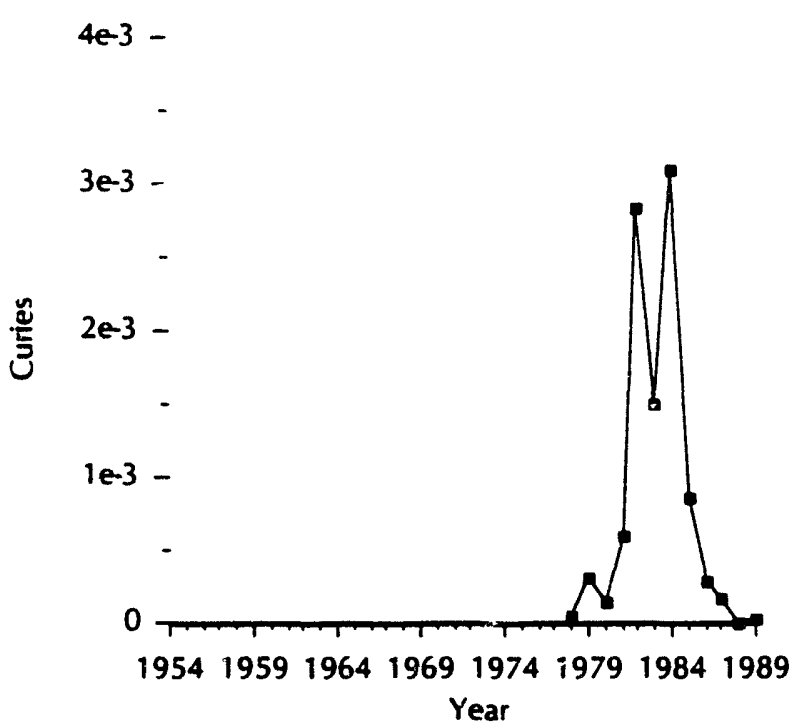

Figure 2-20. Gross Alpha Releases to Seepage Basins. P Area

canals is routed into an onsite stream or cooliny lakes before returning to the river.

P Area cooling water is recirculated through Par Pond, an on-site cooling lake. Overflow from Par Pond discharges to Lower Three Runs Creek and into the Savannah River. L-Area cooling water is discharged into L Lake, another on-site cooling lake. Overflow from L Lake goes into Steel Creek and into the Savannah River swamp. A cooling tower is being constructed in $\mathrm{K}$ Area to minimize the effects of the discharge of hot water into Pen Branch and the river.

Spent fuel and irradiated target elements were removed from the reactor and stored in large water-filled basins in a

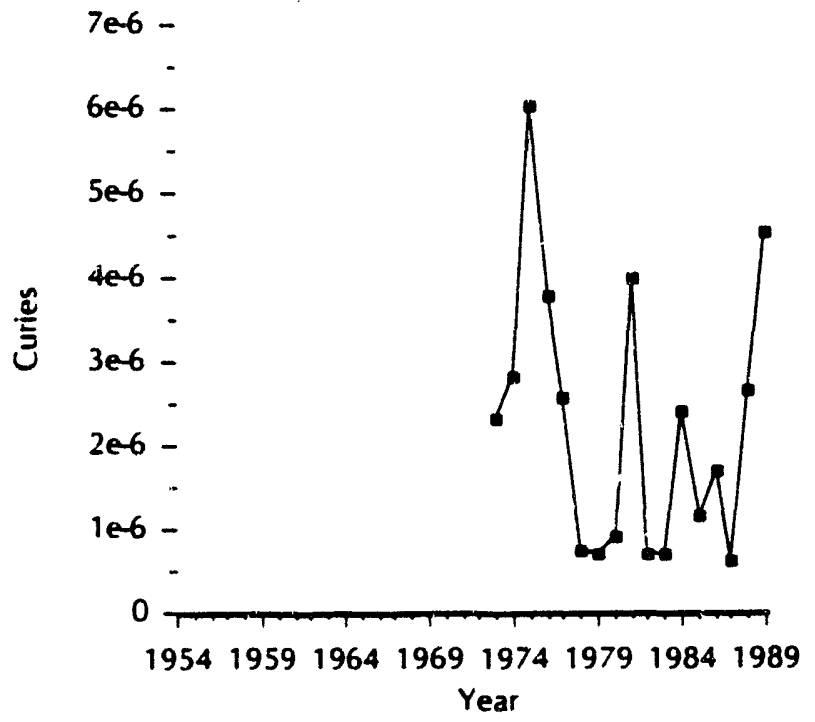

Figure 2-21. Gross Alpha Releases to Atmosphere, C Area

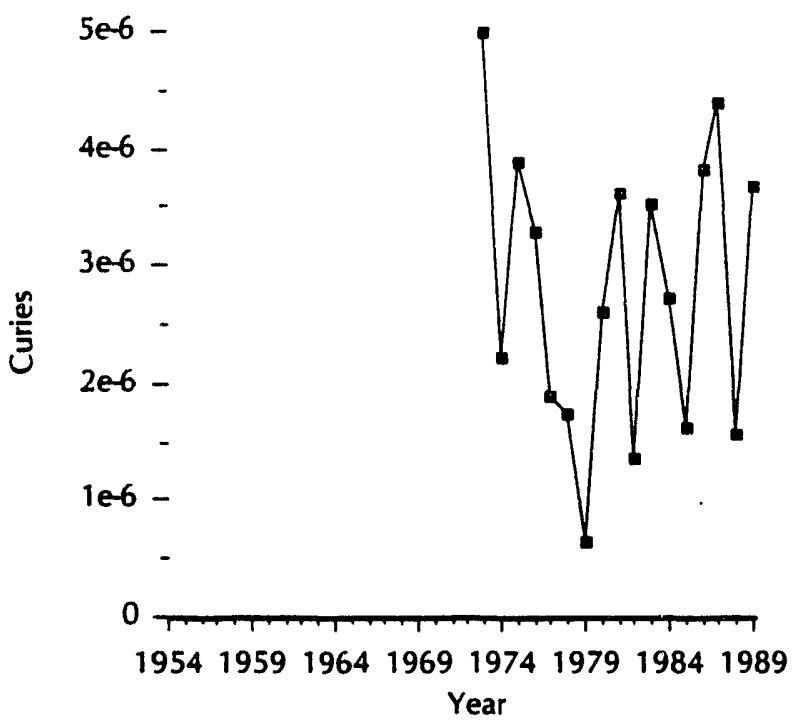

Figure 2-22. Gross Alpha Releases to Atmosphere, $K$ Area

facility adjacent to the reactor building. The water in these vertical tube storage (VTS) basins and disassembly basins serves as a coolant and as shielding for the intensely radioactive components. From startup to the mid-1960s, visual clarity was maintained in the basins by continuously purging them with fresh, filtered river water. The basin purge water was normally discharged to the plant streams along with the secondary cooling water. Occasionally, water from the VTS was purged to seepage basins to minimize the release of radioacivity to streams. This accounts for the sporadic use of the basins seen in Figures 2-17 to 2-20.

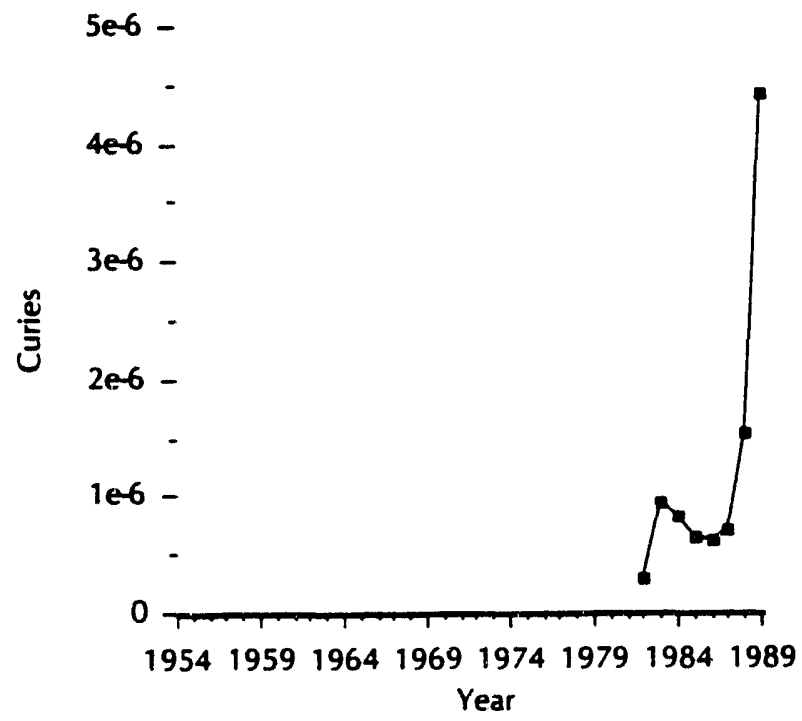

Figure 2-23. Gross Alpha Releases to Atmosphere. L Area 


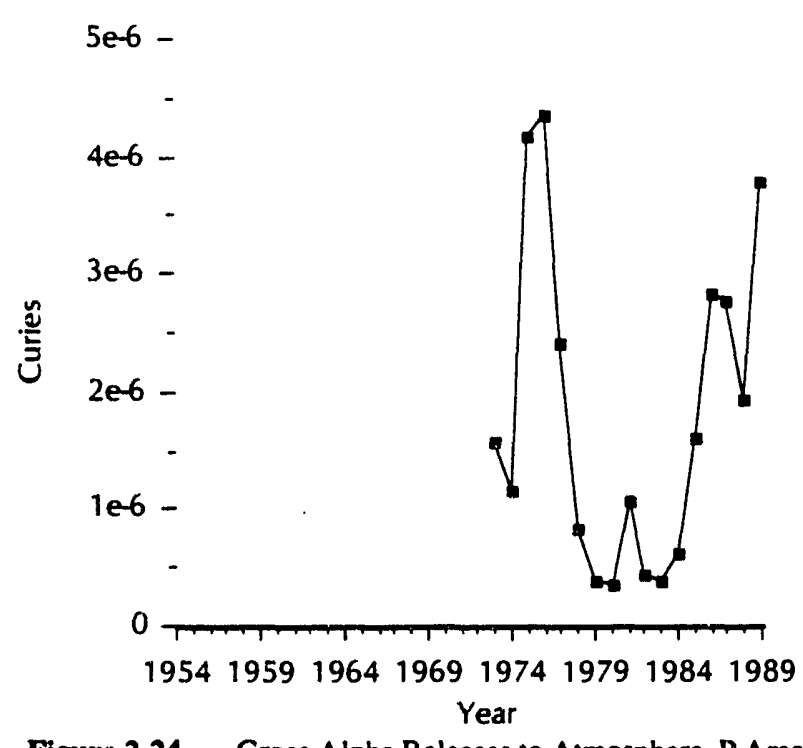

Figure 2-24. Gross Alpha Releases to Atmosphere, P Area

As part of a continuing effort to minimize radioactive discharges to the Savannah River, water was recirculated through filters on the VTS basins in the 1960 s to maintain water clarity. Sand filters were added to the disassembly basins in the early 1970s, and continuous basin purging to streams was discontinued. Because tritium is not removed by sand filters, periodic purges of the storage basins are necessary to reduce the tritium exposures to operating personnel. Portable ion exchange filters are used during the purges of the basins to minimize the release of all the radioactive species except tritium (the spent resins were recharged in the Receiving Basin for Offsite Fuel (RBOF) facility or sent to the burial ground). From 1970 to 1977 , water from these purges was discharged directly to the

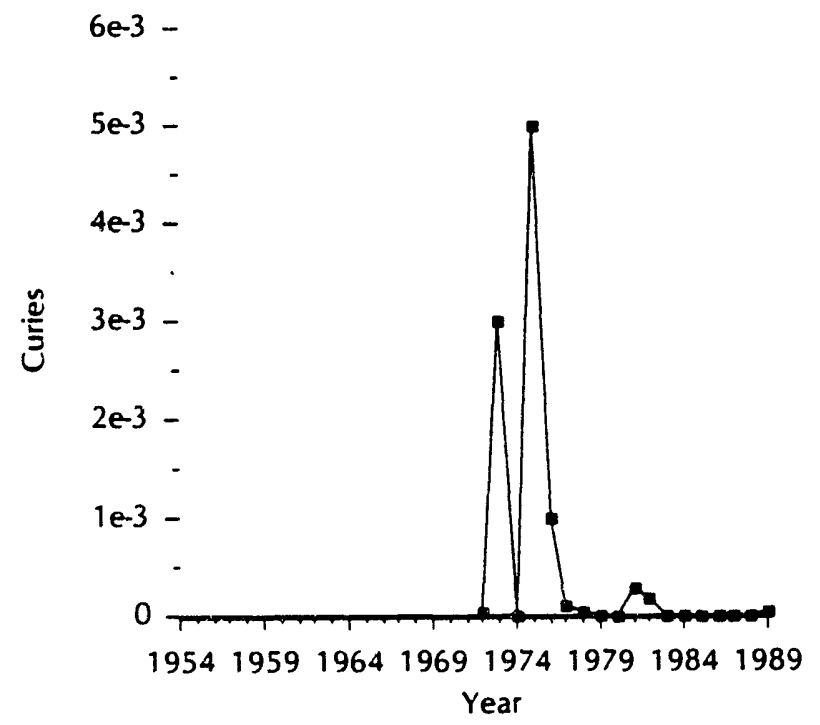

Figure 2-25. Gross Alpha Releases to Streams. C Area

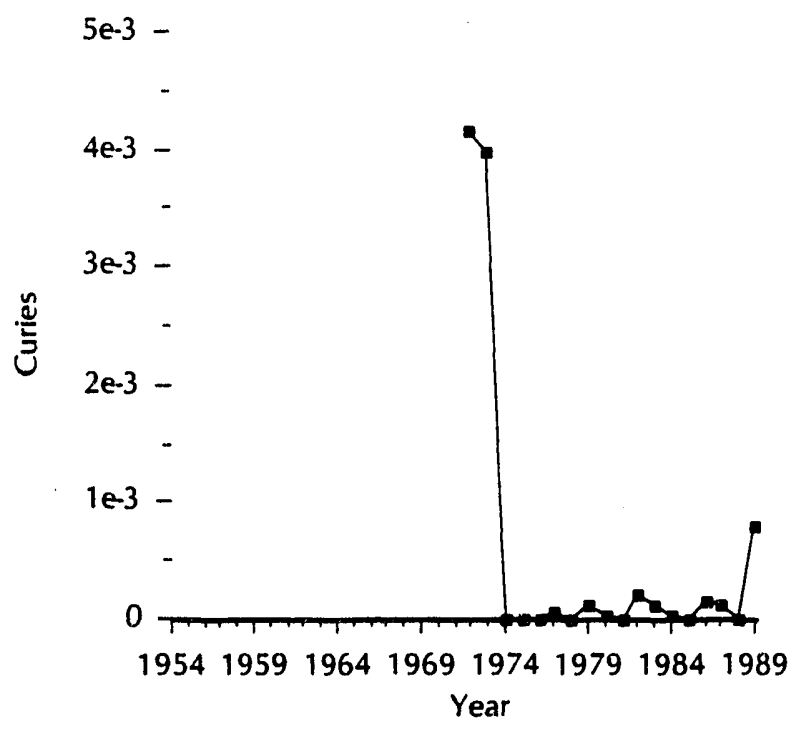

Figure 2-26. Gross Alpha Releases to Streams, K Area

effluent streams so there were no discharges to the seepage basins. Beginning in 1978, purge water from the fuel storage basins was redirected to the seepage basins to minimize direct tritium releases to the streams.

Releases of radioactivity to the Reactor Area seepage basins are not easily correlated to any history of operation as the reactors themselves were frequently idle during the periods shown in the graphs (Figures 2-17 to 2-20). With the very small releases for any given year, it is likely that the releases are the rsiult of unplanned events as opposed to regular releases.

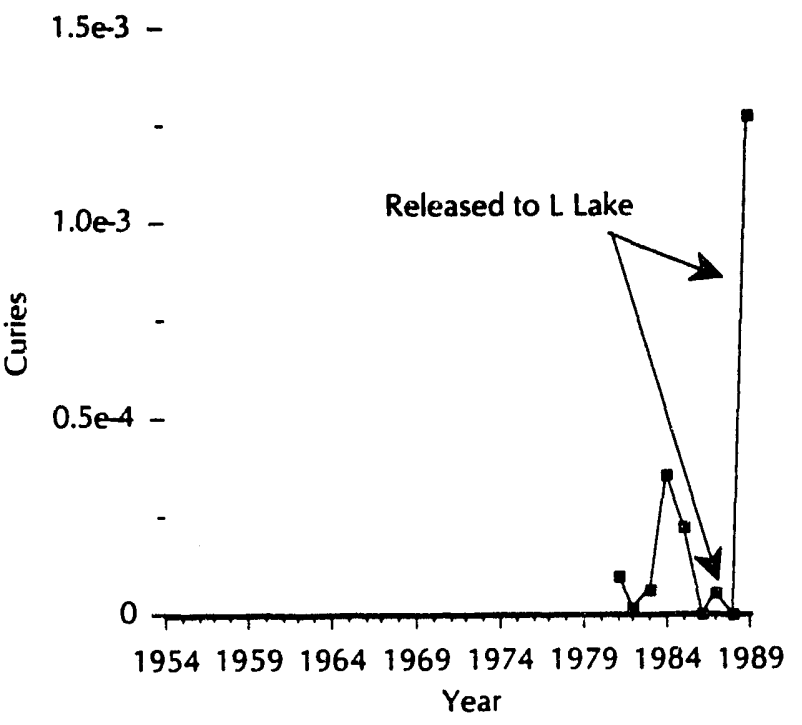

Figure 2-27. Gross Alpha Releases to Streams, L Area 


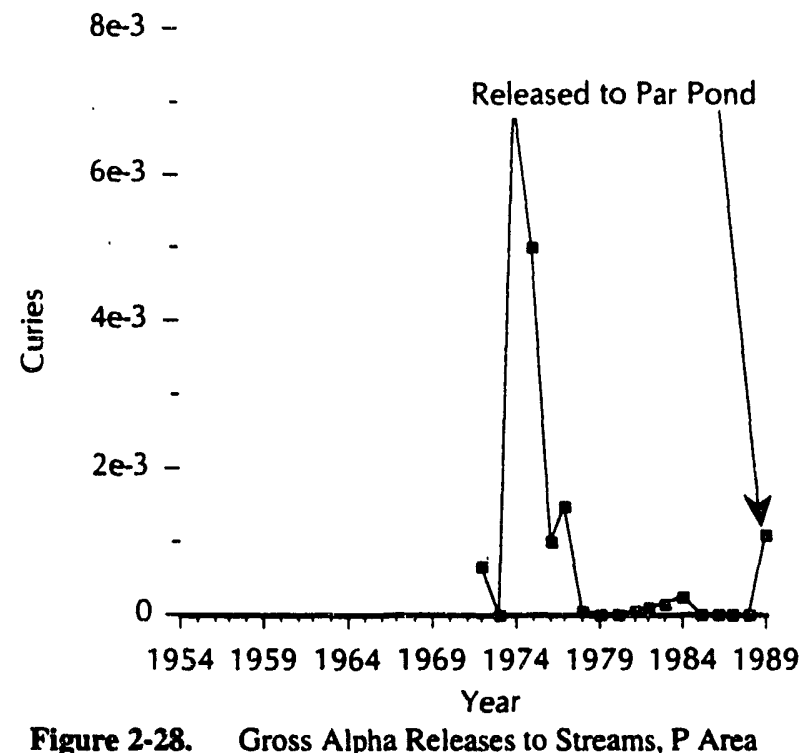

Figure 2-28. Gross Alpha Releases to Streams, P Area
It is also highly unlikely that these releases were solely the product of released uranium, which might occur in a rupture or leakage of a fuel or target element. If such a situation did occur, uranium would be released into the water of the VTS basin and would be oxidized to $\mathrm{U}_{3} \mathrm{O}_{8}$ in the form of a fine black powder. $\mathrm{U}_{3} \mathrm{O}_{8}$, uranium metal, and $\mathrm{UO}_{2}$ are virtually insoluble in neutral water. Therefore, any uranium released from a fuel or target rupture would be captured on the sand filters or would settle to the bottom of the VTS basin.

Uranium releases from $P, K, L$, and $C$ reactors are shown in Figures 2-17 through 2-28 (assuming all the unidentified alpha activity is uranium). The same data are presented in Table 2-3 (see page 2-23). It should be noted that the releases to streams are uncorrected for the natural uranium content of the incoming river water from which the purge water was derived, so a portion of these releases is not of SRS origin. 


\section{D-Area Releases To Streams}

D Area was used in the past for the separation of heavy water $\left(D_{2} O\right)$ from Savannah River water and for the removal of light water $\left(\mathrm{H}_{2} \mathrm{O}\right)$ from used moderator. After the reactor moderator inventory was established, separation of heavy water from river water was decreased and then discontinued. The deuterium separation process had insignificant potential for the release of alpha activity. The rework of degraded moderator from reactor areas is the most likely source of the majority of the activity. Though there are coal and coal ash storage pits in the area that, like the storage pits of commercial coal fired power plants, have potential uranium concentrations 252 times the EPA drinking water limits (Nakaoka, 1984), run-off from these pits has been minimized because of the application of federal regulations restricting such releases. The releases from $D$ Area to streams are shown in Figure 2-29 and Table 2-3 (see page $2-25$ ). There is no readily discernible pattern to the releases and the maximum possible uranium release to the environment from 1954 through 1989 is $9.158 \times 10^{-3}$ curies.

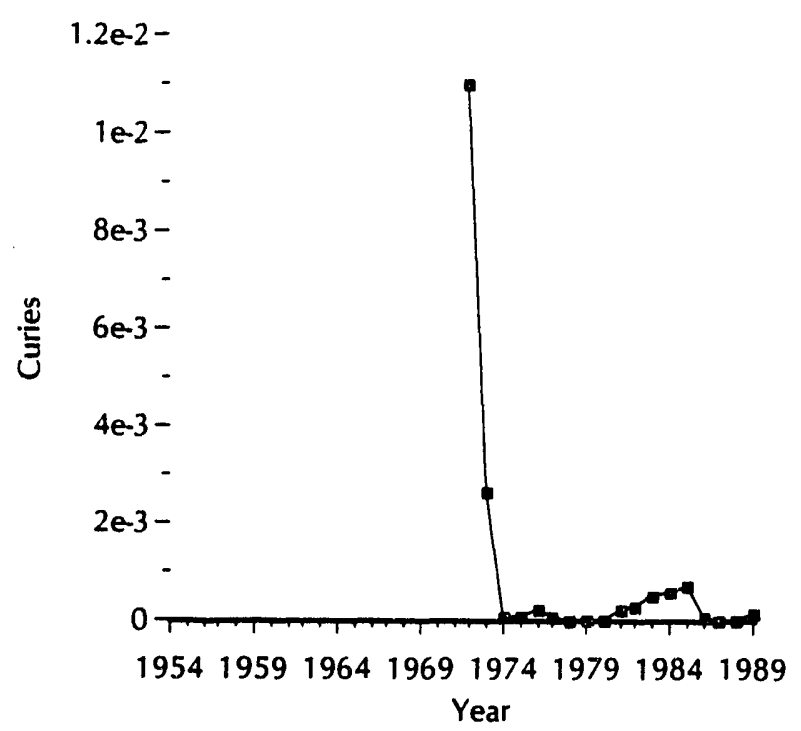

Figure 2-29. Gross Alpha Releases to Streams, D Area 


\section{Central Shops Releases To Seepage Basins}

Central Shops at SRS was responsible for fabrication and repair of equipment used in the separations and reactor areas of the site. Though equipment was decontaminated before it was sent to Central Shops, some radioactive material was occasionally present and was normally removed during cleaning operations prior to repair of the equipment. The contamination was transferred along with other liquid waste streams to a seepage basin. The yearly releases for alpha activity are shown in Figure 2-30 and Table 2-3 (see page 2-25). The maximum possible total uranium release for this location is $2.72 \times 10^{-4}$ curies of uranium.

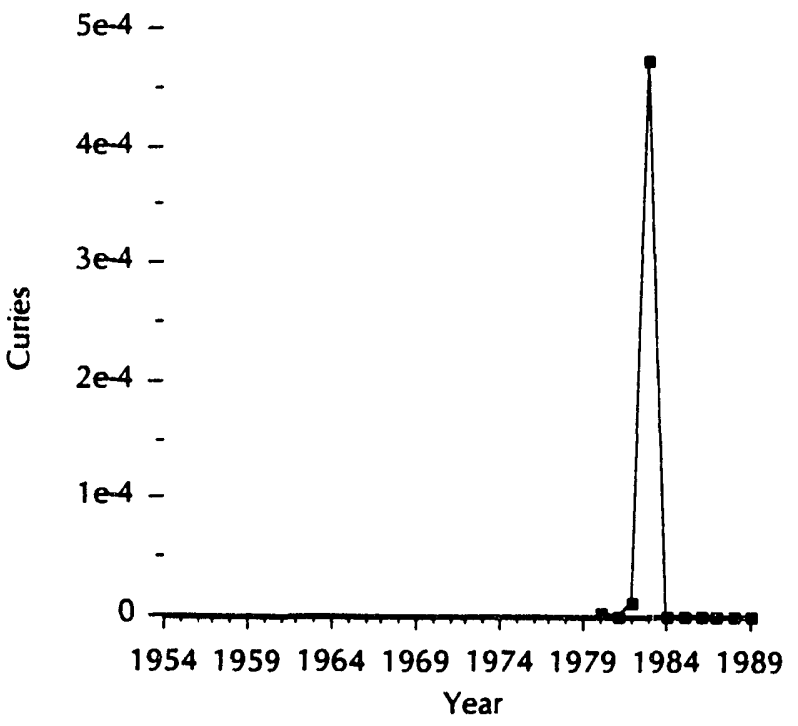

Figure 2.30. Gross Alpha Releases to Seepage Basins, Central Shops 


\section{Uranium In The Solid Waste Disposal Facility}

Residues of manufacture containing natural, depleted, and enriched uranium are buried onsite in a variety of forms in the Solid Waste Disposal Facility (SWDF) (formerly called the burial ground). On a mass basis, the bulk of these residues originated in the fuel fabrication facilities (M Area). Most of the natural and depleted uranium wastes are contained in 55-gallon steel drums. These wastes consist principally of aqueous sludges and filtered precipitates recovered from cleaning and plating solutions used during the preparation of uranium metal fuel and target elements.

The enriched uranium wastes, also contained in 55-gallon steel drums, are of two types, designated as M-Area wastes and F-Area wastes. Isotopic composition of the various forms of uranium are shown in Table 2.4.

The mean value of the specific activities, weighted according to quantities of each type of uranium waste in the SWDF is $0.7 \mathrm{mCi} / \mathrm{g}$, about equal to that of natural uranium.

The M-Area wastes were generated in the preparation of conventional enriched uranium fuel for the the SRS reactors. The M-Area wastes consist largely of job control items such as wipes, plastic, and general trash containing low levels of enriched uranium. The F-Area wastes derive from a special fuel preparation operation carried out during 1986-1990. F-Area wastes were generated in both solid and liquid form. Solid waste forms sent to the SWDF consisted of high-density wastes (pumps, pipes, and hardware) or low-density (job control) waste. Both types of waste were
Table 2-5. Inventory of Uranium Waste Disposed at SRS

$\begin{array}{lcr} & \begin{array}{c}\text { Metric } \\ \text { Tons }\end{array} & \text { Ci* }^{*} \\ \text { Depleted } & 187.9 & 63.9 \\ \text { Natural } & 9.5 & 6.6 \\ & & \\ \text { Enriched } & & \\ \text { Type M } & 0.6 & 53.4 \\ \text { Type F } & 0.15 & 16.5 \\ \text { Total } & 198.15 & 140.4\end{array}$

*See Table 2-4 for specific activity values

(Cook, McDonell \& Wilhite, 1990)

packaged along with low-density scrap in steel drums. Aqueous process wastes from the F-Area special fuel preparation operation were concentrated by evaporation, immobilized as a cement-based solid within drums, and placed in one cell of the Z-Area saltstone vault for disposal. Clean grout surrounds the drums.

The total inventory of uranium waste disposed of at SRS is shown in Table 2-5.

Table 2-4. Isotopic Composition and Specific Activities of Savannah River Uranium Wastes (Approximate)

\begin{tabular}{|c|c|c|c|c|c|}
\hline \multirow[b]{2}{*}{ Isotope } & \multicolumn{3}{|c|}{ Isotopic Composition wt \% } & \multirow[b]{2}{*}{238} & \multirow{2}{*}{$\begin{array}{l}\text { Specific } \\
\text { Activity } \\
\\
\mu \mathrm{Ci} / \mathrm{g}^{*}\end{array}$} \\
\hline & 234 & 235 & 236 & & \\
\hline Half Life (yrs) & $2.4 e+05$ & $7.0 e+08$ & $2.3 e+07$ & $4.5 e+09$ & \\
\hline Depleted & - & 0.2 & - & 99.8 & 0.34 \\
\hline Natural & 0.0055 & 0.7200 & - & 99.2745 & 0.69 \\
\hline \multicolumn{6}{|l|}{ Enriched } \\
\hline Type $\mathbf{M}$ & 1.2 & 65.8 & 19.6 & 13.1 & 89. \\
\hline Type F & 1.7 & 97.3 & - & 1.0 & 110 \\
\hline
\end{tabular}

*Rounded to two significant figures

(Cook, McDonell, \& Wilhite, 1990) 


\section{References}

Bebbington, W. P., 1990, The History of Du Pont at the Savannah River Plant, E. I. du Pont de Nemours \& Co., Wilmington, DE.

Cook, J. R., W. R. McDonnell, and E. L. Wilhite, 1990, Uranium Waste Disposal at the Savannah River Site $(U)$, WSRC-MS-90-209; Westinghouse Savannah River Company, Aiken, SC.

Cummings, C. L., C. S. Hetrick, D. K. Martin, 1991, Radioactive Releases at the Savannah River Site 1954-1989 $(U)$, WSRC-RP-91-684; Westinghouse Savannah River Company, Aiken, SC.

Cummins, C. L., D. K. Martin, and J. L. Todd, 1990 , Savannah River Site Environmental Report for 1989 (U), WSRC-IM-90-60 (2 Volumes), Westinghouse Savannah River Company, Aiken, SC.
Hyder, M. L., W. C. Perkins, M. C. Thompson, G. A. Burney, E. R. Russel, H. P. Holcomb, and L. F. Landon, 1979, Processing of Irradiated, Enriched Uranium Fuels at the Savannah River Plant, DP-1500, E. I du Pont de Nemours \& Co., Savannah River Plant, Aiken, SC.

Nakaoka, A., F. Masanori, and T. Shinji, 1984, Environmental Effects of Natural Radionuclides from Coal-Fired Power Plants, Health Physics, Vol 47, (3).

Pickett, J. B. and W. L. McDowell, 1990, Heavy Metal Contamination in Tims Branch Sediment, OPSRMT-900200, June 1990.

Starks, J.B., 1977, The Purex Process, DPSPU-77-11-1, E.I du Pont de Nemours \& Co., Savannah River Plant, Aiken, SC. 
Table 2-3. Yearly Uranium Releases from SRS Areas in Curies (page 1 of 5)

\begin{tabular}{|c|c|c|c|c|c|c|}
\hline & F Area* & F Area* & F Areat & H Areat & H Area* & H Area": \\
\hline Year & Atmos & Basins & Stream & Atmos & Basins & Stream \\
\hline Figure No. & $2-1$ & $2-2$ & $2-4$ & $2-5$ & $2-6$ & $2-7$ \\
\hline 1954 & 0.00 & 0.00 & $2.400 \mathrm{e}-03$ & 0.00 & 0.00 & 0.00 \\
\hline 1955 & $1.170 \mathrm{e}-01$ & $1.374 \mathrm{e}-01$ & $4.510 \mathrm{e}-02$ & $1.890 \mathrm{e}-01$ & $2.850 \mathrm{e}-02$ & $1.250 \mathrm{e}-03$ \\
\hline 1956 & $1.120 \mathrm{e}-01$ & $5.394 \mathrm{e}-01$ & $3.700 \mathrm{e}-02$ & $7.000 \mathrm{e}-03$ & $1.805 \mathrm{e}-01$ & $5.100 \mathrm{e}-03$ \\
\hline 1957 & $2.000 \mathrm{e}-03$ & $4.938 \mathrm{e}-01$ & $2.200 \mathrm{e}-03$ & $2.500 \mathrm{e}-04$ & $2.838 \mathrm{e}-01$ & $1.800 \mathrm{e}-03$ \\
\hline 1958 & $1.000 \mathrm{e}-03$ & $4.360 \mathrm{e}-01$ & $2.000 \mathrm{e}-03$ & $6.000 \mathrm{e}-04$ & $7.600 \mathrm{e}-02$ & $9.000 \mathrm{e}-03$ \\
\hline 1959 & $7.000 \mathrm{e}-03$ & $5.920 \mathrm{e}-01$ & $2.000 \mathrm{e}-03$ & $1.500 \mathrm{e}-04$ & $1.040 \mathrm{e}-01$ & $1.100 \mathrm{e}-02$ \\
\hline 1960 & $1.968 \mathrm{e}-02$ & $8.112 \mathrm{e}-01$ & $9.300 \mathrm{e}-03$ & $3.000 \mathrm{e}-04$ & $2.430 \mathrm{e}-(02$ & $7.500 \mathrm{e}-03$ \\
\hline 1961 & $9.000 e-03$ & $2.514 \mathrm{e}-01$ & $7.000 \mathrm{e}-03$ & $1.200 \mathrm{e}-03$ & $1.145 \mathrm{e}-01$ & $9.800 \mathrm{e}-03$ \\
\hline 1962 & $7.840 \mathrm{e}-03$ & $5.742 \mathrm{e}-01$ & $2.900 \mathrm{e}-03$ & $1.020 \mathrm{e}-03$ & $8.400 \mathrm{e}-02$ & $8.600 \mathrm{e}-03$ \\
\hline 1963 & $2.574 \mathrm{e}-02$ & $6.583 e-01$ & $5.000 \mathrm{e}-03$ & $5.760 \mathrm{e}-03$ & $4.702 \mathrm{e}-02$ & $1.100 \mathrm{e}-02$ \\
\hline 1964 & $4.218 \mathrm{e}-02$ & $1.176 \mathrm{e}+00$ & $3.000 \mathrm{e}-03$ & $1.336 \mathrm{e}-03$ & $1.094 \mathrm{e}-01$ & $1.200 \mathrm{e}-02$ \\
\hline 1965 & $5.110 \mathrm{e}-02$ & $5.882 \mathrm{e}-01$ & $2.000 \mathrm{e}-03$ & $7.000 \mathrm{e}-04$ & $7.230 \mathrm{e}-02$ & $9.000 \mathrm{e}-03$ \\
\hline 1966 & $1.945 \mathrm{e}-02$ & $4.902 \mathrm{e}-01$ & $4.100 \mathrm{e}-03$ & $1.145 \mathrm{e}-03$ & $2.240 \mathrm{e}-02$ & $1.000 \mathrm{e}-02$ \\
\hline 1967 & $1.828 \mathrm{e}-02$ & $1.763 \mathrm{e}-01$ & $1.030 \mathrm{e}-02$ & $8.750 \mathrm{e}-04$ & $1.443 e-02$ & $5.400 \mathrm{e}-02$ \\
\hline 1968 & $9.512 \mathrm{e}-02$ & $2.510 \mathrm{e}-01$ & $6.800 \mathrm{e}-03$ & $1.717 \mathrm{e}-02$ & $7.799 \mathrm{e}-02$ & $5.100 \mathrm{e}-03$ \\
\hline 1969 & $3.620 \mathrm{e}-02$ & $9.729 e-01$ & $4.500 \mathrm{e}-03$ & $3.247 \mathrm{e}-02$ & $2.707 e-02$ & $6.100 \mathrm{e}-03$ \\
\hline 1970 & $1.379 \mathrm{e}-02$ & $1.380 \mathrm{e}+00$ & $9.300 \mathrm{e}-03$ & $2.850 \mathrm{e}-03$ & $3.000 \mathrm{e}-02$ & $7.800 \mathrm{e}-03$ \\
\hline 1971 & $2.720 \mathrm{e}-03$ & $2.200 e-01$ & $1.180 \mathrm{e}-02$ & $2.450 \mathrm{e}-03$ & $2.000 \mathrm{e}-02$ & 0.00 \\
\hline 1972 & $5.190 \mathrm{e}-03$ & $2.300 \mathrm{e}-01$ & $5.460 \mathrm{e}-03$ & $2.540 \mathrm{e}-03$ & 0.00 & 0.00 \\
\hline 1973 & $3.580 \mathrm{e}-03$ & $1.578 \mathrm{e}-01$ & $8.780 \mathrm{e}-03$ & $1.530 \mathrm{e}-03$ & $1.590 \mathrm{e}-02$ & 0.00 \\
\hline 1974 & $8.610 \mathrm{e}-03$ & $9.780 \mathrm{e}-02$ & $5.430 \mathrm{e}-03$ & $6.000 \mathrm{e}-05$ & $5.300 \mathrm{e}-03$ & $1.920 \mathrm{e}-03$ \\
\hline 1975 & $4.694 \mathrm{e}-03$ & $1.151 \mathrm{e}-01$ & $4.540 \mathrm{e}-03$ & $3.000 \mathrm{e}-05$ & $7.000 \mathrm{e}-04$ & $1.770 \mathrm{e}-03$ \\
\hline 1976 & $4.870 e-03$ & $2.390 e-01$ & $2.350 \mathrm{e}-03$ & $1.000 \mathrm{e}-04$ & $1.200 \mathrm{e}-02$ & $2.750 \mathrm{e}-03$ \\
\hline 1977 & $1.231 \mathrm{e}-03$ & $9.900 \mathrm{e}-02$ & $2.790 \mathrm{e}-03$ & $3.200 \mathrm{e}-04$ & $3.000 \mathrm{e}-03$ & $3.200 \mathrm{e}-03$ \\
\hline 1978 & $2.538 \mathrm{e}-03$ & $1.140 \mathrm{e}-01$ & $2.501 \mathrm{e}-03$ & $5.210 \mathrm{e}-04$ & $8.000 \mathrm{e}-03$ & $2.706 \mathrm{e}-03$ \\
\hline 1979 & $2.050 e-03$ & $1.070 \mathrm{e}-01$ & $4.500 \mathrm{e}-03$ & $3.860 \mathrm{e}-04$ & $8.000 \mathrm{e}-03$ & $3.680 \mathrm{e}-03$ \\
\hline 1980 & $3.418 \mathrm{e}-03$ & $1.820 \mathrm{e}-01$ & $3.120 \mathrm{e}-03$ & $5.960 \mathrm{e}-04$ & $9.000 e-03$ & $2.480 \mathrm{e}-03$ \\
\hline 1981 & $4.303 e-03$ & $6.133 e-01$ & $5.790 \mathrm{e}-03$ & $1.768 e-03$ & $1.054 \mathrm{e}-02$ & $9.400 \mathrm{e}-04$ \\
\hline 1982 & $8.487 e-03$ & $1.467 e-01$ & $6.200 \mathrm{e}-03$ & $6.570 \mathrm{e}-04$ & $6.117 \mathrm{e}-03$ & $1.960 \mathrm{e}-03$ \\
\hline 1983 & $4.243 e-03$ & 6.82 le -02 & $4.450 \mathrm{e}-03$ & $2.180 \mathrm{e}-04$ & $3.760 \mathrm{e}-03$ & $1.370 \mathrm{e}-03$ \\
\hline 1984 & $1.794 e-03$ & $4.200 z-02$ & $2.914 \mathrm{e}-02$ & $3.950 \mathrm{e}-04$ & $3.000 \mathrm{e}-03$ & $7.310 \mathrm{e}-04$ \\
\hline 1985 & $2.126 \mathrm{e}-03$ & $1.150 \mathrm{e}-01$ & $5.137 \mathrm{e}-03$ & $3.990 \mathrm{e}-04$ & $3.000 \mathrm{e}-03$ & $7.700 \mathrm{e}-04$ \\
\hline 1986 & $1.244 \mathrm{e}-03$ & $1.15 e+00$ & $7.193 e-03$ & $2.270 \mathrm{e}-04$ & $2.090 \mathrm{e}-03$ & $9.350 \mathrm{e}-04$ \\
\hline 1987 & $8.382 \mathrm{e}-03$ & $3.800 \mathrm{e}-02$ & $3.338 \mathrm{e}-03$ & $1.160 \mathrm{e}-04$ & $1.435 \mathrm{e}-02$ & $1.447 e-02$ \\
\hline 1988 & $1.356 \mathrm{e}-03$ & $2.200 \mathrm{e}-02$ & $4.669 e-03$ & $1.090 \mathrm{e}-04$ & $1.565 \mathrm{e}-04$ & $6.490 \mathrm{e}-04$ \\
\hline 1989 & $4.901 \mathrm{e}-03$ & 0.00 & $8.386 \mathrm{e}-03$ & $1.480 \mathrm{e}-04$ & 0.00 & $1.957 \mathrm{e}-03$ \\
\hline
\end{tabular}

* Based on specific radiochemical analyses for uranium

+ Based on gross alpha analyses 
Table 2-3. Yearly Uranium Releases from the SRS Areas in Curies (page 2 of 5)

\begin{tabular}{|c|c|c|c|c|c|c|}
\hline & SRL-At & SRL-At & SRL-At & M Area": & M Area* & M Area* \\
\hline Year & Atmos & Basins & Stream & Atmos & Basins & Stream \\
\hline Figure No. & $2-12$ & $2-13$ & $2-15$ & $2-9$ & $2-11$ & $2-10$ \\
\hline 1954 & N.A. & $2.800 \mathrm{e}-04$ & N.A. & N.A. & N.A. & N.A. \\
\hline 1955 & N.A. & $2.470 t-02$ & N.A. & N.A. & N.A. & $8.780 \mathrm{e}-02$ \\
\hline 1956 & N.A. & $7.871 \mathrm{e}-02$ & N.A. & N.A. & N.A. & $6.521 \mathrm{e}-01$ \\
\hline 1957 & N.A. & $3.562 \mathrm{e}-02$ & N.A. & N.A. & N.A. & $1.317 \mathrm{e}-01$ \\
\hline 1958 & N.A. & $4.358 \mathrm{e}-02$ & N.A. & N.A. & N.A. & $4.510 \mathrm{e}-02$ \\
\hline 1959 & N.A. & $1.912 \mathrm{e}-02$ & N.A. & N.A. & N.A. & $4.890 \mathrm{e}-02$ \\
\hline 1960 & N.A. & $3.000 \mathrm{e}-02$ & N.A. & N.A. & N.A. & $1.379 \mathrm{e}-01$ \\
\hline 1961 & $2.200 \mathrm{e}-04$ & $2.900 \mathrm{e}-02$ & N.A. & N.A. & N.A. & $1.379 \mathrm{e}-01$ \\
\hline 1962 & $3.000 \mathrm{e}-04$ & $4.000 \mathrm{e}-02$ & N.A. & N.A. & N.A. & $6.649 e-01$ \\
\hline 1963 & $2.420 \mathrm{e}-04$ & $2.870 \mathrm{e}-02$ & N.A. & N.A. & N.A. & $2.449 e+00$ \\
\hline 1964 & 0.00 & $3.210 \mathrm{e}-02$ & N.A. & N.A. & N.A. & $6.220 \mathrm{e}-01$ \\
\hline 1965 & 0.00 & $3.900 \mathrm{e}-02$ & N.A. & N.A. & N.A. & $1.129 \mathrm{e}+00$ \\
\hline 1966 & 0.00 & $1.700 e-02$ & N.A. & N.A. & N.A. & $5.555 \mathrm{e}+00$ \\
\hline 1967 & 0.00 & $2.940 \mathrm{e}-02$ & N.A. & N.A. & N.A. & $8.054 \mathrm{e}+00$ \\
\hline 1968 & $5.000 \mathrm{e}-04$ & $2.587 \mathrm{e}-01$ & N.A. & N.A. & N.A. & $5.284 \mathrm{e}+00$ \\
\hline 1969 & $4.600 e-04$ & $9.440 e-01$ & N.A. & N.A. & N.A. & $1.583 e+00$ \\
\hline 1970 & $3.000 \mathrm{e}-04$ & $1.136 \mathrm{e}+100$ & $3.500 \mathrm{e}-03$ & N.A. & N.A. & $8.552 e-01$ \\
\hline 1971 & $5.000 \mathrm{e}-04$ & $9.794 \mathrm{e}-01$ & 0.00 & N.A. & N.A. & $4.364 e-01$ \\
\hline 1972 & 0.00 & $7.180 \mathrm{e}-02$ & 0.00 & N.A. & N.A. & $4.891 \mathrm{e}-01$ \\
\hline 1973 & $1.900 \mathrm{e}-05$ & $3.014 \mathrm{e}-01$ & 0.00 & N.A. & N.A. & $2.746 \mathrm{e}-01$ \\
\hline 1974 & $3.100 \mathrm{e}-05$ & $2.210 \mathrm{e}-02$ & $1.260 \mathrm{e}-03$ & N.A. & $2.220 \mathrm{e}-03$ & $4.376 \mathrm{e}-01$ \\
\hline 1975 & $3.000 \mathrm{e}-06$ & $2.677 e-03$ & $2.204 \mathrm{e}-03$ & $3.359 e-06$ & $1.886 \mathrm{e}-02$ & $5.530 \mathrm{e}-01$ \\
\hline 1976 & $2.000 \mathrm{e}-06$ & $5.060 \mathrm{e}-04$ & $1.014 \mathrm{e}-03$ & $2.449 \mathrm{e}-06$ & $8.850 \mathrm{e}-03$ & $4.552 \mathrm{e}-01$ \\
\hline 1977 & $1.000 \mathrm{e}-06$ & $3.299 e-05$ & $6.310 \mathrm{e}-04$ & $1.832 \mathrm{e}-05$ & $1.433 e-02$ & $1.058 \mathrm{e}-01$ \\
\hline 1978 & $3.000 \mathrm{e}-06$ & 0.00 & $4.410 \mathrm{e}-04$ & $2.271 \mathrm{e}-06$ & $5.833 \mathrm{e}-02$ & $7.010 e-02$ \\
\hline 1979 & 0.00 & 0.00 & $5.000 \mathrm{e}-04$ & $2.246 \mathrm{e}-06$ & $6.045 \mathrm{e}-02$ & $8.030 \mathrm{e}-02$ \\
\hline 1980 & $1.100 \mathrm{e}-05$ & $6.170 \mathrm{e}-04$ & $1.440 \mathrm{e}-04$ & $8.800 \mathrm{e}-08$ & $9.698 \mathrm{e}-02$ & $2.380 \mathrm{e}-01$ \\
\hline 1981 & 0.00 & 0.00 & $2.860 \mathrm{e}-04$ & 0.00 & $9.981 \mathrm{e}-02$ & $2.144 \mathrm{e}-01$ \\
\hline 1982 & 0.00 & $8.370 e-04$ & $2.370 \mathrm{e}-04$ & $2.923 e-06$ & $2.052 \mathrm{e}-01$ & $5.280 \mathrm{e}-02$ \\
\hline 1983 & $6.000 \mathrm{e}-06$ & 0.00 & $7.000 \mathrm{e}-05$ & $4.526 \mathrm{e}-06$ & $4.090 \mathrm{e}-01$ & $2.170 \mathrm{e}-02$ \\
\hline 1984 & 0.00 & 0.00 & $1.000 \mathrm{e}-04$ & 0.00 & $1.267 e-0.1$ & $1.220 \mathrm{e}-02$ \\
\hline 1985 & 0.00 & 0.00 & $1.300 \mathrm{e}-04$ & $1.140 \mathrm{e}-05$ & $5.053 e-02$ & $1.700 \mathrm{e}-03$ \\
\hline 1986 & $3.000 \mathrm{e}-06$ & 0.00 & $1.570 \mathrm{e}-04$ & $9.780 e-05$ & 0.00 & $5.500 \mathrm{e}-02$ \\
\hline 1987 & $1.200 \mathrm{e}-05$ & 0.00 & $2.600 \mathrm{e}-04$ & $2.219 \mathrm{e}-05$ & 0.00 & $6.900 \mathrm{e}-03$ \\
\hline 1988 & $1.000 e-05$ & 0.00 & $2.060 \mathrm{e}-04$ & $2.791 \mathrm{e}-06$ & 0.00 & $6.900 e-03$ \\
\hline 1989 & $1.000 \mathrm{e}-06$ & 0.00 & $2.710 e-04$ & $8.430 e-07$ & 0.00 & $5.000 \mathrm{e}-04$ \\
\hline
\end{tabular}

* Based on specific radiochemical analyses for uranium

$+\quad$ Based on gross alpha analyses

N.A. Not analyzed

$\checkmark \quad$ Revised releases, see Chapter 3 
Table 2-3. Yearly Uranium Releases from SRS Areas in Curies (page 3 of 5)

\begin{tabular}{|c|c|c|c|c|c|c|}
\hline Year & $\begin{array}{l}\text { C Areat } \\
\text { Atmos }\end{array}$ & $\begin{array}{l}\text { C Areat } \\
\text { Basins }\end{array}$ & $\begin{array}{l}\text { C Areat } \\
\text { Stream }\end{array}$ & $\begin{array}{l}\text { K Areat } \\
\text { Armos }\end{array}$ & $\begin{array}{l}\text { K Areat } \\
\text { Basins }\end{array}$ & $\begin{array}{l}\text { K Areat } \\
\text { Stream }\end{array}$ \\
\hline Figure No. & $2-21$ & $2-17$ & $2-25$ & $\overline{2-22}$ & $2-18$ & $2-26$ \\
\hline 1954 & N.A. & N.A. & N.A. & N.A. & N.A. & N.A. \\
\hline 1955 & N.A. & N.A. & N.A. & N.A. & N.A. & N.A. \\
\hline 1956 & N.A. & N.A. & N.A. & N.A. & N.A. & N.A. \\
\hline 1957 & N.A. & N.A. & N.A. & N.A. & N.A. & N.A. \\
\hline 1958 & N.A. & N.A. & N.A. & N.A. & N.A. & N.A. \\
\hline 1959 & N.A. & N.A. & N.A. & N.A. & N.A. & N.A. \\
\hline 1960 & N.A. & N.A. & N.A. & N.A. & N.A. & N.A. \\
\hline 1961 & N.A. & N.A. & N.A. & N.A. & N.A. & N.A. \\
\hline 1962. & N.A. & N.A. & N.A. & N.A. & N.A. & N.A. \\
\hline 1963 & N.A. & N.A. & N.A. & N.A. & N.A. & N.A. \\
\hline 1964 & N.A. & N.A. & N.A. & N.A. & N.A. & N.A. \\
\hline 1965 & N.A. & N.A. & N.A. & N.A. & N.A. & N.A. \\
\hline 1966 & N.A. & N.A. & N.A. & N.A. & N.A. & N.A. \\
\hline 1967 & N.A. & N.A. & N.A. & N.A. & N.A. & N.A. \\
\hline 1968 & N.A. & N.A. & N.A. & N.A. & N.A. & N.A. \\
\hline 1969 & N.A. & N.A. & N.A. & N.A. & N.A. & N.A. \\
\hline 1970 & N.A. & N.A. & N.A. & N.A. & N.A. & N.A. \\
\hline 1971 & N.A. & N.A. & N.A. & N.A. & N.A. & N.A. \\
\hline 1972 & N.A. & N.A. & $4.000 \mathrm{e}-05$ & N.A. & $4.700 \mathrm{e}-04$ & $4.160 \mathrm{e}-03$ \\
\hline 1973 & $2.340 \mathrm{e}-06$ & N.A. & $3.000 \mathrm{e}-03$ & $4.990 \mathrm{e}-06$ & 0.00 & $4.000 \mathrm{e}-03$ \\
\hline 1974 & $2.830 \mathrm{e}-06$ & N.A. & 0.00 & $2.220 \mathrm{e}-06$ & $1.000 \mathrm{e}-03$ & 0.00 \\
\hline 1975 & $6.060 e-06$ & N.A. & $5.000 \mathrm{e}-03$ & $3.900 \mathrm{e}-06$ & $2.000 \mathrm{e}-03$ & 0.00 \\
\hline 1976 & $3.810 \mathrm{e}-06$ & N.A. & $1.000 \mathrm{e}-03$ & $3.290 \mathrm{e}-06$ & $5.000 \mathrm{e}-03$ & 0.00 \\
\hline 1977 & $2.580 \mathrm{e}-06$ & NA. & $1.150 \mathrm{e}-04$ & $1.910 \mathrm{e}-06$ & $6.820 \mathrm{e}-04$ & $5.600 \mathrm{e}-05$ \\
\hline 1978 & $7.300 \mathrm{e}-07$ & $2.820 \mathrm{e}-05$ & $2.449 \mathrm{e}-05$ & $1.770 \mathrm{e}-06$ & $3.502 \mathrm{e}-04$ & 0.00 \\
\hline 1979 & $7.000 \mathrm{e}-07$ & $8.900 \mathrm{e}-05$ & $2.000 \mathrm{e}-06$ & $6.400 \mathrm{e}-07$ & $2.820 \mathrm{e}-04$ & $1.180 \mathrm{e}-04$ \\
\hline 1980 & $9.300 \mathrm{e}-07$ & $2.840 \mathrm{e}-04$ & 0.00 & $2.630 \mathrm{e}-06$ & $3.700 \mathrm{e}-04$ & $2.400 \mathrm{e}-05$ \\
\hline 1981 & $3.998 \mathrm{e}-06$ & $9.900 \mathrm{e}-04$ & $2.680 \mathrm{e}-04$ & $3.620 \mathrm{e}-06$ & $1.515 \mathrm{e}-03$ & 0.00 \\
\hline 1982 & $7.000 \mathrm{e}-07$ & $5.360 \mathrm{e}-04$ & $1.940 \mathrm{e}-04$ & $1.370 \mathrm{e}-06$ & $7.466 \mathrm{e}-04$ & $2.200 \mathrm{e}-04$ \\
\hline 1983 & $7.200 \mathrm{e}-07$ & $1.213 \mathrm{e}-03$ & 0.00 & $3.540 \mathrm{e}-06$ & $8.362 \mathrm{e}-04$ & $1.320 \mathrm{e}-04$ \\
\hline 1984 & $2.42 \mathrm{le}-06$ & $4.780 \mathrm{e}-04$ & 0.00 & $2.740 \mathrm{e}-06$ & $8.370 \mathrm{e}-04$ & $1.700 \mathrm{e}-05$ \\
\hline 1985 & $1.160 \mathrm{e}-06$ & $1.720 \mathrm{e}-04$ & 0.00 & $1.642 \mathrm{e}-06$ & $6.886 e-03$ & 0.00 \\
\hline 1986 & $1.700 \mathrm{e}-06$ & $1.754 \mathrm{e}-05$ & 0.00 & $3.830 \mathrm{e}-06$ & $1.085 \mathrm{e}-03$ & $1.340 \mathrm{e}-04$ \\
\hline 1987 & $6.400 \mathrm{e}-07$ & 0.00 & $1.200 \mathrm{e}-05$ & $4.405 \mathrm{e}-06$ & $2.64 \mathrm{le}-04$ & $1.310 \mathrm{e}-04$ \\
\hline 1988 & $2.684 \mathrm{e}-06$ & 0.00 & $1.200 \mathrm{e}-05$ & $1.580 \mathrm{e}-06$ & $6.415 \mathrm{e}-05$ & 0.00 \\
\hline 1989 & $4.541 \mathrm{e}-06$ & 0.00 & $4.300 \mathrm{e}-05$ & $3.697 e-06$ & $6.277 \mathrm{e}-06$ & $7.990 \mathrm{e}-04$ \\
\hline
\end{tabular}

$+\quad$ Based on gross alpha analyses

N.A. Not analyzed 
Table 2-3. Yearly Uranium Releases from SRS Areas in Curies (page 4 of 5)

\begin{tabular}{|c|c|c|c|c|c|c|}
\hline Year & $\begin{array}{l}\text { L Areat } \\
\text { Atmos }\end{array}$ & $\begin{array}{l}\text { L Areat } \\
\text { Basins }\end{array}$ & $\begin{array}{l}\text { L Areat } \\
\text { Stream }\end{array}$ & $\begin{array}{l}\text { P Areat } \\
\text { Atmos }\end{array}$ & $\begin{array}{l}\text { P Areat } \\
\text { Basins }\end{array}$ & $\begin{array}{l}\text { P Areat } \\
\text { Stream }\end{array}$ \\
\hline Figure No. & $2-23$ & $2-19$ & $2-27$ & $2-24$ & $2-20$ & $\overline{2-28}$ \\
\hline 1954 & N.A. & N.A. & N.A. & N.A. & N.A. & N.A. \\
\hline 1955 & N.A. & N.A. & N.A. & N.A. & N.A. & N.A. \\
\hline 1956 & N.A. & N.A. & N.A. & N.A. & N.A. & N.A. \\
\hline 1957 & N.A. & N.A. & N.A. & N.A. & N.A. & N.A. \\
\hline 1958 & N.A. & N.A. & N.A. & N.A. & N.A. & N.A. \\
\hline 1959 & N.A. & N.A. & N.A. & N.A. & N.A. & N.A. \\
\hline 1960 & N.A. & N.A. & N.A. & N.A. & N.A. & N.A. \\
\hline 1961 & N.A. & N.A. & N.A. & N.A. & N.A. & N.A. \\
\hline 1962 & N.A. & N.A. & N.A. & N.A. & N.A. & N.A. \\
\hline 1963 & N.A. & N.A. & N.A. & N.A. & N.A. & N.A. \\
\hline 1964 & N.A. & N.A. & N.A. & N.A. & N.A. & N.A. \\
\hline 1965 & N.A. & N.A. & N.A. & N.A. & N.A. & N.A. \\
\hline 1966 & N.A. & N.A. & N.A. & N.A. & N.A. & N.A. \\
\hline 1967 & N.A. & N.A. & N.A. & N.A. & N.A. & N.A. \\
\hline 1968 & N.A. & N.A. & N.A. & N.A. & N.A. & N.A. \\
\hline 1969 & N.A. & N.A. & N.A. & N.A. & N.A. & N.A. \\
\hline 1970 & N.A. & N.A. & N.A. & N.A. & N.A. & N.A. \\
\hline 1971 & N.A. & N.A. & N.A. & N.A. & N.A. & N.A. \\
\hline 1972 & N.A. & $2.250 \mathrm{e}-03$ & N.A. & N.A. & N.A. & $6.600 \mathrm{e}-04$ \\
\hline 1973 & N.A. & 0.00 & N.A. & $1.588 \mathrm{e}-06$ & N.A. & 0.00 \\
\hline 1974 & N.A. & 0.00 & N.A. & $1.160 \mathrm{e}-06$ & N.A. & $7.000 \mathrm{e}-03$ \\
\hline 1975 & N.A. & 0.00 & N.A. & $4.180 \mathrm{e}-06$ & N.A. & $5.000 \mathrm{e}-03$ \\
\hline 1976 & N.A. & 0.00 & N.A. & $4.360 \mathrm{e}-06$ & N.A. & $1.000 \mathrm{e}-03$ \\
\hline 1977 & N.A. & $3.200 \mathrm{e}-05$ & N.A. & $2.400 \mathrm{e}-06$ & N.A. & $1.469 \mathrm{e}-03$ \\
\hline 1978 & N.A. & $3.179 \mathrm{e}-06$ & N.A. & $8.300 \mathrm{e}-07$ & $3.965 \mathrm{e}-05$ & $5.054 \mathrm{e}-05$ \\
\hline 1979 & N.A. & 0.00 & N.A. & $4.000 \mathrm{e}-07$ & $3.170 \mathrm{e}-04$ & 0.00 \\
\hline 1980 & N.A. & 0.00 & N.A. & $3.500 \mathrm{e}-07$ & $1.460 \mathrm{e}-04$ & 0.00 \\
\hline 1981 & N.A. & 0.00 & $9.500 e-05$ & $1.070 e-06$ & $6.070 \mathrm{e}-04$ & $7.000 \mathrm{e}-05$ \\
\hline 1982 & $3.000 \mathrm{e}-07$ & 0.00 & $2.100 \mathrm{e}-05$ & $4.500 \mathrm{e}-07$ & $2.832 \mathrm{e}-03$ & $9.500 \mathrm{e}-05$ \\
\hline 1983 & $9.600 \mathrm{e}-07$ & 0.00 & $5.900 \mathrm{e}-05$ & $4.000 \mathrm{e}-07$ & $1.495 \mathrm{e}-03$ & $1.360 \mathrm{e}-04$ \\
\hline 1984 & $8.300 e-07$ & 0.00 & $3.580 e-04$ & $6.300 \mathrm{e}-07$ & $3.098 \mathrm{e}-03$ & $2.220 \mathrm{e}-04$ \\
\hline 1985 & $6.400 \mathrm{e}-07$ & 0.00 & $2.230 \mathrm{e}-04$ & $1.602 e-06$ & $8.610 e-04$ & 0.00 \\
\hline 1986 & $6.220 \mathrm{e}-07$ & $1.166 \mathrm{e}-05$ & 0.00 & $2.840 \mathrm{e}-06$ & $2.976 \mathrm{e}-04$ & 0.00 \\
\hline 1987 & $7.140 \mathrm{e}-07$ & $8.651 e-06$ & $4.10 \mathrm{e}-05^{*}$ & $2.770 \mathrm{e}-06$ & $1.753 \mathrm{e}-04$ & 0.00 \\
\hline 1988 & 1.54 le-06 & $7.598 \mathrm{e}-06$ & 0.00 & $1.940 \mathrm{e}-06$ & $3.065 e-06$ & 0.00 \\
\hline 1989 & $4.427 e-06$ & $1.162 e-07$ & $1.26 \mathrm{e}-03 *$ & $3.785 \mathrm{e}-06$ & $3.500 e-05$ & $1.11 e-03^{*}$ \\
\hline $\operatorname{Re}$ & \multicolumn{6}{|c|}{ Releases to Lakes } \\
\hline $\mathrm{Ba}$ & \multicolumn{6}{|c|}{ Based on gross alpha analyses } \\
\hline N.A. & \multicolumn{6}{|c|}{ Not analyzed } \\
\hline
\end{tabular}


Table 2-3. Uranium Releases from SRS Areas in Curies (page 5 of 5)

\begin{tabular}{|c|c|c|c|c|c|}
\hline & $\begin{array}{l}\text { SRL* } \\
\text { Bacin }\end{array}$ & D Areat & $\begin{array}{l}\text { C Shopst } \\
\text { Basin }\end{array}$ & $\begin{array}{l}\text { CMX* } \\
\text { Basin }\end{array}$ & $\begin{array}{l}\text { ETFt } \\
\text { Stream }\end{array}$ \\
\hline$\frac{\text { Year }}{\text { Figure No. }}$ & $\frac{\text { Basin }}{2-14}$ & $\frac{\text { Stream }}{2-29}$ & $\frac{\text { Basin }}{2-30}$ & $\frac{\text { Basin }}{2-16}$ & $\frac{\text { Stream }}{\text { N.A. }}$ \\
\hline 1954 & N.A. & N.A. & N.A. & N.A. & - \\
\hline 1955 & N.A. & N.A. & N.A. & N.A. & - \\
\hline 1956 & N.A. & N.A. & N.A. & N.A. & - \\
\hline 1957 & N.A. & N.A. & N.A. & N.A. & - \\
\hline 1958 & N.A. & N.A. & N.A. & N.A. & - \\
\hline 1959 & N.A. & N.A. & N.A. & N.A. & - \\
\hline 1960 & N.A. & N.A. & N.A. & N.A. & - \\
\hline 1961 & N.A. & N.A. & N.A. & N.A. & - \\
\hline 1962 & N.A. & N.A. & N.A. & N.A. & - \\
\hline 1963 & N.A. & N.A. & N.A. & N.A. & - \\
\hline 1964 & N.A. & N.A. & N.A. & N.A. & - \\
\hline 1965 & N.A. & N.A. & N.A. & N.A. & - \\
\hline 1966 & N.A. & N.A. & N.A. & N.A. & - \\
\hline 1967 & N.A. & N.A. & N.A. & N.A. & - \\
\hline 1968 & N.A. & N.A. & N.A. & $2.314 \mathrm{e}-01$ & - \\
\hline 1969 & N.A. & N.A. & N.A. & $1.074 \mathrm{e}-01$ & - \\
\hline 1970 & N.A. & N.A. & N.A. & 0.00 & - \\
\hline 1971 & N.A. & N.A. & N.A. & 0.00 & - \\
\hline 1972 & N.A. & $1.103 e-02$ & N.A. & 0.00 & - \\
\hline 1973 & $5.600 \mathrm{e}-03$ & $2.640 \mathrm{e}-03$ & N.A. & 0.00 & - \\
\hline 1974 & $5.400 \mathrm{e}-04$ & $6.000 e-05$ & N.A. & 0.00 & - \\
\hline 1975 & $1.078 \mathrm{e}-03$ & $8.900 \mathrm{e}-05$ & N.A. & 0.00 & - \\
\hline 1976 & $2.110 \mathrm{e}-03$ & $1.960 \mathrm{e}-04$ & N.A. & 0.00 & - \\
\hline 1977 & $1.690 \mathrm{e}-03$ & $4.100 \mathrm{e}-05$ & N.A. & 0.00 & - \\
\hline 1978 & $1.570 \mathrm{e}-03$ & $2.800 e-05$ & N.A. & $4.840 \mathrm{e}-05$ & - \\
\hline 1979 & $1.307 e-03$ & $2.100 \mathrm{e}-05$ & N.A. & $1.370 e-05$ & - \\
\hline 1980 & $1.744 \mathrm{e}-03$ & $6.000 \mathrm{e}-06$ & $2.000 \mathrm{e}-06$ & $1.000 \mathrm{e}-05$ & - \\
\hline 1981 & $3.263 e-03$ & $1.860 \mathrm{e}-04$ & $1.000 \mathrm{e}-06$ & $6.340 \mathrm{e}-04$ & - \\
\hline 1982 & $3.080 \mathrm{e}-03$ & $3.160 \mathrm{e}-04$ & $1.300 \mathrm{e}-05$ & $3.720 \mathrm{e}-04$ & - \\
\hline 1983 & 0.00 & $5.260 \mathrm{e}-04$ & $4.730 \mathrm{e}-04$ & 0.00 & - \\
\hline 1984 & 0.00 & $5.890 \mathrm{e}-04$ & $1.000 \mathrm{e}-06$ & $1.700 \mathrm{e}-05$ & - \\
\hline 1985 & 0.00 & $7.440 \mathrm{e}-04$ & 0.00 & 0.00 & - \\
\hline 1986 & 0.00 & $5.000 \mathrm{e}-05$ & 0.00 & $4.000 \mathrm{e}-06$ & - \\
\hline 1987 & 0.00 & 0.00 & 0.00 & $2.000 \mathrm{e}-06$ & - \\
\hline 1988 & 0.00 & 0.00 & 0.00 & $1.900 \mathrm{e}-05$ & - \\
\hline 1989 & 0.00 & $1.720 \mathrm{e}-04$ & 0.00 & 0.00 & $1.820 \mathrm{e}-04$ \\
\hline
\end{tabular}

* Based on specific radiochemical analyses for uranium

$\dagger \quad$ Based on gross alpha analyses

N.A. Not analyzed

ETF not operational until 1989 
Chapter 3.

Uranium Concentrations and Transport at SRS 


\section{Surface Water Transport Of Uranium}

Almost all of the Savannah River Site (SRS) is drained by tributaries of the Savannah River: Upper Three Runs Creek, Beaver Dam Creek, Four Mile Creek, Pen Branch, Steel Creek, and Lower Three Runs Creek (see Figure 3-1). Each of these tributaries receives process water from SRS facilities. Only one, small, unnamed stream in the northeastern sector of the site drains to the Salkehatchie River to the east (no SRS facilities discharge to this stream).

The sources of surface water on the site are rainfall, ground water, and process water discharges. Most of the process water comes from the Savannah River and is used to cool SRS nuclear reactors. The cooling water is discharged to streams or lakes that flow back to the river. Additional lesser amounts of process water are drawn from wells and then discharged to SRS streams. Minor volumes of water come from natural springs and seepage basin outcrops.

Since SRS began operation in 1954, significant amounts of uranium have been released to SRS streams. Most of the uranium releases occurred from the nuclear fuel fabrication facility, known as M Area. The M Area is used for fabricating the nuclear fuel assemblies for use in SRS reactors. Process effluents from other SRS facilities (such as the nuclear reactors, chemical separations, and laboratories) contribute only a small fraction of the uranium discharged to surface waters at SRS.

Uranium from naturally occurring sources is also present in SRS surface waters. Uranium is released from rocks and

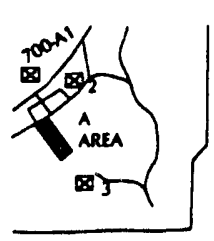

Upper Tims Branch

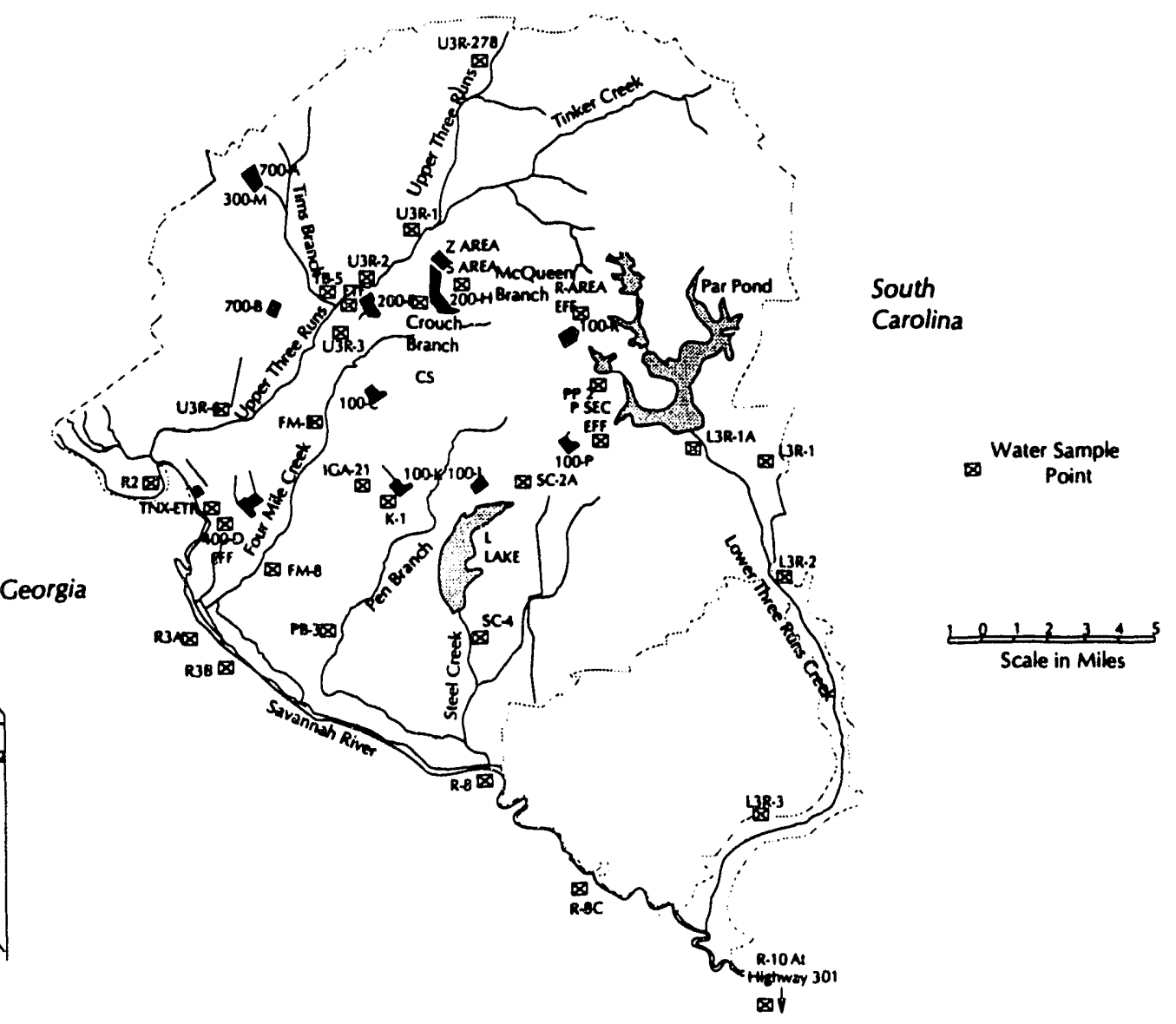

Figure 3-1. Surface Water Monitoring Locations 
minerals during the process of weathering, and this uranium may be trensported long distances by surface waters. Background surface water uranium concentrations range from 0.01 to less than ten parts per billion, depending on rock and mineral uranium concentration and weathering.

\section{Monitoring for Uranium in SRS Streams and the Savannah River}

SRS streams and facility effluents are monitored for uranium by measuring gross alpha ectivity concentrations, U/Pu alpha measurements, metal specific determinations, or a combination of these techniques (Figure 3-1 and Environmental Reports).

Gross alpha activity is measured by evaporating a known volume of water on a planchet and counting all alpha activity in an alpha counter. Gross alpha activity measures the total amount of alpha emitting activity from natural and manmade radionuclides, but does not indicate the identity of the source radionuclide(s). Beginning in 1974, U/Pu extractions were made on water samples from several locations to more accurately determine the aynount of $U / P u$ that is present in the sample. Gross alpha and U/Pu activity measurements are now being supplemented by non-radiological techniques (fluorescence analysis) to measure the actual amount of uranium present in SRS streams.

\section{Releases of Uranium to SRS Streams}

Gros, alpha measurements have been used since SRS startup in 1954 to provide estimates of uranium and other radionuclide releases. The radionuclides that make up the gross alpha activity measurement in process effluents vary with the SRS operating area. SRS has followed the policy stating that if the major alpha emitting radionuclide is known in a process effluent, then the gross alpha activity is reported as that radionuclide. If the radionuclides are not known, the gross alpha activity is reported as unidentified alpha (Cummings et al., 1991).

Greater than $97 \%$ of the gross alpha activity released from SRS facilities occurred from M Area (Figure 3-2). In the M Area, the alpha activity $(24.6 \mathrm{Ci})$ in the process effluent has been identified as essentially all depleted uranium. All other SRS facility releases constitute the remaining $3 \%$ and this alpha activity could come from any number of radionuclides: uranium, transuranics, and natural radionuclides contained in the process cooling water obtained from the Savannah River and wells. (Cummings et al., 1991)
The focus of this review will be the Tims Branch system, since $97 \%$ of the uranium released at SRS was discharged to this stream. Other SRS streams will be reviewed as a unit because it is difficult to differentiate the extremely small amounts of uranium.

\section{Uranium in SRS Streams}

\section{Tims Branch, A Tributary of Upper Three Runs}

Upper Three Runs Creek is the only SRS stream with headwaters arising off the site. The stream is $40 \mathrm{~km}$ long and drains an area of about $545 \mathrm{~km}^{2}$. Its main tributaries are Tinker Creek and Tims Branch. Upper Threc Runs Creek has the largest natural flow of any plant stream. The avesage flow of $257 \mathrm{ft}^{3} / \mathrm{s}$ is slightly increased by a site contribution of less than $10 \mathrm{ft}^{3} / \mathrm{sec}$.

SRS facilities that drain into Upper Teree Runs Creek include M Area, the Sevannah River Laboratory, and F-Area storm and asil basin flows. Beginning in 1988, the Effluent Treatuent Facility in $\mathbf{H}$ Area began releasing process water directiy into Upper Three Runs Creek. Of the SRS facilities whose effluents drain to L 'pper Three Runs Creek, $M$ Area has released the most ilpha activity (uranium). Thri ilpha activity was discharged into a process drainage ditch that nlowed into Tims Branch, and Tims Branch drains into Upper Three Runs Creak (see Figure 3-1).

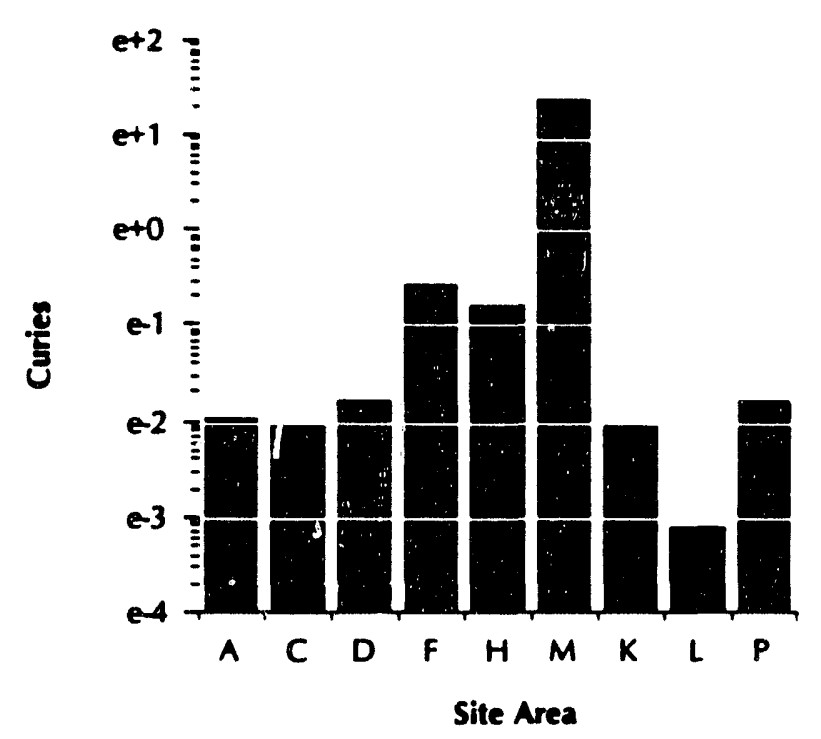

Figure 3.2. Curies of A pha Activity Releases by SRS Areas 


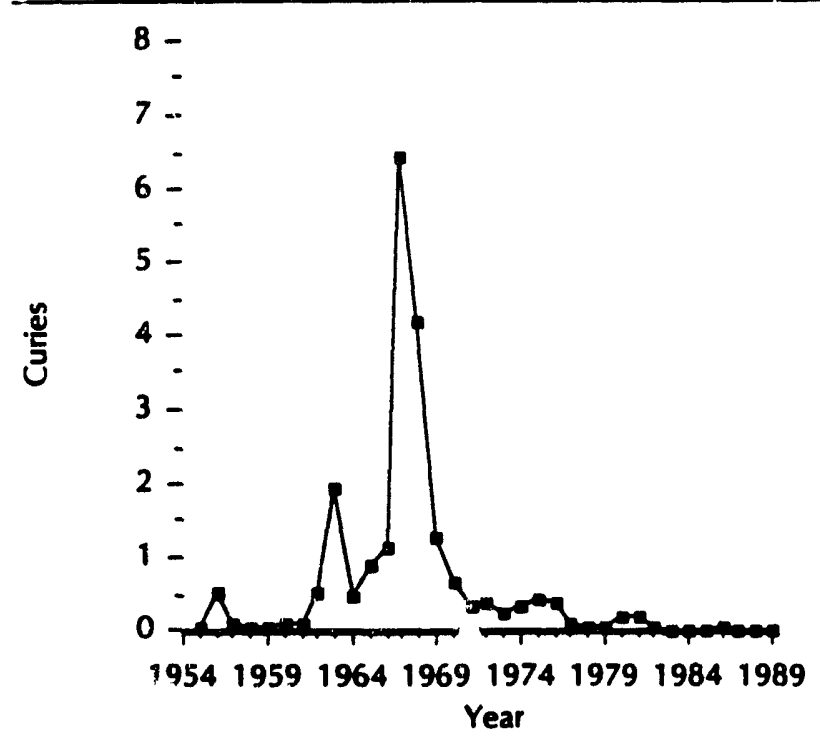

Figure 3-3. Curies of Alpha Activity Released to Tims Branch from M-Area Operations

About 25 curies oi gross alpha activity have been discharged to Tims Bianch from the $M$ Area fuel/target fabrication fucilitic since SRS startup (see Figure 3-3). Most of the alpha autivity (uranium) was released between 1966 and 1969 during the ilevelopment of an new uranium/aluminum bondirg prucess for fuel and target assemblies.

The sourci of the alpha activity vras waste from cleaning and recuvery operations and testing in $M$ Area. In the process of making thr fret or target elements, uranium slugs were cl earrea in step operations with chlcrinated hydrocarbon solvents, nitric, phosphoric, and hydrochloric acids. The cleaning removed alpha activity (uranium) from the surfaces of the slugs used to fabricate target elements. The used chemicals from this fleaning operation were treated and the waste water containing traces of residual alpha activity released. Alpha activity was also released from target elements that failed specifications or tests. The waste water from all of these sources entered a drainage ditch to Tims Branch near the 700 Area waste water treatment plant on Road D (see Figure 3-1). Since 1985, an advanced liquid waste water treatment facility (LETF) has been in operation in $M$ Area and uranium releases have been reduced by a factor of 100 to 1000 .

The mass of uranium released from M Area to Tims Branch was estimated to be about 96,000 pounds since plant startup. This estimate was made by converting curies of alpha activity released to Tims Branch to mass of uranium. The alpha specific activity of uranium is the ratio of alpha activity to the mass of uranium required to produce that amount of alpha activity. The alpha activity was corrected for alpha self absorption by applying a correction factor obtained from U/Pu analysis.

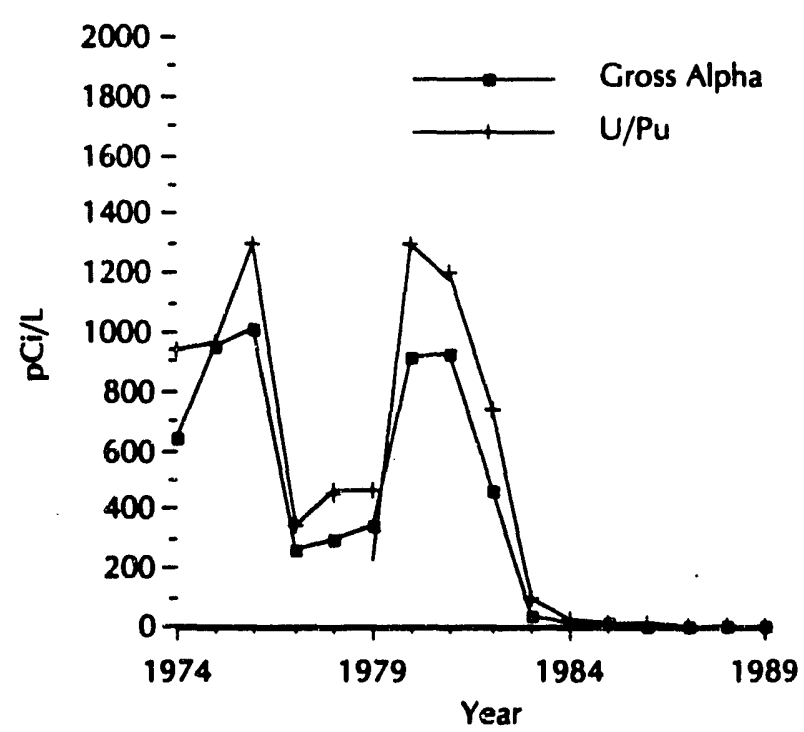

Figure 3-4. Gross Alpha Activity and U/Pu Activity in MArea Outfall

Gross alpha measurements are subject to error in estimating the amount of uranium that may be present in a sample due to the presence of other alpha sources and self absorption. To reduce this error, measurements of U/Pu began in 1974 in the water released to Tims Branch from $M$ Area operations. $\mathrm{U} / \mathrm{Pu}$ removes other alpha-emitting radionuclides and reduces the effect of self-absorption during counting. Comparison of gross alpha measurements to U/Pu alpha measurements since 1974 show that the gross alpha activity measurements were less than U/Pu measurements (see Figures 3-4 and 3-5) and that the gross alpha measurements should be increased by $25 \%$.

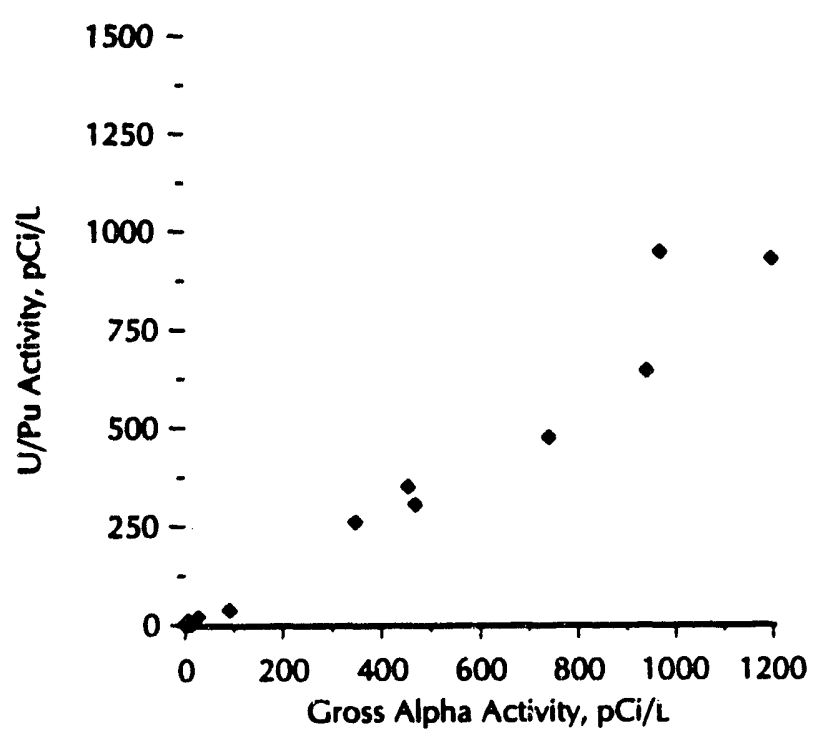

Figure 3-5. Gross Alpha Activity vs. U/Pu Activity in MArea Outfall 


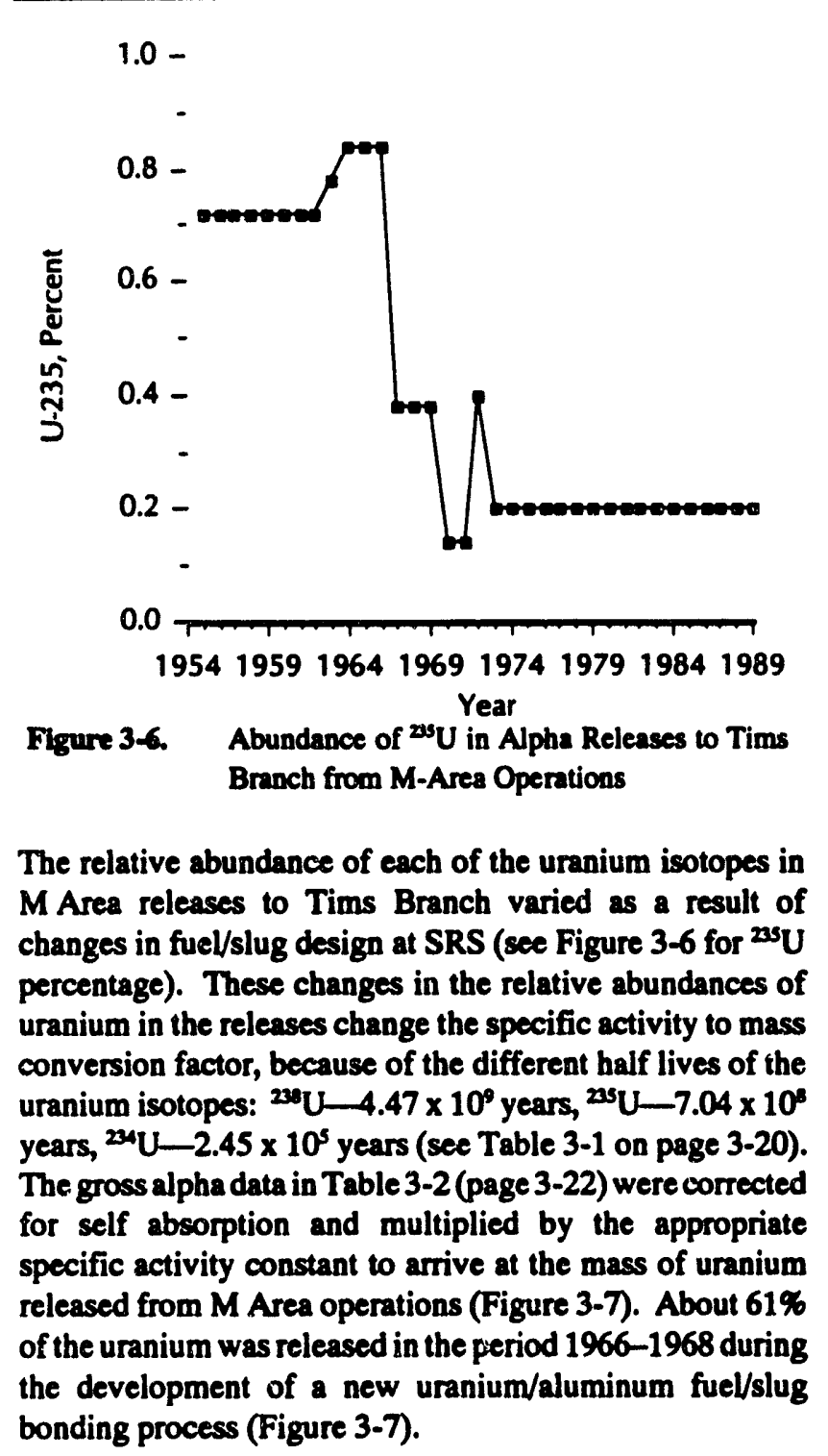

\section{Amount of Uranium in Tims Branch System}

Comparison of the gross alpha activity released at the discharge point from $M$ Area to the gross alpha activity in Upper Three Runs Creek below the confluence with Tims Branch at Road C shows that most of the alpha activity is still in the Tims Branch system (Figure 3-8). Even during years of peak alpha activity discharges from $M$ Area, the gross alpha activity in Upper Three Runs Creek below the confluence with Tims Branch remained nearly constant (Figure 3-8), showing that most of the alpha activity was deposited in the Tims Branch system. The actual $M$ Area alpha activity contributions to Upper Three Runs Creek cannot be accurately evaluated because the gross alpha activity concentrations in Upper Three Runs Creek have remained at or near background alpha activity concentrations. Sec the comparison of gross alpha activity measure-

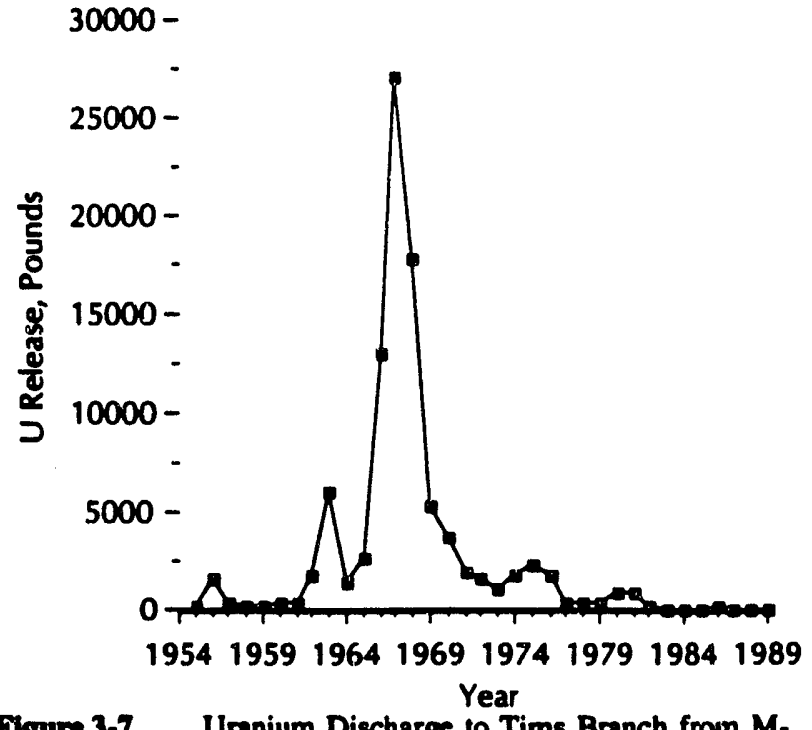

Figure 3-7. Uranium Discharge to Tims Branch from MArea Operations

ments in Upper Three Runs Creek at Road F above the Tims Branch confluence and Rosd C below Tims Branch in Figure 3-9. It is estimated that nearly all of the estimated 96,000 pounds of uranium released from M Area operations remains in the Tims Branch system.

\section{Location of Uranium and Morphology of the Tims Branch System}

The recently completed aerial radiological survey of the Tims Branch system by EG\&G shows that the locations of the major deposition areas for uranium from the $M$ Area

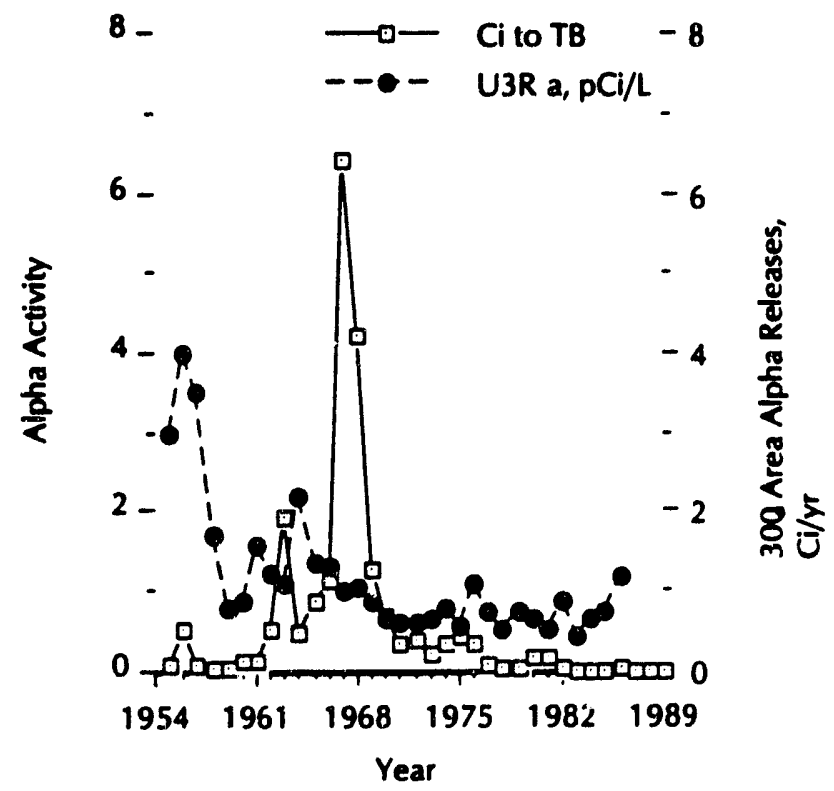

Flgure 3-8. Alphs Activity in Upper Three Runs Creek vs. M-Area Alpha Releases 
Chapter 3. Uranium Concentrations and Transport at SRS

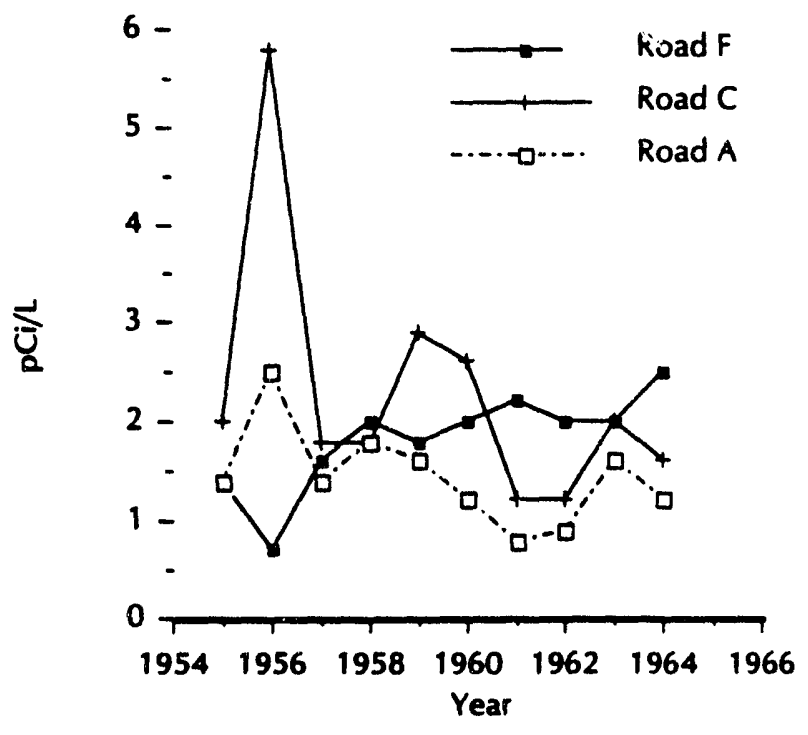

Figure 3-9. Alpha Activity in upper Three Runs Creck at Road A, Road C, and Road F discharges are from the entrance of $M$ Area effluents into Tims Branch to Steed Pond(Figure 3-10). The area between Steed Pond and Upper Three Runs Creek did not show the presence of ${ }^{238} \mathrm{U}$, except in the lower part of Tims Branch at the site of an old pond. The ${ }^{238} \mathrm{U}$ is identified by the presence of ${ }^{234 \mathrm{ma}} \mathrm{Pa}$, decay chain daughter of ${ }^{236} \mathrm{U}$.

The conditions for deposition of uranium in Tims Branch are influenced by stream morphology. The discharges from the M Area enter a drainage ditch adjacent to Road D and the railroad track and flow down a rather steep slope that intersects Tims Branch (Figure 3-1). Over the years considerable erosion has occurred in this ditch as it adjusted to increased flows from $M$ Area and to increased peak storm flow due to large buildings and paved areas draining into the ditch. The erosion in the ditch prevented the deposition of uranium in the ditch. At the bottom of this slope, most of the eroded sediment and some of the released uranium was deposited in a small delta in the floodplain of Tims Branch at

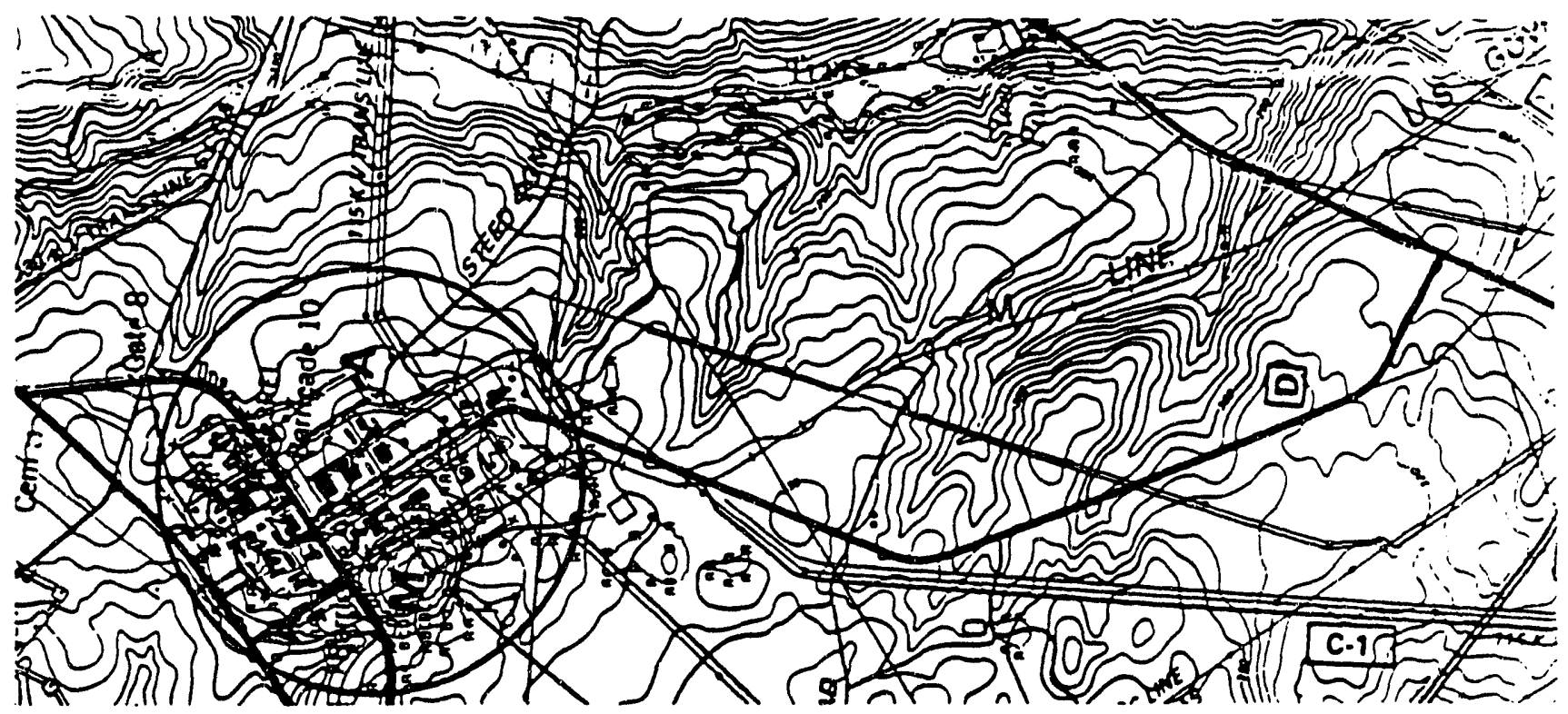

Figure 3-10. Aerial Survey 


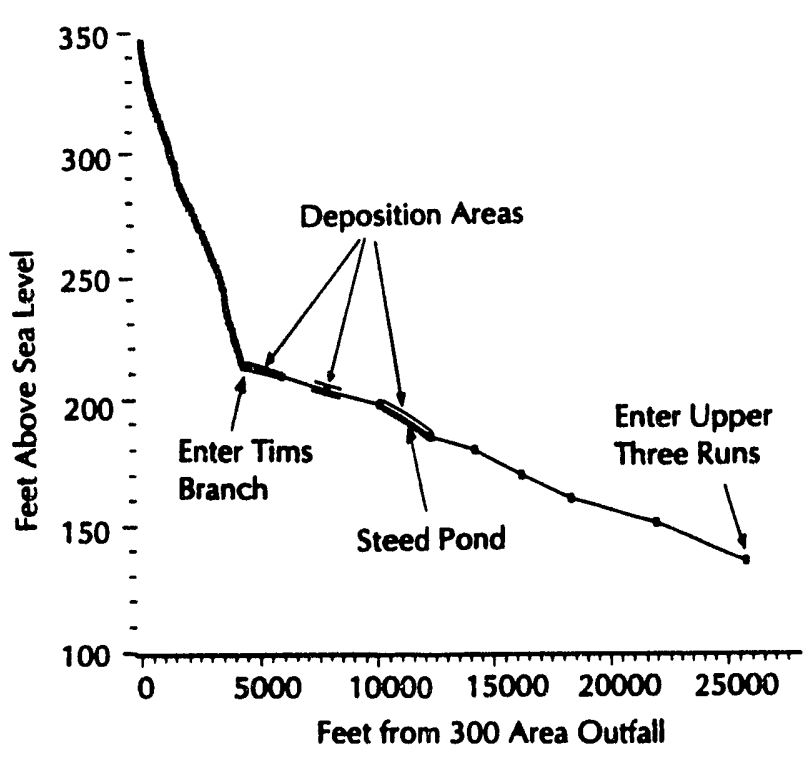

Figure 3-11. Elevation of Tims Branch System from M-Area Outfall to Upper Three Runs Creek

the intersection. The abrupt change in slope at this point (3\% to $0.4 \%$ ) reduced the capacity of water to carry the sediment, so this was where most of the eroded sediment was deposited (Figure 3-11).

From the delta, the water flows at a low slope of $0.4 \%$ for a distance of about of $\mathbf{5 8 0 0}$ feet before it enters Steed Pond. Several beaver dams have existed over the years between the delta and Steed Pond, which provides settling locations for the deposition of fine grain sediments and uranium (Figure 3-10).

Steed Pond acted as a settling basin for Tims Branch. Water entering the pond had a residence time of about 3 days (Hayes, 1984). This residence time was sufficient for the settling of alpha activity as evidenced by aerial surveys. An accumulation of about 3 feet of sediment in the vicinity of the Steed Pond spillway shows the result of sediment deposition.

Steed Pond originally had an area of about 14 acres, and an area of about 11 acres when the spillway gave way in September 1984. In the early 1960s, part of the spillway was collapsed and the pond partially drained. Based on aerial photos, the pond still had a few acres of water in 1966 indicating that the spillway was only partially removed. In the early 1970s, the spillway was repaired and the pond returned to a surface area of about 11 acres. Because the spillway has never been completely removed, the pond has functioned as a sediment trap with varying efficiencies based on the amount of water in the pond. In 1984, however, the spillway again collapsed and the pond drained completely. It remains dry at present.

\section{Concentration of Uranium in the Sediments of Tims Branch}

Radiological and nonradiological measurements for uranium have been made in the sediments of the Tims Branch system (Pickett, 1990 and Starkle et al., 1987). Until 1985, uranium measurements in the sediments were made by counting the samples for uranium radioactivity. Counting methods are not as sensitive or as accurate as most chemicalinstrumental methods, due to counting limitations. Comparisons between radiological (pCi/g) and nonradiological $(\mathrm{mg} / \mathrm{g})$ concentrations will not be made because the uranium isotopic compositions were not measured.

The first survey for uranium in sediments from the Tims Branch system was made in Steed Pond (6 cores) in 1966 (Pickett, 1990). Greater then 95\% of the uranium in Steed Pond was in the upper 6 inches of sediment. The uranium concentrations ranged from 20 to $531 \mathrm{pCi} / \mathrm{g}$ in the upper 6 inches of sediment (Pickett, 1990). Between 6 and 12 inches depth, the uranium radioactivity had decreased to about $1 / 8$ the surface value and between 12 and 24 inches depth, the uranium concentration was near background concentrations (about $5 \mathrm{pCi} / \mathrm{g}$ ).

In 1977, a second radiological survey of Tims Branch and Steed Pond was conducted for uranium and thorium. The data indicated no detectable levels of thorium and uranium in Tims Branch above its confluence with the $M$ Area effluent discharge ditch. Cores from the M Area effluent ditch, and from the braided streams in Tims Branch downstream of the M Area effluent confluence, contained from 10 to $27 \mathrm{pCi} / \mathrm{g}$ of uranium and from 4 to $13 \mathrm{pCi} / \mathrm{g}$ of thorium.

The two sediment cores collected from Steed Pond in 1977 did not have uranium or thorium concentrations above background. However, these cores were taken at the edge of the pond and would not reflect deposition in the deeper portions of the pond.

Extensive sediment sampling was performed following the failure of Steed Pond's wooden spillway in August 1984. Sediment core samples were collected from Steed Pond and Tims Branch upstream of Stced Pond (En. Rp. 86-30-2). A total of 30 cores were taken in the Tims Branch system-15 from Steed Pond and 15 between Steed Pond and the M Area effluent ditch (see Figure 3-12). More sensitive and 


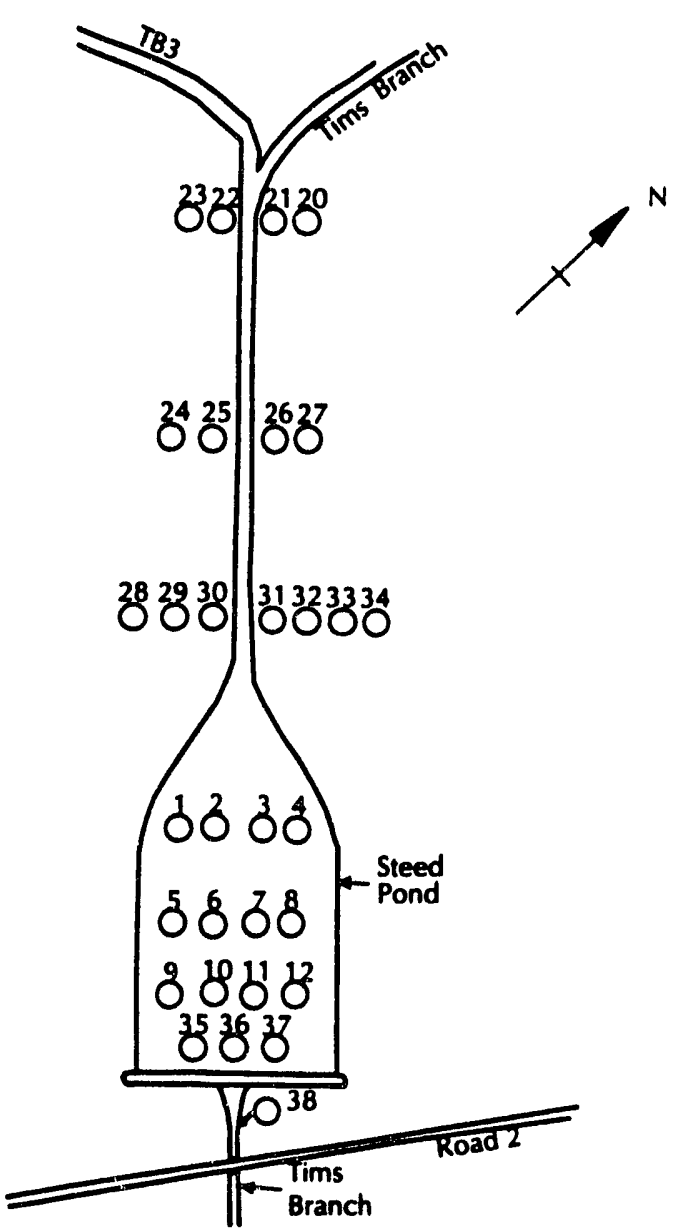

Figure 3-12. Steed Pond's Soil Core Locations

accurate nonradiological methods were used to measure the uranium concentration in the sediments in 1984.

Steed Pond uranium sediment concentrations averaged $60 \%$ higher than the sediments above Steed Pond (Table 3-3 on page 3-23). The higher concentrations result from the longer residence time for water in Steed Pond as compared to the shallow beaver dam ponds and channel flow above Steed Pond. The longer residence times allowed more time for suspended solids to settle or sorption reactions to occur. Uranium concentrations ranged from $0.9 \mu \mathrm{g} / \mathrm{g}$ (background) to $6,165 \mu \mathrm{g} / \mathrm{g}$ in the sediments of Steed Pond and $1.7 \mu \mathrm{g} / \mathrm{g}$ (background) to $3,570 \mu \mathrm{g} / \mathrm{g}$ above Steed Pond. Uranium concentrations in sediments of the Tims Branch system are much higher than those of other small streams in the Savannah River watershed which average about $14 \mu \mathrm{g} / \mathrm{g}$ (Faye and Hayes).

Uranium depth concentration profiles show that most of the uranium is in the upper 6 inches of sediment (Figures 3-13 and 3-14). In the 1984 Steed Pond survey, the percent of

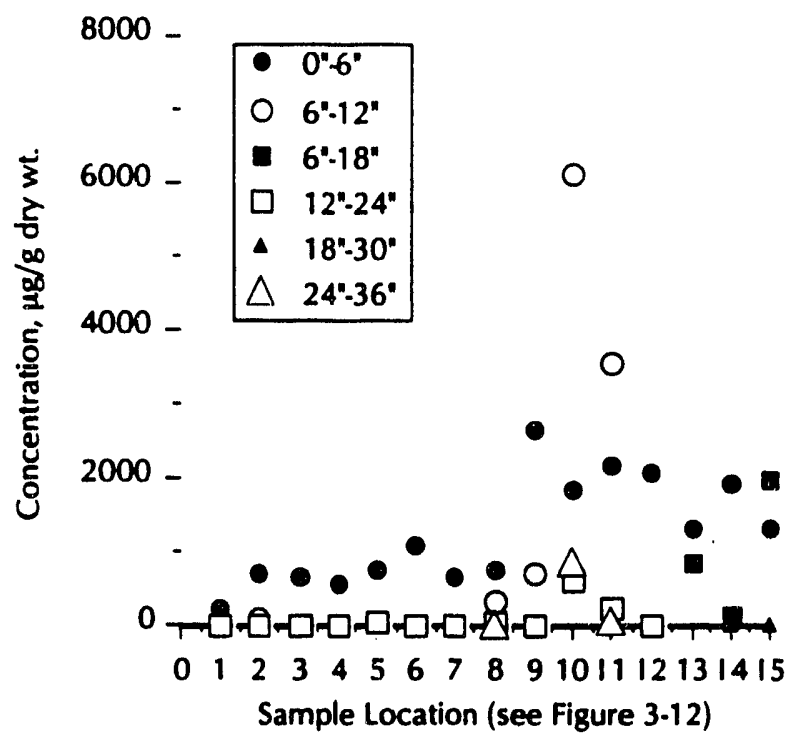

Figure 3-13. Uranium in Steed Pond Cores, 1984 Survey

uranium in the upper 6 inches of sediment had decreased from $90 \%$ to $58 \%$ of the total. This decrease probably reflects an increase in sediment deposition in Steed Pond between the 1966 and 1984 surveys.

In 26 of the cores the sediment uranium distribution looked normal, in that the highest concentration was in the upper 6 inches and decreased with increasing depth. In the other four cores, the highest uranium concentration was in the fraction below 6 inches. In fact, the 3 highest uranium concentrations in the 30 cores occurred in the sediment fraction below 6 inches in Steed Pond and above Steed Pond in Tims Branch (Figures 3-13 and 3-14).

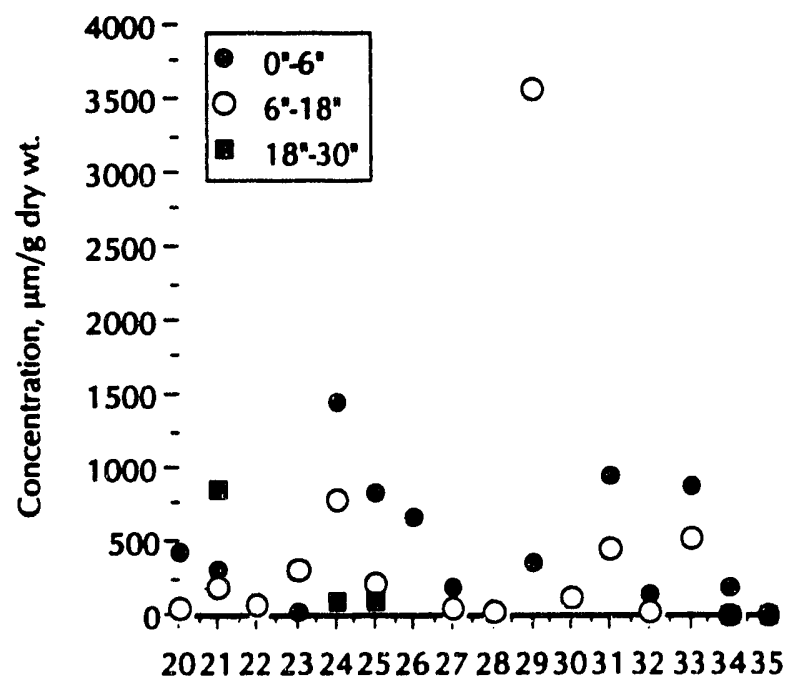

Sample Location (see Figure 3-12)

Figure 3-14. Uranium in Tims Branch Cores above Steed Pond, 1984 Survey 
To understand the cause for the higher uranium concentrations at depth in the sediments below 6 inches would require a detailed study of the cores. Some of the processes involved in determining depth distributions include: deposition, erosion, and redeposition; size sorting during deposition; changes in the flow regime; flood events; manmade changes; changes in water level in a pond; biological processes; alterations in water chemistry; and unplanned releases.

\section{Inventory of Uranium in Steed Pond}

The inventory of uranium in Steed Pond was estimated to be about 67,730 pounds using the 1984 sediment survey data (Table 3-3 on page 3-23) and an area of 13 acres. This rough estimate indicates that about $70 \%$ of the uranium released from 300 Area operations might be located in Steed Pond. More thorough sampling of Steed Pond is needed to substantiate this inventory. Uranium inventory for the rest of the Tims Branch system was not estimated, because of the limited data available.

\section{Upper Three Runs Creek}

Both radiological and nonradiological monitoring for uranium have been made in Tims Branch and in Upper Three Runs Creek below the confluence with Tims Branch. Gross alpha monitoring in Upper Three Runs began in 1955 and continues to the present. Early monitoring in Tims Branch focused on the areas near $M$ Area and monitoring in the lower reach was not started until 1972 (the monitoring site identified as TB $\# 5$ in Figure 3-1). Beginning in 1984, routine nonradiological measurements for uranium were started in Tims Branch.

Results from gross alpha monitoring in Upper Three Runs Creek, below the confluence with Tims Branch, show little impact from M Area operations (Figure 3-15). The reason M Area operations have had so little impact on gross alpha concentrations in Upper Three Runs Creek is because of deposition of most of the uranium from $M$ Area operations in the Tims Branch system, and to the fifty fold dilution of Tims Branch water after it enters Upper Three Runs Creek $\left(5 \mathrm{ft}^{3} / \mathrm{sec}\right.$ vs. $\left.257 \mathrm{ft}^{3} / \mathrm{sec}\right)$.

The decreasing gross alpha concentrations measured in Tims Branch (Tims Branch \#5) near its confluence with Upper Three Runs Creek reflects the decreasing releases from M Area operations (Figure 3-15). Since 1983, the gross alpha concentrations at Tims Branch $\# 5$ have been indistinguishable from gross alpha concentrations in Upper Three Runs Creek (Figures 3-15 and 3-16), showing the

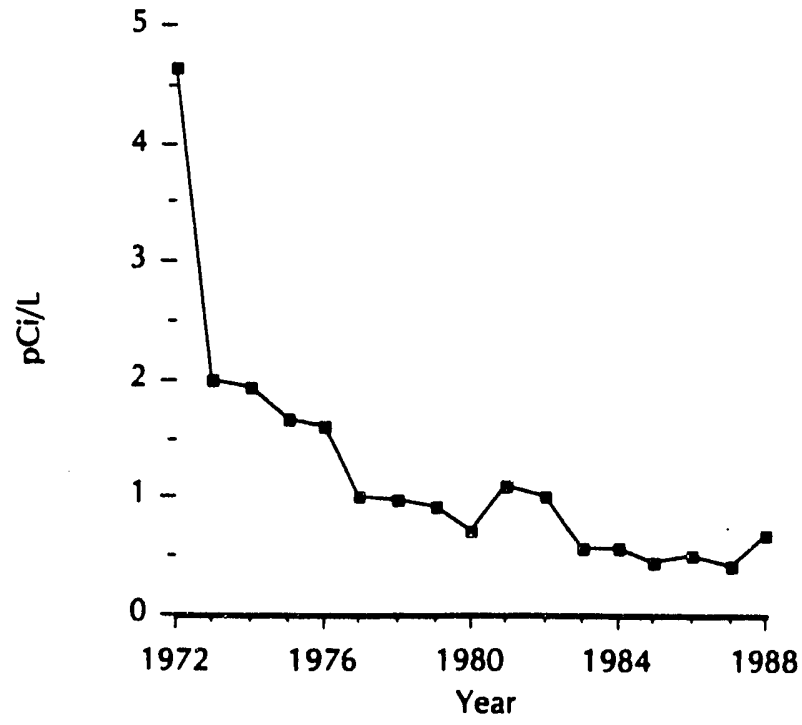

Figure 3-15. Gross Alpha Activity in Tims Branch at TB\#5

impact of reduced releases, the start of operation of the effluent treatment facility in M Area, and that uranium in Tims Branch sediment is not remobilizing appreciably into the waters of Tims Branch.

Nonradiological uranium measurements $(\mu \mathrm{g} / \mathrm{g})$ began in 1984 at Tims Branch \#5 following the partial collapse of the Steed Pond spillway and continue to present. These results show that the uranium concentration averages about $4.2 \mathrm{ppb}$ $(\mu \mathrm{g} / \mathrm{l})$ or about $20 \%$ of the proposed drinking water concentration guide of $20 \mathrm{ppb}$ (Federal Register, July 1991) (Figure 3-16). Uranium concentrations in Tims Branch are higher than in the Savannah River and other background streams by a factor of 80 , which reflects the influence of

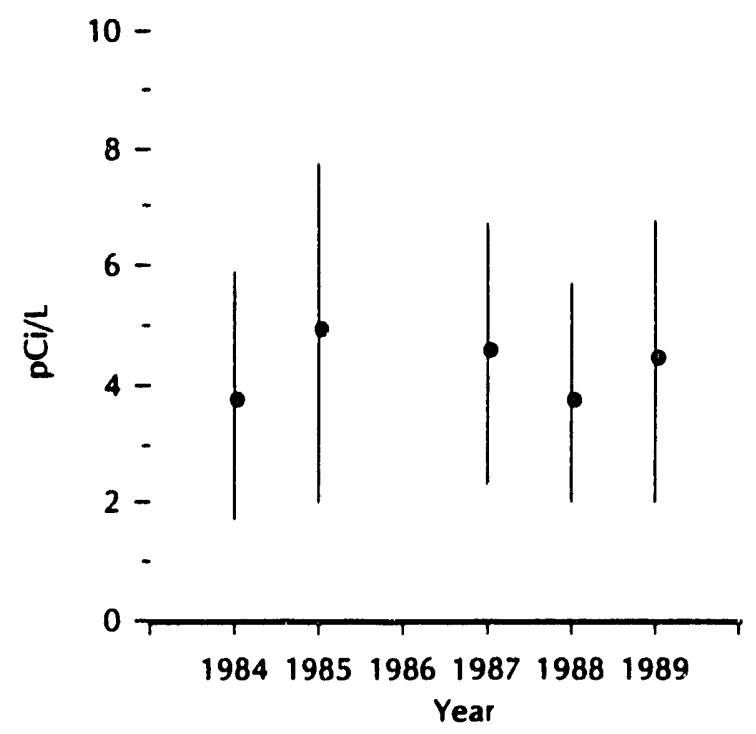

Figure 3-16. Uranium Concentrations Near the Mouth of Tims Branch 


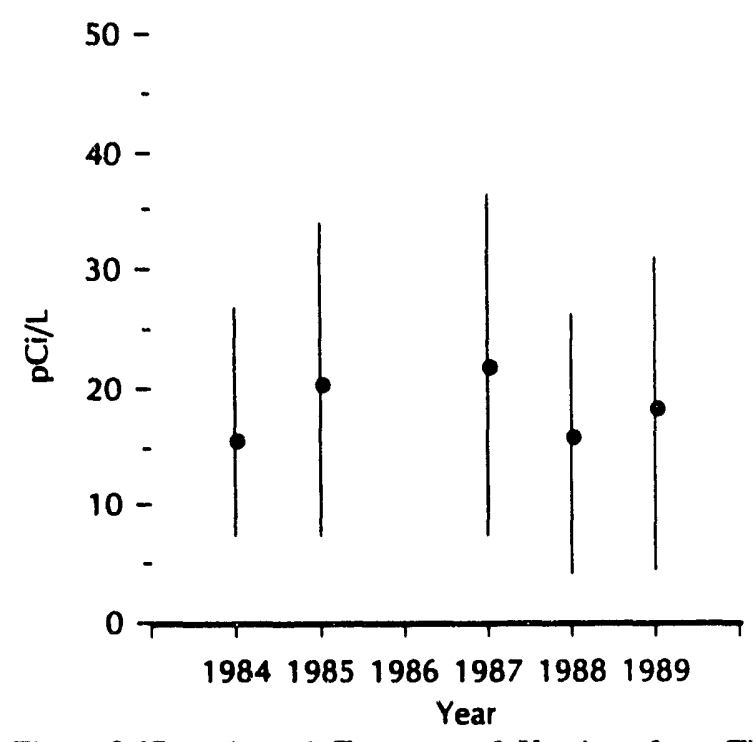

Figure 3-17. Annual Transport of Uranium from Tims Branch to Upper Three Runs Creek

M-Area uranium releases. Uranium from Tims Branch is diluted by a factor of 50 after it mixes with Upper Three Runs Creek. After mixing, the uranium concentration in Upper Three Runs Creek is increased from $0.05 \mathrm{ppb}$ to about $0.2 \mathrm{ppb}$ or $1 \%$ of the proposed drinking water guide.

Tims Branch uranium concentration measurements were used to estimate uranium loss rates from the Tims Branch system to Upper Three Runs Creek. The loss rate from Tims Branch system to Upper Three Runs Creek was estimated to be about 44 pounds/year ( $20 \mathrm{~kg} /$ year, Figure 3-17), which would include the small uranium releases from $M$ Area. This loss rate indicates that the uranium is remobilizing at an extremely low rate to Upper Three Runs Creek and that the

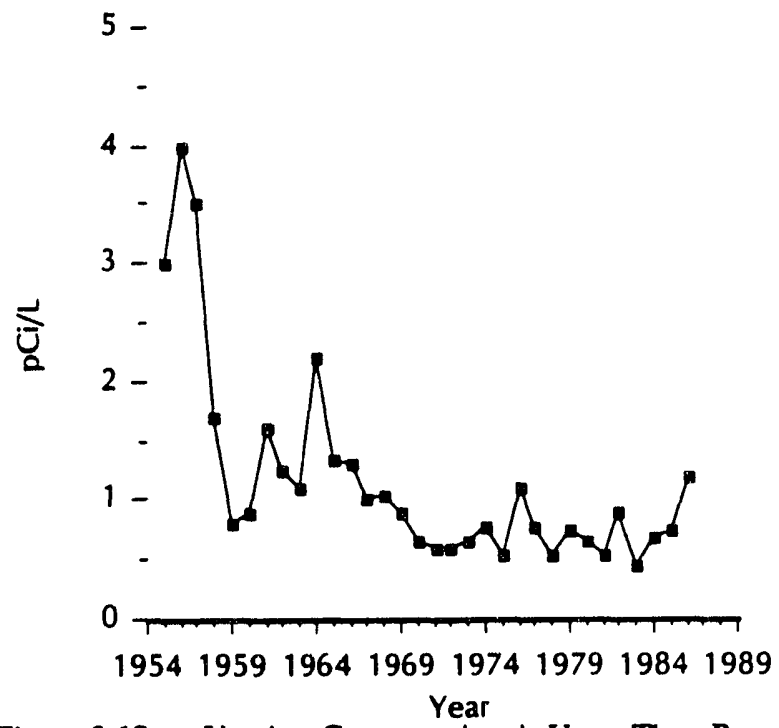

Figure 3-18. Uranium Concentrations in Upper Three Runs Creek

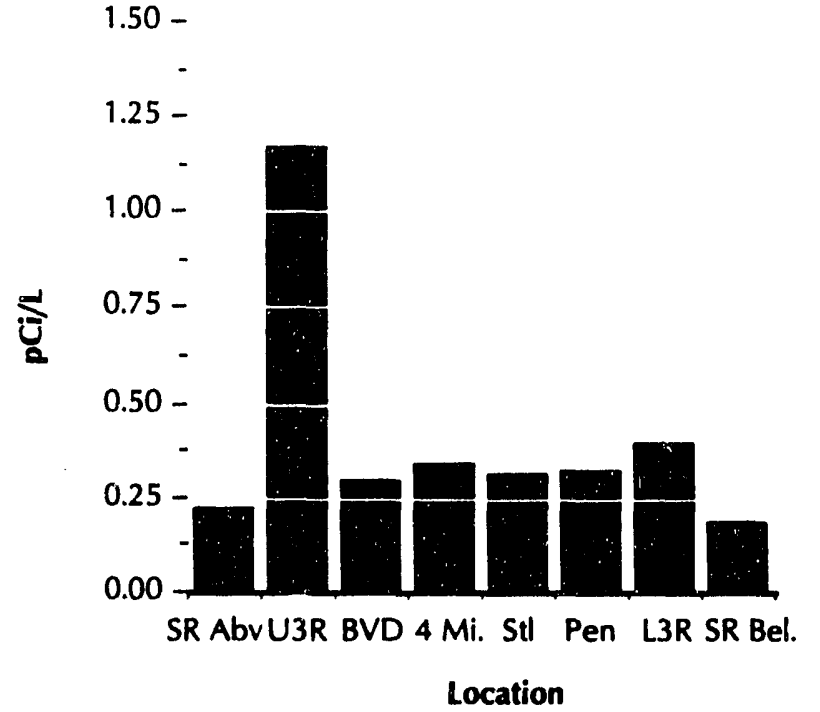

Figure 3-19. Average Gross Alpha Concentrations in SRS Streams and the Savannah River

uranium will remain in the system a long time before it is slowly delivered to Upper Three Runs Creek. A residence time of about $\mathbf{2 0 0 0}$ years is calculated for the uranium now in the Tims Branch system $(96,000$ pounds/44 pounds/ year). This low loss rate results from the stability of the sediments and the securing of the sediments by the abundant floodplain vegetation.

\section{Other SRS Streams and the Savannah River}

Greater than $97 \%$ of the alpha activity released from SRS facilities was discharged from M Area (Figure 3-2). The remaining $3 \%$ and this alpha activity could come from any number of radionuclides: uranium, transuranics, and natural radionuclides contained in the process cooling water obtained from the Savannah River and wells. With the exception of Upper Three Runs Creek (Figure 3-18), gross alpha monitoring results from all SRS downstream monitoring locations show that the alpha concentrations are at or near concentrations measured in offsite streams (Figures 3-19 and 3-20). These results indicate that uranium releases from other SRS facilities have a negligible impact on alpha concentrations in SRS streams and the Savannah River. Note that the gross alpha concentrations measured in the Edisto River are consistently higher than those measured in the Savannah River either upstream or downstream of the SRS (Figure 3-20). Since no tributaries of the Edisto river originate on the Savannah River Site, the activity in the Edisto must be due to naturally occurring radioactivity.

Nonradiological measurements for uranium in the mouth of SRS streams and the Savannah River were started in 1988. 


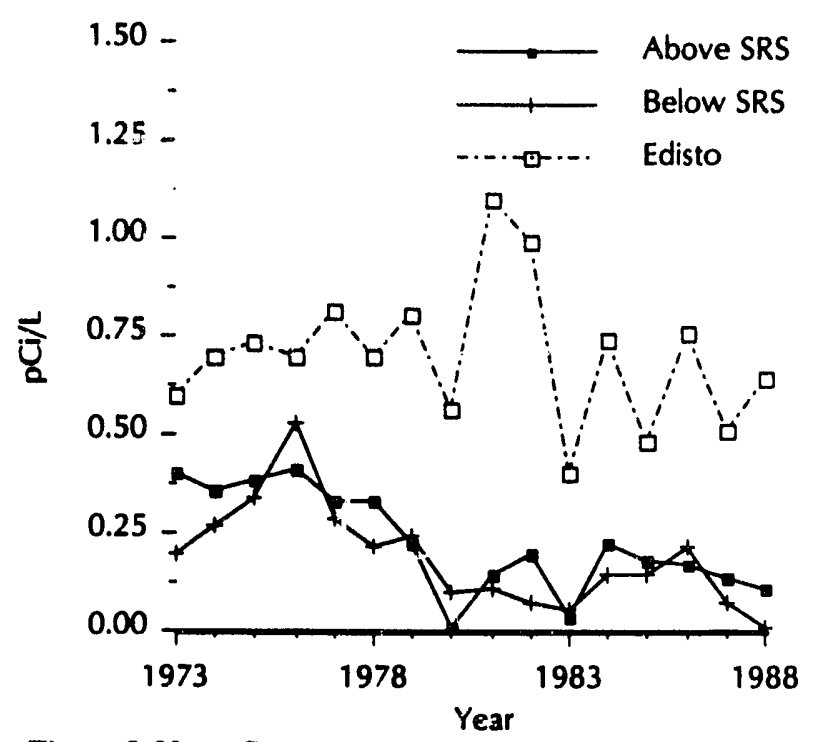

Figure 3-20. Gross Alpha Activity in the Savannah and Edisto Rivers

These results confirm the observations made from the gross alpha measurements, in that SRS operations (except $M$ Area) have little if any impact on stream uranium concentrations (Figure 3-21). The uranium concentration at the mouth of Upper Three Runs Creek is about $0.2 \mathrm{ppb}$ or about $1 \%$ of the proposed drinking water concentration guide of 20 ppb.

\section{Summary}

A review of the uranium releases from SRS facilities to the site streams show that $97 \%$ of the releases occurred from

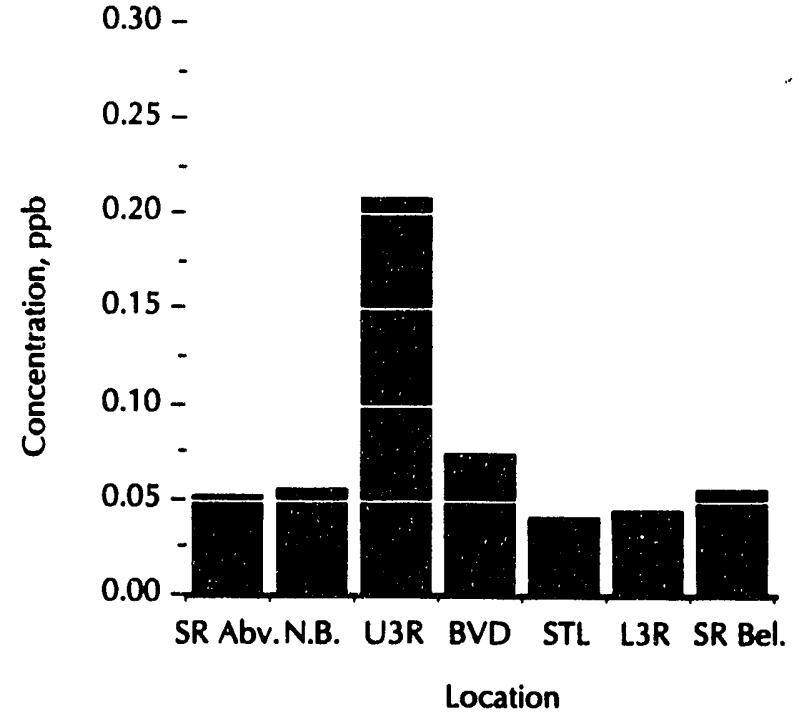

Figure 3-21. Concentrations in the Mouth of SRS Creeks, Savannah River, and Newberry Creek

M-Area operations and the remaining 3\% from all other SRS facilities. M Area operations released about $25 \mathrm{Ci}$ or 96,000 pounds to Tims Branch, a tributary of Upper Three Runs Creek, and most of that uranium remains in the sediments of the Tims Branch system. The loss rate of the uranium is extremely low from the Tims Branch system, and initial estimates, based on 6 years of data, indicate a residence time of $\mathbf{2 0 0 0}$ years. The uranium concentration in Tims Branch is about $4 \mathrm{ppb}$ (approximately $20 \%$ of the proposed drinking water guide of $20 \mathrm{ppb}$ ). Uranium concentrations in other SRS streams are at or near background concentrations ( $0.05 \mathrm{ppb})$. 


\section{Atmospheric Transport Of Uranium}

Concentrations of radioactive materials in the air are measured at five monitoring stations on the site, 14 monitoring stations at the site perimeter, and 12 stations at distances of approximately 25 miles from the center of the site (called 25-mile-radius stations). The site perimeter stations and the 25-mile-radius stations are strategically located to permit continuous sampling within each $30^{\circ}$ sector around SRS.

The locations of the monitoring stations were selected to optimize the probability of detecting the routine or nonroutine release of airborne radioactivity from the SRS regardless of wind direction. The locations of the air monitoring stations are shown in Figure 3-22.

Additional air monitoring stations are located in Savannah and Macon, GA, and in Columbia and Greenville, SC (100-mile-radius stations). These locations are so distant from the SRS that the contributions from SRS atmospheric releases to measured air concentrations are negligible. These stations serve as reference points for determining background radioactivity concentrations from natural sources and from worldwide fallout. Airborne radioactive materials are measured at the monitoring stations by drawing air samples through the appropriate air mediafilter paper, charcoal filters, and tritium absorbers. The

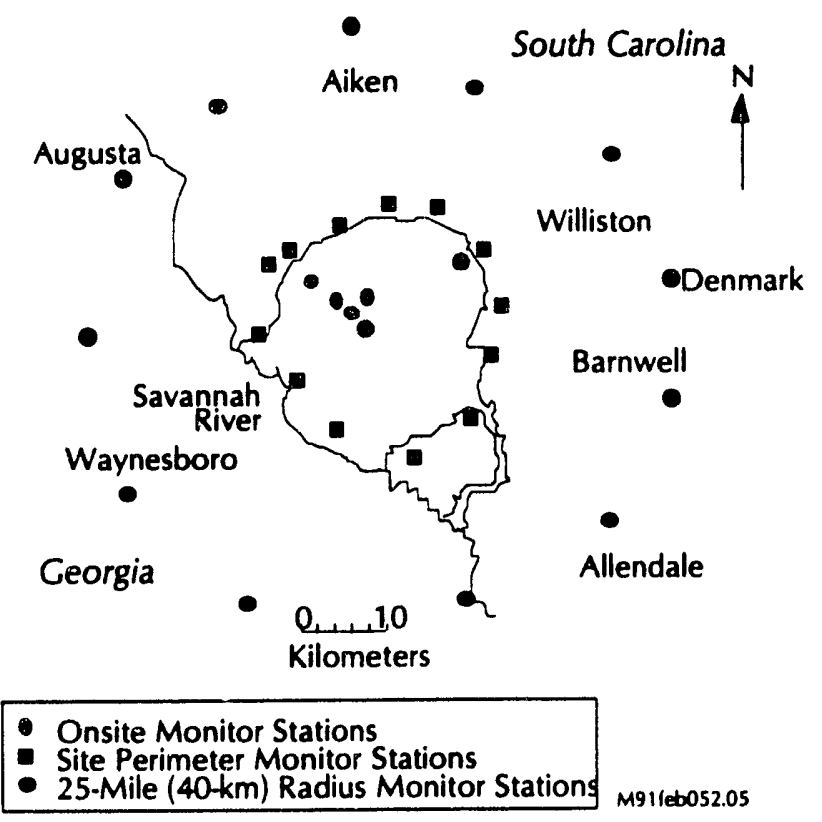

Figure 3-22. SRS Air Monitoring Locations filter papers and charcoal filters are collected and replaced weekly; the tritium absorbers are changed every two weeks. The collection media are then analyzed for radionuclide content. A complete discussion of the collection and analytical procedures can be found in Cummins, Martin, and Todd, 1990.

Historically, the concentrations of airborne alpha-emitting radionuclides in air samples around the SRS have been so low that specific radiochemical analyses for uranium in the air filters was not warranted. Uranium and thorium occur naturally in the soil and rocks in the region. As this naturally occurring radioactivity decays, daughter products are formed which are also radioactive. Both uranium and thorium have isotopes of the radicactive gas radon in their decay chain. Some of this radon gas escapes into the atmosphere where it contributes to the background airborne radioactivity. The concentration of this naturally occurring radioactivity varies from location to location and even with the time of day. Higher radon concentrations usually occur during atmospheric inversion conditions, typically in the early morning hours during the summer. Variations in the concentrations of naturally occurring radioactivity at the various monitoring locations tend to obscure potential SRS contributions to local airborne uranium activity.

The average total alpha activity measured in air at the various monitoring stations is shown in Figure 3-23 for

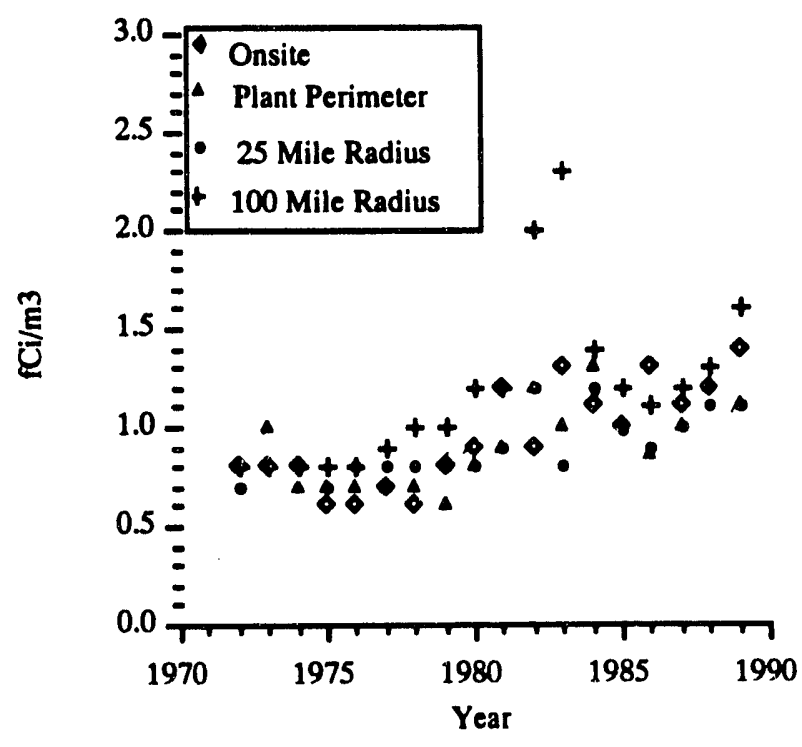

Figure 3-23. Gross Alpha Air Activity Around the SRS 
1972-1989. Examination of the figure shows that the concentration of gross alpha-emitting activity is frequently higher at the more distant monitoring stations than at any of the stations closer to SRS including onsite stations. This fact tends to confirm the conclusion expressed previously that local variations in naturally occurring radioactivity mask SRS releases of alpha-emitting radionuclides. Thus, potential contributions to offsite doses from SRS uranium releases must be calculated rather than measured as discussed in Chapter 5. 


\section{Groundwater Transport Of Uranium}

There is no indication that the uranium contamination in shallow groundwater aquifers at SRS has reached the public zone. The uranium in groundwater is generally confined to specific locations under waste management operating areas from which it travels toward surface streams with the normal flow of groundwater.

Primary factors in the confinement of uranium to groundwater are the size of the site and the local hydrological conditions. Because the contaminated areas are located near the center of the $753-\mathrm{km}^{2}$ site, there is a buffer zone of sufficient size to contain the uranium within the site boundaries until it outcrops into a site stream (Figure 3-1).

Uranium in groundwater results from past waste disposal practices that were consistent with general industry methods from the 1950 s to the early 1980 s. Sources of uranium in groundwater are principally wastewater released to earthen seepage basins, buried solid wastes and residues, and leachates that have percolated through the soil to the upper groundwater aquifers. SRS waste disposal practices significantly improved in the late 1980 s with the phase-out of seepage basin usage in all nonreactor facilities.

Uranium entering the groundwater system would be transported downgradient, forming a plume within the groundwater. This type of movement within the groundwater flow system is referred to as advection (or convection). The movement and mixing of uranium in the groundwater flow system are influenced by hydrodynamic dispersion, chemical adsorption, molecular diffusion, and chemical specie. The mechanical mixing results from velocity differences produced by heterogeneities in the physical system through which the groundwater moves and the tortuosity of the path traveled. Molecular diffusion occurs as the result of the molecular activity and is usually much less important than the effect of mechanical mixing. These two mixing processes cause a spreading of uranium in groundwater over a larger area than advection alone would produce, resulting in a dilution of uranium.

Uranium in groundwater may be complexed by, or react with, many constituents in the groundwater depending upon factors such as $\mathrm{pH}$, dissolved oxygen, complexing agents, etc. As a result, the mobility of uranium in groundwater at SRS is highly dependent upon the local chemical state of the groundwater. Thus, uranium in the groundwater may move at the same rate as the groundwater or be retarded and move slower by orders of magnitude than the ambient groundwater.

A comprehensive assessment of hydrological conditions and the status of groundwater contamination has been completed for each SRS environmental site that contains radioactivity. These assessments are contained in a series of environmental information documents that were completed from 1985 to 1986. A brief summary of the data contained in these documents plus additiona! relevant information from the annual SRS Environmental Reports are provided in this section. The reference environmental documents contain additional information.

The sources of groundwater uranium, measurements of uranium in groundwater, transport of uranium in groundwater, modeling efforts, and the ultimate fate of the uranium will be discussed in the following sections on each uranium source in groundwater at SRS. Unresolved issues will also be addressed when relevant.

\section{The SRS Groundwater System}

The Coastal Plain groundwater system 2 SRS is very complex. The geology at the site indicates a past environment where many interbedded clay, silt, and sand layers were deposited in an intricate three-dimensional flow system. The groundwater system can be divided into six main units, which are composed of several separate geologic layers (Figure 3-24).

At the base of the groundwater system is a dense clay, which retards the movement of water (an aquitard). Overlying this layer is the region of loosely packed sediments laid down during the Cretaceous period (formerly referred to as the Tuscaloosa formation). The Cretaceous-age unit is an excellent source of water and can sustain yields of $63 \mathrm{~L} / \mathrm{sec}$.

A 30-40 meter thick unit that is composed of thick silty clay material that forms a leaky aquitard unit above the Cretaceous aquifer. Overlying this aquitard is a Tertiaryage aquifer. This unit is on average $30-\mathrm{m}$ thick, consisting predominantly of fine-to-medium and medium-to-coarse, well-sorted sands. The Tertiary-age aquifer is not nearly as prolific as the Cretaceous aquifer below it, but it can sustain yields up to $6.3 \mathrm{~L} / \mathrm{sec}$. 


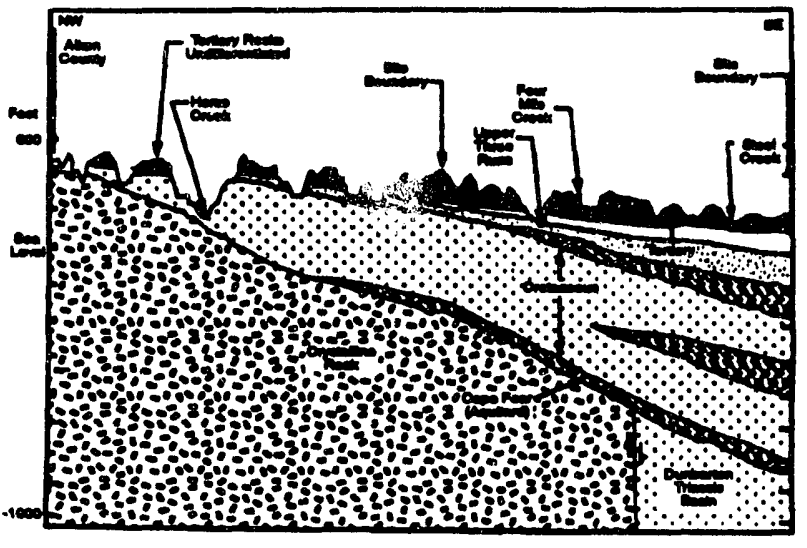

Figure 3-24. Geological Cross Section showing the Main Aquifers

Overlying the Tertiary aquifer is a depositional layer which acts as a leaky aquitard unit. This unit is often referred to as the "green clay", a local designation in early documents because of the color of the glauconite interbedded in this layer. Overlying this unit is the water table unit, which extends to the surface. The water table unit is not an aquifer by strict definition because of its low water-producing capabilities. Several wells in the water table at SRS cannot produce $0.06 \mathrm{~L} / \mathrm{s}$ for a substantial period of time. Nevertheless, it is a distinct and important hydrologic unit because any aquifer contamination entering at the surface must flow through the water table unit before entering other groundwater units or discharging to surface waters. The thickness of the water table varies greatly across the site due to the changing topography. The thickness can be as low as zero where soil has been eroded away by a stream or as deep as $60 \mathrm{~m}$.

In some areas it is necessary to modify the units defined above because of local features. For example, to effectively describe the groundwater system in the northern part of SRS, it is necessary to divide the water table unit into three units consisting of an aquitard (referred to locally as the "tan clay") between two units with groundwater characteristics like the single water table unit. At K-, L, and P-Reactor Areas, in the southern portion of the site, evidence from core descriptions and geophysical logs indicates that the tan clay is very sporadic and thin in these areas and is, therefore, not a consistent unit.

\section{F-Area Seepage Basins}

The F-Area seepage basins are located in the central portion of SRS, west of Road C and opposite Road E (Figure 3-25) approximately $8 \mathrm{~km}$ from the nearest site boundary. The basins are at an elevation of about $85 \mathrm{~m}$ and approximately $610 \mathrm{~m}$ northwest of Four Mile Creek and $1830 \mathrm{~m}$ southwest of Upper Three Runs Creek. The bottom surface of the three F-Area basins covers approximately $22,000 \mathrm{~m}^{2}$. The three

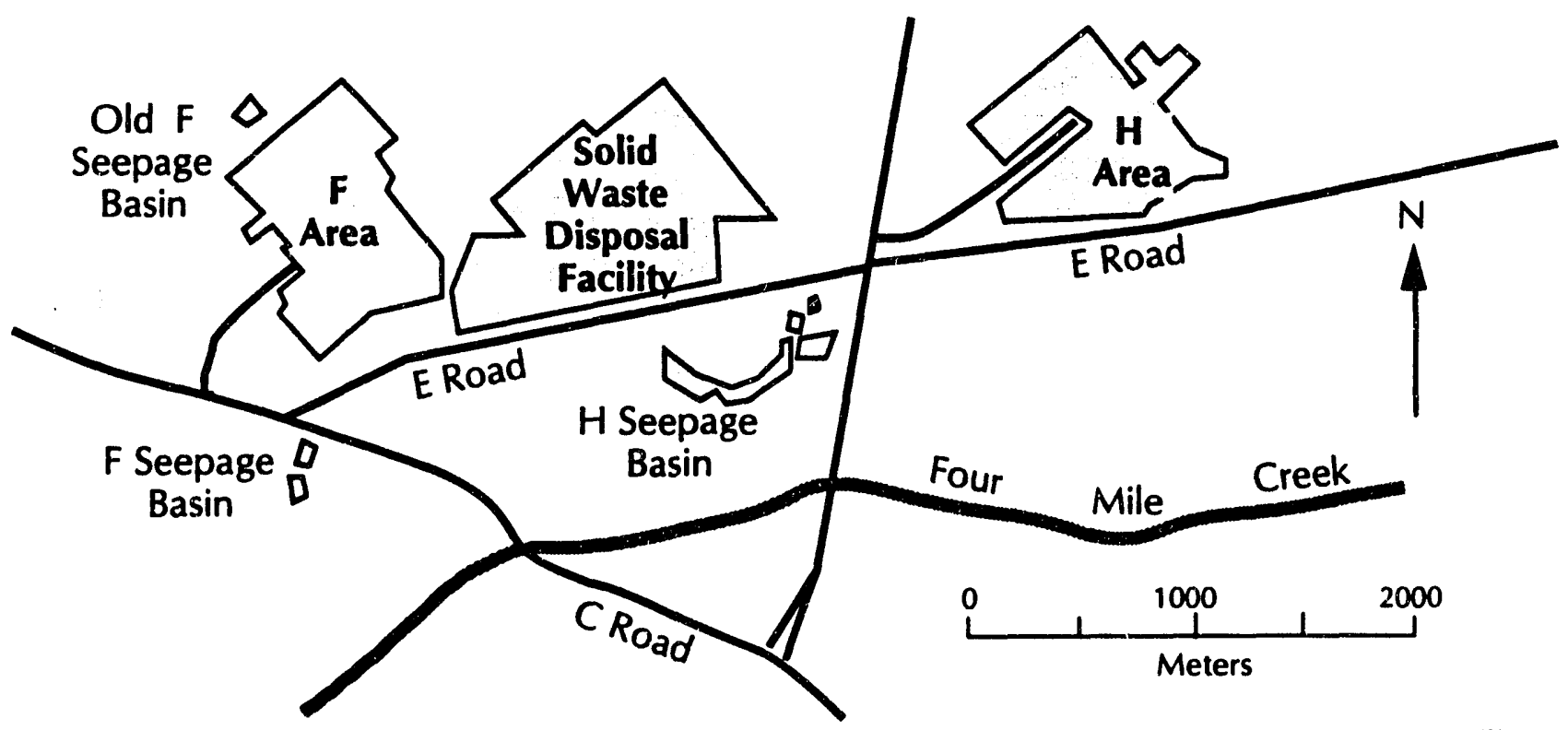

Figure 3-25. Location of F- and H-Area Seepage Basins on the High Ground Between Upper Three Runs and Four Mile Creek 


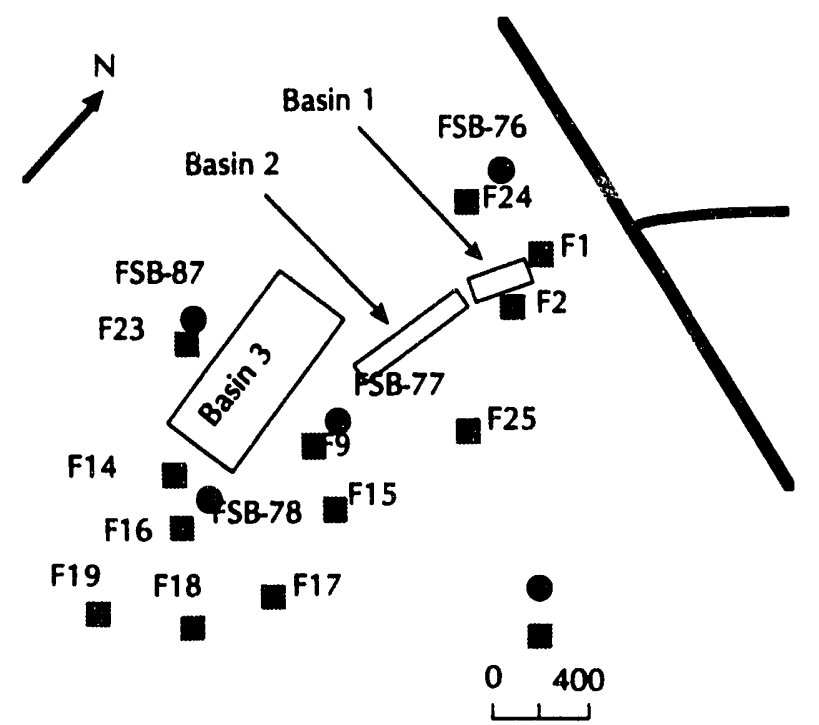

FSB-79

Figure 3-26. Placement of Wells Around the F-Area Seepage Basins

F-Area basins had a combined capacity of about $109,000 \mathrm{~m}^{3}$ at overflow conditions. From 1955 to 1988, the F-Area seepage basins routinely received wastewater containing uranium from the F-Area separations facilities. The wastewaters entered the basins through a single underground pipeline into Basin 1 and then flowed from Basin 1 to Basin 2 and Basin 3 through underground pipelines (Figure 3-26). Most of the groundwater flow from the F-Area basins to Four Mile Creek is from Basin 3. The purpose of these basins was to delay the release of radionuclides to surface streams by using the unsaturated soil column and groundwater pathways. The basins were taken out of service in 1988 and have since been stabilized and covered with a low permeability cap to reduce infiltration of contaminants to the groundwater.

Groundwater flow at the basins is generally downward through the unsaturated zone to the water table. When this vertical flow from the seepage basin reaches the water table, the flow path is generally downward and horizontal toward Four Mile Creek. The average gradient between Basin 3 and Four Mile Creek is approximately 0.014. The uranium isotopes ${ }^{234} \mathrm{U},{ }^{233} \mathrm{U}$, and ${ }^{238} \mathrm{U}$ are routinely detected above background in water table monitoring wells adjacent to and downgradient from the F-Area Seepage Basins. Concentrations at some of these wells exceed the proposed drinking water standard by an order of magnitude. Recently, ${ }^{234} \mathrm{U}$, ${ }^{235} U$, and ${ }^{238} U$ have been detected at the outcrop along Four Mile Creek, at least $100 \mathrm{~m}$ downgradient from the basins. (Haselow et al., 1990)

\section{H-Area Seepage Basins}

The H-Area seepage basins are located in the center of SRS, southwest of Road E and north of Road 4 (Figure 3-27), approximately $10 \mathrm{~km}$ from the nearest plant boundary. Basin 3 has been inactive since 1962. Use of basins 1,2, and 4 was discontinued in December 1988, and all four basins have now been stabilized and capped. The four basins had a combined floor area of approximately $42,700 \mathrm{~m}^{2}$. The three basins that operated until 1988 had a combined capacity of approximately $140,000 \mathrm{~m}^{3}$ at overflow conditions. Wastewater to these basins entered through a single underground pipeline into Basin 1, then traveled from Basin 1 through four pipelines into Basin 2 and then to Basin 4. The purpose of these basins was to use the soil column and groundwater pathways to delay the release of radioactivity to surface streams.

Since 1955, the H-Area seepage basins have received wastewater containing cooling water from the tritium facilities, other $\mathrm{H}$-Area operations. retention basin transfers, the receiving basins for offsite fuel, and two tank farm waste

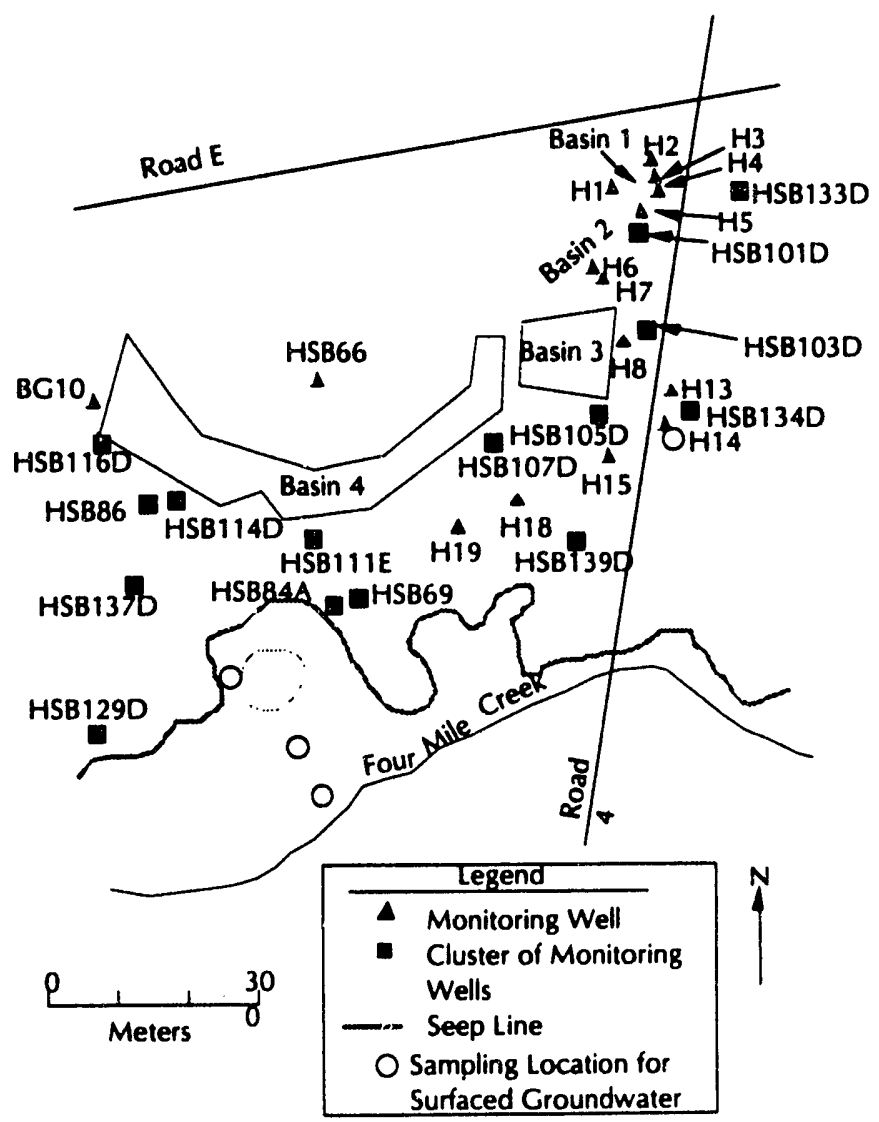

Figure 3-27. Location of H-Area Seepage Basin Wells 
evaporators. The average daily flow into the basins for 1985 was $577 \mathrm{~m}^{3} /$ day. Radioactive releases to the seepage basins, as monitored by the Environmental Monitoring Section, were greater than $99 \%$ tritium, but also contained other radionuclides including ${ }^{234} \mathrm{U},{ }^{235} \mathrm{U}$, and ${ }^{230} \mathrm{U}$.

Flow out of tite seepage basins is approximately vertically downward through the unsaturated zone to the water table. The horizontal component of groundwater flow from beneath the H-Area seepage basins is toward Four Mile Creek. The average gradient between Basin 4 and Four Mile Creek ranges between 0.02 and 0.033 , but this gradient includes an increased gradient as the creek is approached. The water table at H-Area seepage basins is 4.6 to $7.6 \mathrm{~m}$ below ground level and crops out at Four Mile Creek from 120 to $430 \mathrm{~m}$ south of the basins. Once in the water table, uranium moves horizontally to Four Mile Creek and vertically into lower aquifers where it moves to Four Mile Creek and Upper Three Runs Creek and ultimately to the Savannah River. Isotopes of uranium $\left({ }^{23} U,{ }^{235} U\right.$ and $\left.{ }^{208} U\right)$ are routinely monitored in water table monitoring wells near the H-Area basins at concentrations above proposed drinking water standards. They have also been detected above these standards at the Four Mile Creek seepline downgradient from the basins (Haselow et al., 1990).

\section{M-Area Settling Basin and Lost Lake}

The M-Area Settling Basin and Lost Lake are located in M Area (Figure 3-28). The location is in the northwestem section of SRS and is approximately $1,800 \mathrm{~m}$ from the nearest site boundary. The basin was closed and covered with a clay cap in 1990 . The bottom dimensions of the basin were approximately $85 \mathrm{~m} \times 70 \mathrm{~m}$ with a depth of about $5.2 \mathrm{~m}$. The total original liquid capacity of the basin was about $30,000 \mathrm{~m}^{3}$. Liquids were discharged into the basin through an underground sewer.

Lost Lake is a natural impression of approximately 10 to 25 acres, depending on water level. Prior to closure of the settling basin, Lost Lake was wet except during very low precipitation periods. Water levels in Lost Lake varied widely as a result of increases in process discharges and rainfall. Lost Lake has no outlet; therefore, all liquids that entered the area either seeped into the ground or evaporated.

The waste effluent generated from M-Area operations that was discharged to the basin can be characterized as electroplating waste from aluminum-forming and metalfinishing processes. The waste effluent contained hydroxide precipitates of aluminum, uranium, nickel, lead, and other metals. Depending on the operating schedule, the waste

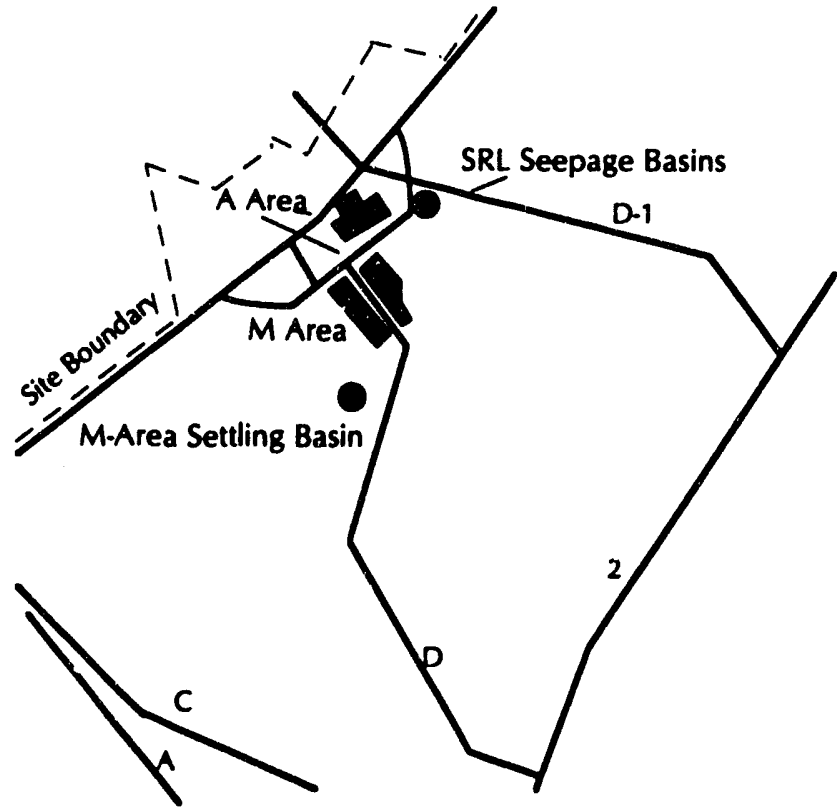

Figure 3-28. Location of M-Area Settling Basin and SRL Seepage Basins

effluent may have also contained acids (nitric, phosphoric, or sulfuric) or caustic (sodium hydroxide).

Estimates of total uranium discharge to the basin system are not available until after 1974, when flow instruments were installed. From 1974 through 1985, a total of $1.15 \mathrm{Ci}$ of uranium was released to the basin.

Several groundwater monitoring wells are located around the M-Area settling basin and Lost Lake. These wells are sampled quarterly and the water is analyzed for several constituents. The results of the quarterly analyses indicate that uranium is below the detection limit in the groundwater surrounding the basin and Lost Lake. However, there are detectable amounts of uranium in the soils that remain in the basin (Pickett et al., 1987).

\section{SRL Seepage Basins}

The Savannah River Laboratory (SRL) Seepage Basins are located in the northwestern section of the Savannah River Site in the 700 Area (Figure 3-28). The basins are about $1000 \mathrm{~m}$ from the nearest site boundary. Currently, the four basins are out of service. When in operation, the basins received low-level radioactive wastewater from laboratories located in Buildings 735-A and 773-A. A total of $130,000 \mathrm{~m}^{3}$ of wastewater was sent to the basins. Only wastewater with radioactivity less than $100 \mathrm{dpm} / \mathrm{mL}$ alpha and/or $50 \mathrm{dpm} / \mathrm{mL}$ beta-gamma was discharged to the 
basins. The uranium and plutonium content of the waste transferred to the basins during 1982 averaged $0.4 \mathrm{mCi}$ per month. Uranium and plutonium in the waste water were divided approximately as follows: ${ }^{236} \mathrm{U}(90 \%),{ }^{238} \mathrm{Pu}(5 \%)$, and ${ }^{20} \mathrm{Pu}(5 \%)$

The first two basins were placed into operation in 1954; Basin 3 and Basin 4 were added in 1958 and 1960, respectively. The four basins are connected sequentially by overflow channels; however, the final basin has no overflow. Any fluid losses from the SRL Seepage Basins were predominantly from seepage through the bottom of the basins. Wastewater seidom entered Basin 4 because seepage in Basins 1 through 3 was approximately equal to input volume.

Six groundwater monitoring wells (ASB 1 through 6) immediately adjacent to the basins were installed in 1981 . As part of the basin characterization program, three additional wells (ASB 7, ASB 8, and ASB 9) were installed at varying distances from the basin to determine the approximate groundwater gradients and flow directions. The results of quarterly analyses of groundwater near the SRL basins indicate that uranium are not above background concentrations. Analyses of soil at the basins indicate that a few soil samples have concentrations of ${ }^{235} \mathrm{U}$ above background (Fowler et al., 1987). The ${ }^{235} \mathrm{U}$ is not detectable in the groundwater because it is diluted or retarded significantly by the soil and has not reached the water table.

\section{CMX/TNX Seepage Basins}

There are three distinct disposal sites that have been identified at the TNX Area of the SRS. They are the TNX burying ground, the old TNX basins, and the new TNX basins. The disposal records indicate that the TNX burying ground and the old TNX basins received uranium in the form of uranyl nitrate, while the new TNX basins have never received radioactive material. Analyses of groundwater in the vicinity of the old TNX basins indicate that ${ }^{233234} \mathrm{U}$ are the only isotopes of uranium that are present in concentrations above $1 \mathrm{pCi} / \mathrm{L}$; at the groundwater monitoring wells near the TNX burying ground, both ${ }^{233} \mathrm{U},{ }^{233234} \mathrm{U}$ are above $1 \mathrm{pCi} / \mathrm{L}$ in at least one well (Cummins et al., 1990).

\section{Old TNX Seepage Basin}

The old TNX seepage basin is located in the southwestern section of the TNX facility (Figure 3-29). The basin was constructed in two sections: an inlet section and a large main section. Together these two sections encompassed approximately $952 \mathrm{~m}^{2}$ of TNX land area. The Savannah River, the

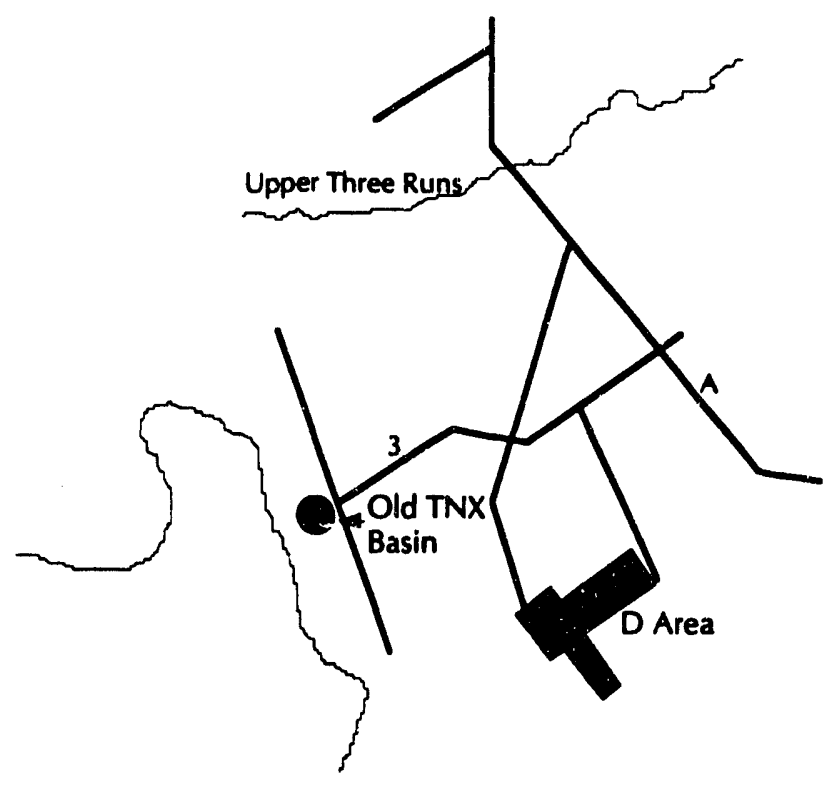

Figure 3-29. Location of the Old TNX Seepage Basin

nearest plant boundary to the basin, is $305 \mathrm{~m}$ to the west. Much of the land between the basin and the river is swampland.

The Old TNX Seepage Basin was built in 1958 and has received wastewater from pilot-scale tests conducted at TNX in support of plant Separations Areas, fuel and target manufacturing areas, and the Defense Waste Processing Facility (DWPF). In the spring of 1980, the wastewater flow to the basin was stopped, and the barin was taken out of service.

When in operation, process wastewater was delivered to the old TNX basin through an underground 20-cm-diameter vitrified pipeline. This pipeline entered the basin through the north wall of the settling section. A $13-\mathrm{cm}$ weir permitted effluent from the settling section to flow over into the main section. A similarly sized weir across the west wall of the main section directed the basin's overflow down into the nearby TNX swamp. During the 22-year loading history of the basin, overflow from the basin has resulted in the creation of an outfall delta about $30 \mathrm{~m}$ wide inside the swamp.

Depleted uranium was discharged to the old TNX basin, but no estimate of the amount is available.

\section{TNX Burying Ground}

The TNX burying ground, located within the TNX Area, was originally built to dispose of debris from an experimental evaporator explosion at TNX in 1953. As indicated in the 
discussion in Chapter 2, this evaporator contained approximately $590 \mathrm{~kg}$ of uranyl nitrate. From 1980 to 1984 , much of the waste material buried at TNX was excavated and sent to the SRS radioactive waste burial grounds for reburial. An estimated $27 \mathrm{~kg}$ of uranyl nitrate remains buried at TNX. The TNX Burying Ground consists of three sites known to contain waste and one site suspected of containing waste material.

The water table is approximately 12 to $15 \mathrm{~m}$ directly below the ground surface at the TNX facility at an elevation of approximately $30 \mathrm{~m}$ above MSL. This is approximately the same elevation as the Savannah River flood plain adjacent to the TNX facility. The water table depth to the northwest is approximately 6 to $9 \mathrm{~m}$, at an elevation of approximately $37 \mathrm{~m}$ above MSL.

Groundwater level measurements in water table wells in the area indicate a westerly direction of horizontal groundwater movement toward the Savannah River floodplain. The average hydraulic gradient in the water table is approximately 0.07 . Based on a recent aquifer test, the hydraulic conductivity is approximately $4 \mathrm{~m} /$ day. If one assumes the effective porosity is 0.20 , then the horizontal velocity of the groundwater in the water table is approximately $1.4 \mathrm{~m} / \mathrm{day}$.

A leaky aquitard separates the water table and the next deepest underlying water-bearing unit aquifer ILA at TNX. Based on available hydraulic head information for the water table and aquifer IIA, the gradient is vertically upward. Thus, contamination in the water table is prevented from migrating deeper and remains in the water table until it outcrops at the Savannah River.

\section{Other Locations}

The C-, R-, K-, L-, and P-Area reactor discharge basins all have received small amounts of uranium that were not captured during deionization. Also, the Ford Building received some uranium isotopes. The groundwater at the monitoring wells at these facilities is only monitored for gross alpha, and therefore, it is impossible to determine the uranium levels. 


\section{References}

Cummins, C. L., D. K. Martin, and J. L. Todd, 1990, Savannah River Site Environmental Report for 1989 (U). WSRC-IM-90-60 (Two Volumes). Westinghouse Savannah River Company, Aiken, SC.

Cummings, C. L., C. S. Hetrick, and D. K. Martin, 1991, Radioactive Releases at the Savannah River Site 1954-1989. WSRC-RP-91-684. Westinghouse Savannah River Company, Aiken, SC.

Dunaway, J. K. W., W. F. Johnson, L. E. Kingley, R. V. Simmons, and H. W. Bledsoe, 1987, Environmental Information Document, TNX Burying Ground. DPST-85-711. E. I. DuPont, Savannah River Laboratory, Aiken, SC.

Environmental Monitoring at the Savannah River Plant. Annual Report Series, 1953-1988, DPSPU-YR-30-2. E.I. DuPont, Savannah River Plant, Aiken, SC.

Environmental Monitoring at the Savannah River Plant for 1985, DPSPU-86-30-2. E.I. DuPont, Savannah River Plant, Aiken, SC.

Environmental Monitoring at the Savannah River Plant, Annual Report Series, 1989-1991, WSRC-IM-YR-4. Westinghouse Savannah River Company, Aiken, SC.

Federal Register Part II, Environmental Protection Agency, 1991, 40 CFR Parts 141 and 142, National Primary Drinking Water Regulations: Radionuclides: Proposed Rule, July 18, 1991.

Fay, M. D., and D. W. Hayes, 1983, Transport of Uranium and Other Elements in Southeastern U. S. River Systems.
DP-MS-83-96. E. I. DuPont, Savannah River Laboratory, Aiken, SC.

Fowler, B. F., B. B. Looney, R. V. Simmons, and H. W. Bledsoe, 1987, Environmental Information Document, Savannah River Laboratory Seepage Basins. DPST-85-688. E. I. DuPont, Savannah River Laboratory, Aiken, SC.

Haselow, J. S., M. Harris, B. B. Looney, N. V. Halverson and J. B. Gladden, 1990, Analysis of Soil and Water at the Four Mile Creek Seepline near the F\&H Areas of SRS (U), WSRC-RP-90-0591. Westinghouse Savannah River Company, Aiken, SC.

Hayes, D. W., 1984, Uranium Studies in the Tims Branch and Steed Pond System. DPST-84-847. E. I. DuPont, Savannah River Laboratory, Aiken, SC.

Pickett, J, B., 1990, Heavy Metal Contamination in Tims Branch Sediments. OPS-RMT-900200. Westinghouse Savannah River Company, Aiken, SC.

Pickett, J. B., W. P. Colven, and H. W. Bledsoe, 1987, Environmental Information Document. M-Area Settling Basin and Vicinity. DPST-85-703. E. I. DuPont, Savannah River Laboratory, Aiken, SC.

Starkle, W. M., M. Griffin, and K. E. Trapp, 1987. Biological and Chemical Assessment of $M$-Area Process Discharge to Tims Branch, June 1985-December 1986. Environmental and Chemical Sciences, Inc., Aiken, SC. 
Table 3-1. Specific Activity of Uranium as a Function of Isotopic Content (Page 1 of 2)

\begin{tabular}{|c|c|c|c|}
\hline $\begin{array}{l}{ }^{235} \mathrm{U} \\
\text { Percent }\end{array}$ & $\begin{array}{l}234 \mathrm{U} \\
\text { Percent }\end{array}$ & $\begin{array}{l}{ }^{238} \mathrm{U} \\
\text { Percent }\end{array}$ & $\begin{array}{c}\text { Specific Activity } \\
\text { grams/curie }\end{array}$ \\
\hline 0.00 & $0.00 \mathrm{e}+00$ & $1.000 \mathrm{e}+02$ & $2.975 e+06$ \\
\hline 0.01 & $7.50 a-05$ & $9.999 e+01$ & $2.932 e+06$ \\
\hline 0.02 & $1.500-04$ & $9.998 e+01$ & $2.891 e+06$ \\
\hline 0.03 & $2.25 a-04$ & $9.997 e+01$ & $2.851 e+06$ \\
\hline 0.04 & $3.000-04$ & $9.996 e+01$ & $2.812 e+06$ \\
\hline 0.05 & $3.75 e-04$ & $9.995 e+01$ & $2.774 e+06$ \\
\hline 0.06 & $4.500-04$ & $9.994 e+01$ & $2.737 e+06$ \\
\hline 0.07 & $5.25 a-04$ & $9.993 e+01$ & $2.701 e+06$ \\
\hline 0.08 & $6.000-04$ & $9.992 e+01$ & $2.666 e+06$ \\
\hline 0.09 & $6.750-04$ & $9.991 e+01$ & $2.632 e+06$ \\
\hline 0.10 & $7.500-04$ & $9.990 e+01$ & $2.599 e+06$ \\
\hline 0.11 & $8.25 e-04$ & $9.989 e+01$ & $2.566 e+06$ \\
\hline 0.12 & $9.000-04$ & $9.988 e+01$ & $2.534 e+06$ \\
\hline 0.13 & $9.75 a-04$ & $9.987 e+01$ & $2.504 e+06$ \\
\hline 0.14 & $1.05 e-03$ & $9.986 e+01$ & $2.473 e+36$ \\
\hline 0.15 & $1.13 a-03$ & $9.985 e+01$ & $2.444 e+06$ \\
\hline 0.16 & $1.200-03$ & $9.984 e+01$ & $2.415 e+06$ \\
\hline 0.17 & $1.28 a-03$ & $9.983 e+01$ & $2.387 e+06$ \\
\hline 0.18 & $1.35 e-03$ & $9.982 e+01$ & $2.360 e+06$ \\
\hline 0.19 & $1.43 e-03$ & $9.981 e+01$ & $2.333 e+06$ \\
\hline 0.20 & $1.500-03$ & $9.980 e+01$ & $2.307 e+06$ \\
\hline 0.21 & $1.58 e-03$ & $9.979 e+01$ & $2.281 e+06$ \\
\hline 0.22 & $1.65 e-03$ & $9.978 e+01$ & $2.256 e+06$ \\
\hline 0.23 & $1.73 a-03$ & $9.977 e+01$ & $2.232 e+06$ \\
\hline 0.24 & $1.800-03$ & $9.976 e+01$ & $2.208 e+06$ \\
\hline 0.25 & $1.880-03$ & $9.975 e+01$ & $2.184 e+06$ \\
\hline 0.26 & $1.950-03$ & $9.974 e+01$ & $2.161 e+06$ \\
\hline 0.27 & $2.030-03$ & $9.973 e+01$ & $2.139 e+06$ \\
\hline 0.28 & $2.100-03$ & 9.972ei J1 & $2.117 e+06$ \\
\hline 0.29 & $2.180-03$ & $9.971 e+01$ & $2.095 e+06$ \\
\hline 0.30 & $2.25 e-03$ & $9.970 e+01$ & $2.074 e+06$ \\
\hline 0.31 & $2.330-03$ & $9.969 e+01$ & $2.053 e+06$ \\
\hline 0.32 & $2.400-03$ & $9.968 e+01$ & $2.033 e+06$ \\
\hline 0.33 & $2.48 e-03$ & $9.967 e+01$ & $2.013 e+06$ \\
\hline 0.34 & $2.55 e-03$ & $9.966 e+01$ & $1.994 c+06$ \\
\hline 0.35 & $2.63 a-03$ & $9.965 e+01$ & $1.974 e+06$ \\
\hline 0.36 & $2.70 a-03$ & $9.964 e+01$ & $1.956 e+06$ \\
\hline 0.37 & $2.78 e-03$ & $9.963 e+01$ & $1.937 e+06$ \\
\hline 0.38 & $2.850-03$ & $9.962 e+01$ & $1.919 e+06$ \\
\hline 0.39 & $2.93 a-03$ & $9.961 e+01$ & $1.901 e+06$ \\
\hline 0.40 & $3.00 e-03$ & $9.960 e+01$ & $1.884 e+06$ \\
\hline 0.41 & $3.08 e-03$ & $9.959 e+01$ & $1.867 e+06$ \\
\hline 0.42 & $3.15 e-03$ & $9.958 e+01$ & $1.850 e+06$ \\
\hline 0.43 & $3.23 e-03$ & $9.957 e+01$ & $1.833 e+06$ \\
\hline 0.44 & $3.30 e-03$ & $9.956 e+01$ & $1.817 e+06$ \\
\hline 0.45 & $3.38 e-03$ & $9.955 e+01$ & $1.801 e+06$ \\
\hline 0.46 & $3.45 e-03$ & $9.954 e+01$ & $1.786 e+06$ \\
\hline 0.47 & $3.53 e-03$ & $9.953 e+01$ & $1.770 e+06$ \\
\hline 0.48 & $3.600-03$ & $9.952 e+01$ & $1.755 e+06$ \\
\hline 0.49 & $3.68 e-03$ & $9.951 e+01$ & $1.740 e+06$ \\
\hline 0.50 & $3.75 a-03$ & $9.950 e+01$ & $1.726 e+06$ \\
\hline
\end{tabular}


Table 3-1. Specific Activity of Uranium as a Function of Isotopic Content (Page 2 of 2)

\begin{tabular}{|c|c|c|c|}
\hline $\begin{array}{l}{ }^{235} \mathrm{U} \\
\text { Percent }\end{array}$ & $\begin{array}{l}{ }^{23} \mathrm{U} \\
\text { Percent }\end{array}$ & $\begin{array}{l}{ }^{238} \mathrm{U} \\
\text { Percent }\end{array}$ & $\begin{array}{l}\text { Specific Activity } \\
\text { grams/curie }\end{array}$ \\
\hline 0.51 & $3.830-03$ & $9.949 e+01$ & $1.711 e+06$ \\
\hline 0.52 & $3.90 e-03$ & $9.948 e+01$ & $1.697 e+06$ \\
\hline 0.53 & $3.980-03$ & $9.947 e+01$ & $1.683 e+06$ \\
\hline 0.54 & $4.05 e-03$ & $9.946 e+01$ & $1.670 e+06$ \\
\hline 0.55 & $4.13 e-03$ & $9.945 e+01$ & $1.656 e+06$ \\
\hline 0.56 & $4.200-03$ & $9.944 e+01$ & $1.643 e+06$ \\
\hline 0.57 & $4.28 e-03$ & $9.943 e+01$ & $1.630 e+06$ \\
\hline 0.58 & $4.350-03$ & $9.942 e+01$ & $1.617 e+06$ \\
\hline 0.59 & $4.43 e-03$ & $9.941 e+01$ & $1.604 e+06$ \\
\hline 0.60 & $4.500-03$ & $9.940 \mathrm{e}+01$ & $1.592 e+06$ \\
\hline 0.61 & $4.58 a-03$ & $9.939 e+01$ & $1.580 \mathrm{e}+06$ \\
\hline 0.62 & $4.650-03$ & $9.938 e+01$ & $1.568 e+06$ \\
\hline 0.63 & $4.73 a-03$ & $9.937 e+01$ & $1.556 e+06$ \\
\hline 0.64 & $4.800-03$ & $9.936 e+01$ & $1.544 \mathrm{e}+06$ \\
\hline 0.65 & $4.880-03$ & $9.935 e+01$ & $1.533 e+06$ \\
\hline 0.66 & $4.95 e-03$ & $9.934 \mathrm{e}+01$ & $1.521 \mathrm{e}+06$ \\
\hline 0.67 & $5.03 a-03$ & $9.932 e+01$ & $1.510 e+06$ \\
\hline 0.68 & $5.100-03$ & $9.931 e+01$ & $1.499 e+06$ \\
\hline 0.69 & $5.18 a-03$ & $9.930 e+01$ & $1.488 \mathrm{e}+06$ \\
\hline 0.70 & $5.25 e-03$ & $9.929 e+01$ & $1.477 e+06$ \\
\hline 0.71 & $5.33 e-03$ & $9.928 e+01$ & $1.467 e+06$ \\
\hline 0.72 & $5.40 e-03$ & $9.927 e+01$ & $1.457 e+06$ \\
\hline 0.73 & $5.48 e-03$ & $9.926 e+01$ & $1.446 e+06$ \\
\hline 0.74 & $5.550-03$ & $9.925 e+01$ & $1.436 e+06$ \\
\hline 0.75 & $5.63 e-03$ & $9.924 e+01$ & $1.426 e+06$ \\
\hline 0.76 & $5.700-03$ & $9.923 e+01$ & $1.416 e+06$ \\
\hline 0.77 & $5.78 e-03$ & $9.922 e+01$ & $1.407 e+06$ \\
\hline 0.78 & $5.85 e-03$ & $9.921 e+01$ & $1.397 e+06$ \\
\hline 0.79 & $5.93 a-03$ & $9.920 e+01$ & $1.388 e+06$ \\
\hline 0.80 & $6.00 e-03$ & $9.919 e+01$ & $1.378 e+06$ \\
\hline 0.81 & $6.08 e-03$ & $9.918 e+01$ & $1.369 e+06$ \\
\hline 0.82 & $6.15 e-03$ & $9.917 e+01$ & $1.360 e+06$ \\
\hline 0.83 & $6.23 e-03$ & $9.916 e+01$ & $1.351 e+06$ \\
\hline 0.84 & $6.30 e-03$ & $9.915 e+01$ & $1.342 e+06$ \\
\hline 0.85 & $6.38 e-03$ & $9.914 c+01$ & $1.334 e+06$ \\
\hline 0.86 & $6.45 e-03$ & $9.913 e+01$ & $1.325 e+06$ \\
\hline 0.87 & $6.53 e-03$ & $9.912 e+01$ & $1.317 e+06$ \\
\hline 0.88 & $6.60 c-03$ & $9.911 e+01$ & $1.308 e+06$ \\
\hline 0.89 & $6.68 e-03$ & $9.910 e+01$ & $1.300 e+06$ \\
\hline 0.90 & $6.75 e-03$ & $9.909 e+01$ & $1.292 e+06$ \\
\hline 0.91 & $6.83 e-03$ & $9.908 c+01$ & $1.284 e+06$ \\
\hline 0.92 & $6.90 \mathrm{e}-03$ & $9.907 e+01$ & $1.276 e+06$ \\
\hline 0.93 & $6.98 \mathrm{e}-03$ & $9.906 e+01$ & $1.268 e+06$ \\
\hline 0.94 & $7.05 e-03$ & $9.905 e+01$ & $1.260 e+06$ \\
\hline 0.95 & $7.13 a-03$ & $9.904 e+01$ & $1.252 e+06$ \\
\hline 0.96 & $7.20 e-03$ & $9.903 e+01$ & $1.245 e+06$ \\
\hline 0.97 & $7.28 \mathrm{e}-03$ & $9.902 e+01$ & $1.237 e+06$ \\
\hline 0.98 & $7.35 e-03$ & $9.901 e+01$ & $1.230 e+06$ \\
\hline 0.99 & $7.43 e-03$ & $9.900 e+01$ & $1.223 e+06$ \\
\hline 1.00 & $7.50 e-03$ & $9.899 e+01$ & $1.215 e+06$ \\
\hline
\end{tabular}


Table 3-2. Corrected Uranium Releases to Tims Branch

Year

1955

1956

1957

1958

1959

1960

1961

1962

1963

1964

1965

1966

1967

1968

1969

1970

1971

1971

1972

1973

1974

1975

1976

1977

1978

1979

1980

1981

1982

1983

1984

1985

1986

1987

1988

1989
Gross Alpha Measurement Ci to Tims Branch

0.0700

0.5200

0.1050

0.0360

0.0390

0.1100

0.1100

0.5300

1.9530

0.4960

0.9000

4.4300

6.4230

4.2140

1.2620

0.6820

0.3480

0.3480

0.3900

0.2190

0.3490

0.4410

0.3630

0.0844

0.0559

0.0640

0.1898

0.1710

0.0421

0.0173

0.0097

0.0014

0.0439

0.0055

0.0055

0.0004
U/Pu Measurement

Corrected Ci

0.0878

0.6521

0.1317

0.0451

0.0489

0.1379

0.1379

0.6646

2.4491

0.6220

1.1286

5.5552

8.0544

5.2844

1.5825

0.8552

0.4364

0.4364

0.4891

0.2746

0.4376

0.5530

0.4552

0.1058

0.0701

0.0803

0.2380

0.2144

0.0528

0.0217

0.0122

0.0017

0.0550

0.0069

0.0069

0.0005 
Table 3-3. Uranium Sediment Cores from Steed Pond*

$\begin{array}{lccc}\text { Reference } & \begin{array}{c}0-6 \text { Inches, } \\ \mu \mathrm{g} / \mathrm{g}\end{array} & \begin{array}{c}6-12 \text { Inches, } \\ \mu \mathrm{g} / \mathrm{g}\end{array} & \begin{array}{c}12-24 \text { Inches } \\ \mu \mathrm{g} / \mathrm{g}\end{array} \\ 1 & & & \\ 2 & 239 & 1.9 & 0.5 \\ 3 & 718 & 104.0 & 1.2 \\ 4 & 656 & 6.4 & 1.8 \\ 5 & 570 & 2.9 & 1.6 \\ 6 & 754 & 41.5 & 29.0 \\ 7 & 1113 & 1.7 & 0.9 \\ 8 & 684 & 12.0 & 0.3 \\ 9 & 770 & 318 & 36.5 \\ 10 & 2665 & 734 & 1.6 \\ 11 & 1853 & 6165 & 605 \\ 12 & 2211 & 3577 & 215 \\ 35 & 2082 & 8.5 & 1.8 \\ 36 & 1320 & & \\ 37 & 1960 & & 75 \\ \text { Avg } & 1310 & & \\ \text { Weighted Avg } & 1260 & 914 & \\ \text { (0-24 inches) } & & & \end{array}$

* From SRS Annual Environmental Monitoring Report, 1985 


\section{Chapter 4. Health Effects and Biological Fate of Uranium in Man}

Uranium: may be introduced into the body by inhalation, ingestion, or injection. For occupationally exposed individuals, inhalation is probably the most significant pathway ( $T a n n e n b a u m, 1951)$. In the general population, inhalation and ingestion are of primary concern.

In this Chapter, the health effects arising from the chemical and radiological properties of uranium are discussed. The distribution and retention of uranium in the body is also described. Additionally, the figures-of-merit used by various advisory committees and regulatory agencies to minimize, and in some cases quantify, risks from uranium exposure are presented. 


\section{General Considerations of Uranium Toxicity}

Since the mid-nineteenth century, it has been recognized that the injection of large doses of uranium into the body significantly damages the kidneys (Stannard, 1988). Such effects are a result of the chemical characteristics of uranium. For this reason, and because of its low specific activity, the chemical toxicity of ingested or injected uranium generally presents a greater risk to exposed individuals than radiological toxicity.

Uranium may also present a significant health risk when inhaled in large concentrations. Long-term inhalation of uranium dust has been implicated in the development of lung cancers. The principal population for which this effect has been observed has been ore miners. Miners who smoke cigarettes are at a proportionally higher risk, which may indicate a synergistic effect between ore dust, radiation, and cigarette smoking (Lundin et al., 1969, Doull et al., 1980).

In addition to the route of entry, a number of other factors may affect uranium toxicity. Such factors include the nature of the uranium compound, the history of previous exposure, and the biological response to exposure, which varies from person to person.

Age at exposure, however, does not appear to be a major consideration (Tannenbaum, 1951). Among the factors listed here, the nature of the uranium compound is perhaps most significant. 


\section{Uranium Intake Rate and Body Burden}

Since uranium is present naturally in soils and fertilizers, it may also be found in food and human tissues. The average intake of uranium from all dietary sources ranges from about 1-2 $\mu \mathrm{g} /$ day (Welford and Baird, 1967, ICRP, 1979, Singh et al., 1990). The intake of uranium from tap water is generally negligible in comparison (Eisenbud, 1987).
The uranium ccintent of the body is on the order of $90 \mu \mathrm{g}$, most of which is located in the skeletal system. Lesser amounts will be found in the kidneys and in fat and muscle tissue (Hamilton, 1972, ICRP, 1979). 


\section{Distribution and Retention in the Body}

From $60 \%$ to essentially $100 \%$ of the uranium deposited in the body by inhalation or ingestion is eliminated quite rapidly (ICRP, 1979, Doull et al., 1980). Of the fraction retained in the body, approximately $22 \%$ is transferred through body fluids to the bone. Another $24 \%$ is considered to be equally distributed in the kidneys and other soft tissues. The remaining $54 \%$ is not retained by the transfer compartment (body fluids) and is eliminated without further exposure of body tissues (ICRP, 1979). This process is illustrated in Figure 4-1.
As noted in the figure, each body organ is considered to have two compartments in which uranium may be depositedone that eliminates most of the uranium within weeks and one that may retain uranium for years. Long-term retention of uranium compounds (i.e., compounds with long biological half-lives) is likely for about $10 \%$ of the uranium deposited in bone and is essentially negligible for kidneys and other tissues.

(a) Material Translocated to the Gastrointestinal (GI) Tract Following Inhalation or Ingestion

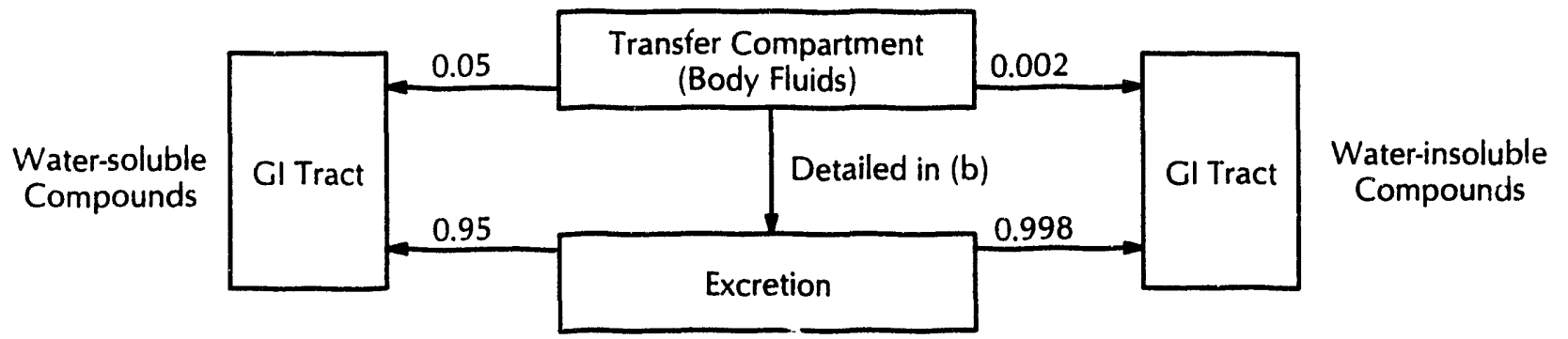

(b) Material Translocated to body Fluids

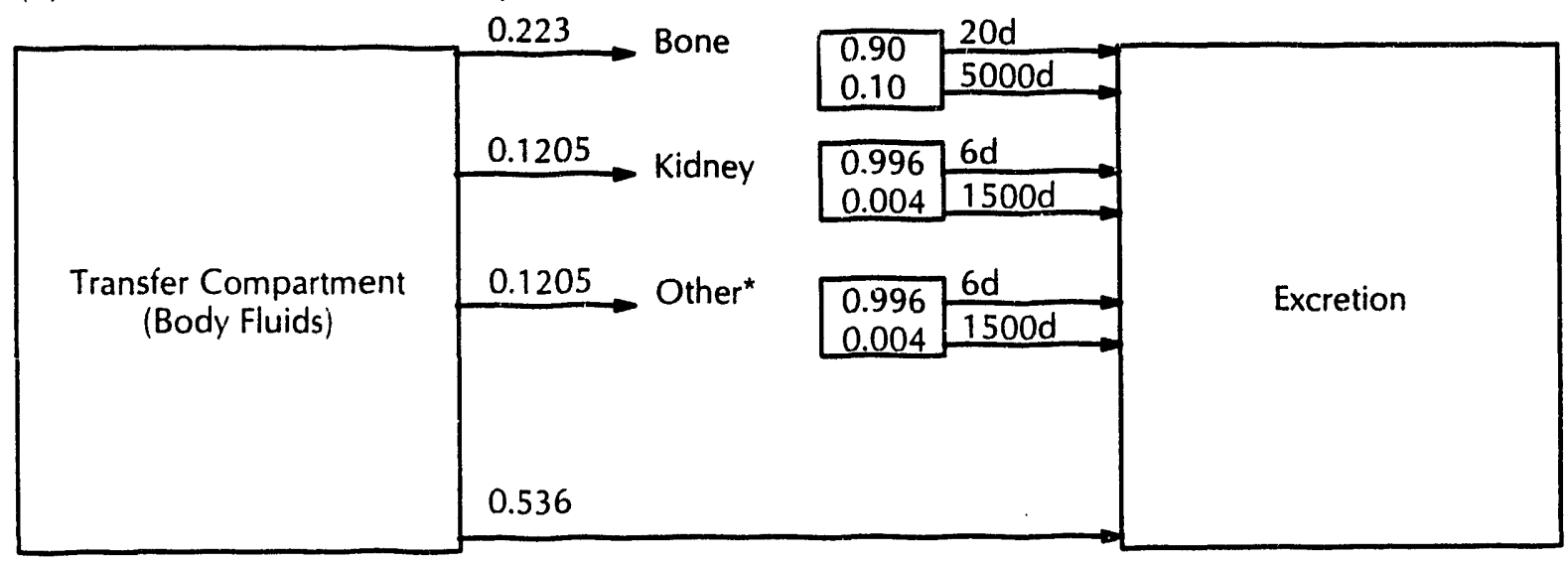

Other ${ }^{\star}=$ Assumed uniformly distributed in remaining soft tissue mass.

Figure 4-1. Biological Fate of Uranium in Man 


\section{Chemical Toxicity}

Relative to radiation dosimetry, the dosimetry of chemicals involves a more complex series of processes. Radiation-induced damage results from the deposition of energy in tissues via fairly well-known mechanisms. It is a unidirectional phenomenon which is therefore predictable to a certain degree. In contrast, chemically-induced damage arises from a myriad of pathways, essentially all of which also have the potential for action via feedback mechanisms. Chemicals may affect their own metabolism and excretion rates, and/or may be chemically altered to greater or lesser toxic forms.

\section{Mechanisms of Action}

Uranium in the human body is likely to be present in a chemical form referred to as a hexavalent uranyl ion, $U(V I)$. The key toxic feature of this form is its apparent ability to function as an enzyme inhibitor. Specifically, $U(V I)$ is believed to block the metabolism of glucose in the surface of a cell by inhibiting the enzyme hexokinase. Without access to this enzyme, glucose metabolism cannot occur (Gindler, 1973).

Another principal mechanism of uranium toxicity is the formation of complexing agents. Uranium, in relatively insoluble forms, may come into contact with $\mathrm{CO}_{2}$ prior to being eliminated. In some cases a U(VI)-bicarbonate complex is formed. This complex is often sufficiently soluble to facilitate the transfer of uranium from the blood stream to other tissues such as the skeleton and the kidneys (Gindler, 1973).

The uranyl-bicarbonate complex is responsible for the kidney damage induced by high uranium concentrations. As the proximal tubules of the kidneys resorb the bicarbonate and liberate the urar.vl ion, the tubular epithelium is damaged. This degeneration may result in death. However, if exposure is not severe, the epithelium will be regenerated and recovery occurs (Doull et al., 1980).

\section{Evaluating Chemically-Based Doses and Risks}

For chemical dosimetry, there is no single internationallyaccepted committee from which consensus relationships between concentration and dose, and between dose and risk are produced. The Environmental Protection Agency
(EPA) and other U.S. regulatory and advisory agencies have, however, provided some guidance. These guidelines were born out of the necessity of addressing the risk assessment needs of the toxic waste and environmental restoration projects for which they are responsible.

The EPA recognizes two broad categories of chemical toxins: carcinogens and noncarcinogens. For the purpose of conducting risk assessments, these two categories of hazards are treated in quite distinct fashions. The application of those methodologies to environmental exposure conditions is described below.

\section{Carcinogens}

An indicator of carcinogenic risk is the $10 \%$ Effective Dose (ED10). The ED10 represents the dose at which a 10 percent incremental carcinogenic response is observed (EPA, 1986). The effective dose is expressed in the units of $\mathrm{mg} / \mathrm{kg} /$ day and is principally a function of the potency factor assigned to the carcinogen. A potency factor is based on the upper $95 \%$ confidence limit on the slope of the dose-response curve and is specific to the route of intake.

\section{Noncarcinogens}

The analogous figure-of-merit for noncarcinogens is the Minimum Effective Dose (MED). Once an MED (a threshold for a given dose-response relationship) has been established, it is then possible to assign a value for the Chronic Acceptable Intake (AIC). For many chemicals an AIC is essentially equivalent to the so-called reference dose (RfD). RfDs are expressions of toxicant doses that are not likely to present appreciable risk of significant effects to human populations over a lifetime of exposure (EPA, 1986).

When evaluating noncarcinogens, the severity of the effect is also taken into account. Noncarcinogens are assigned rating constants, $\mathrm{RVes}$, which correspond to various levels of severity.

\section{Toxicity Constants}

For both carcinogens and noncarcinogens, toxicity constants are assigned to chemicals as indicators of potential risk. Such constants are used to establish figures-of-merit 
Table 4-1. Toxicity Data for Uranium

\begin{tabular}{|c|c|c|}
\hline & Uranium and & ompounds \\
\hline & $\begin{array}{l}\text { Minimum } \\
\text { Effective } \\
\text { Dose (MED), } \\
\text { mg/day }\end{array}$ & $\begin{array}{l}\text { Severity } \\
\text { Constant } \\
\left(R_{e}\right)\end{array}$ \\
\hline Ingestion & 1.7 & 6 \\
\hline Inhalation & 1.7 & 6 \\
\hline $\begin{array}{l}\text { for toxicant } \\
\text { (sT). These } \\
\text { tions about } \\
\text { the case of a } \\
\text { water per } \\
\text { noncarcinog } \\
\text { x RVe) / M } \\
\text { units are } \mathrm{L} / \mathrm{n} \\
\text { values prov } \\
\text { carcinogens } \\
\text { lations coul } \\
\text { produce con }\end{array}$ & $\begin{array}{l}\mathrm{s} \text { in air (aT), wat } \\
\text { rived from stand } \\
\text { d body weight. } \\
\text { esent in drinking } \\
\text { body weight } \\
\text { lation is } w \mathrm{Tn}=( \\
\mathrm{e} \text {, in either case } \\
\text { he application o } \\
\text { nction between } \\
\text { rcinogens (n). } \\
\text { rmed for aT (ai }\end{array}$ & $\begin{array}{l}(\mathrm{wT}) \text {, and soil } \\
\text { rdized assump- } \\
\text { or example, in } \\
\text { ater, } w \mathrm{Tc}=2 \mathrm{~L} \\
\mathrm{ED} 10 \text { ). For } \\
\text { L water per day } \\
\text { the appropriate } \\
\text { suffixes to the T } \\
\text { alues based on } \\
\text { nalogous calcu- } \\
\text { and sT (soil) to } \\
\text { ectively. }\end{array}$ \\
\hline
\end{tabular}

\begin{tabular}{cll}
\multicolumn{3}{c}{ Toxicity Constants } \\
\hline & & \\
Air & Water & Soil \\
$(\mathrm{aTn})$ & $(\mathrm{wTn})$ & $(\mathrm{sTn})$ \\
$\mathrm{m}^{3} / \mathrm{kg}$ & $\mathrm{L} / \mathrm{mg}$ & $\mathrm{kg} / \mathrm{mg}$ \\
& & \\
N/A & 7.06 & 0.000353 \\
70.6 & N/A & N/A
\end{tabular}

(EPA 1986)

\section{Uranium as an Indicator of Chemical Toxicity}

In a case where uranium would be an appropriate indicator of toxin, it would be treated as primarily a noncarcinogen for purposes of an environmental health risk assessment. The applicable figures-of-merit assigned to uranium and its compounds by the EPA are shown in Table 4-1.

As shown in Table 4-1, uranium has been assigned an RVe of 6, placing it in the mid-range of the severity scale used by the EPA. RVes of 5 to 6 indicate reversible cellular changes. An RVe of 1 indicates no pathological changes; an RVe of 10 signals death, pronounced life-shortening, or teratogenic effects. 


\section{Radiological Toxicity}

For enriched uranium there is a point at which the potential risk associated with the radiation dose exceeds that associated with the chemical dose. The enrichment required to invoke this change has been estimated to range from $5 \%$ to $16 \%$ by weight of ${ }^{235} U$ (Stannard, 1988). At such a transition point, the primary tissue at risk changes from the kidney to the bone.

It is important to note, however, that SRS releases of uranium have been chiefly natural uranium or depleted that is, uranium which has a maximum ${ }^{235} U$ content of $0.7 \%$ by weight. Therefore, though both are minimal, the chemical hazards outweigh the radiological hazards of uranium released from SRS. The combination of the low specific activity of uranium and the magnitude of SRS uranium releases produces dose contributions that are insignificant. For example in 1989 , the ${ }^{235} \mathrm{U}$ and ${ }^{238} \mathrm{U}$ contribution to offsite population doses from SRS atmospheric and liquid releases were approximately $1.6 \%$ and $0.01 \%$, respectively (Cummins et al., 1990). When one accounts for the fact that SRS releases represent about $0.05 \%$ of the ionizing radiation dose received by members of the public, the overall contribution from SRS atmospheric and liquid uranium releases is notably less than $0.001 \%$.

\section{The Radiological Decay Process}

Uranium irradiates surrounding tissue by the emission of ionizing radiation. Ionizing radiations are atomic particles and parcels of electromagnetic radiation that are sufficiently energetic to remove electrons from the atoms they encounter. Ionizing radiation may be divided into two general categories, which reflect the manner in which energy is transferred to the irradiated material. Low-LET (linear energy transfer) radiation is sparsely ionizing radiation: $x$-rays, gamma rays, and beta particles. High-LET radiation is associated with densely ionizing radiation such as alpha particles, which deposit a relatively large amount of energy in a small volume of tissue. Alpha particles are helium nuclei ( 2 protons, 2 neutrons, and 0 orbiting electrons).

Radioactive isotopes of uranium decay ${ }^{\prime}$, the emission of alpha particies to form radioactive isotopes of thorium. The thorium isotopes are the first of many daughters produced by the decay of a ${ }^{235} \mathrm{U}$ or ${ }^{238} \mathrm{U}$ atom. The applicable transformations and their respective haif-lives are shown in the following equations:

$$
\begin{aligned}
& { }_{92}^{235} \mathrm{U} \stackrel{7.04 \times 10^{8} \mathrm{y}}{\longrightarrow}{ }_{90}^{231} \mathrm{Th}+{ }_{2}^{4} \mathrm{He}(4.37-4.58 \mathrm{MeV})+\gamma^{*} \\
& { }_{92}^{238} \mathrm{U} \stackrel{4.47 \times 10^{9} \mathrm{y}}{\longrightarrow}{ }_{90}^{234} \mathrm{Th}+{ }_{2}^{4} \mathrm{He}(4.15-4.20 \mathrm{MeV})
\end{aligned}
$$

*The ${ }^{235} \mathrm{U}$ decay process is also accompanied by the release of gamma rays $(\gamma)$ ranging in energy from 0.14 to $0.20 \mathrm{MeV}$. ( $\mathrm{MeV}$ is the abbreviation for one million electron volts, a unit used to express energy on an atomic scale. One $\mathrm{MeV}=$ $1.6 \times 10^{-13}$ joules.)

\section{Tissues at Risk from Radiation-Induced Damage}

Because uranium is quickly eliminated from most other body tissues, the skeletal system is the primary tissue at risk from exposure to uranium. This is true for all routes of entry. However, when inhalation is the entry route, the impact on the lungs should also be considered.

\section{Uranium in Bone}

The damage to bone tissue from the decay of uranium arises from the ability of the alpha particles to disrupt or alter cellular function. This is particularly important with respect to red bone marrow because it is the site of red blood cell production. The primary radiation effects that could potentially result from exposure to uranium are osteosarcomas (bone cancers) and leukemia.

Uranium that is deposited in bone tissues and retained there for considerable periods of time may exhibit some mobility. In other words, unanium may migrate from outer bone surfaces to interior regions of mineral bone, red bone marrow, and surface cells surrounding the red bone marrow. Such movement is an important consideration if the uranium has a long radiological half-life because it may result in long-term irradiation of these tissues. It is also conceivable that this "burial" of uranium in bone would place it in contact with tissues that are more susceptible to radiation-induced damage than the original site of deposition.

Uranium translocated to the spongy matrix of mineral bone (trabecular bone) presents a relatively low risk because trabecular bone is not a particularly radiosensitive tissue. In 
Table 4-2. Inhalation Classes for Uranium Compounds

Compounds

$$
\begin{aligned}
& \mathrm{UF}_{6}, \mathrm{UO}_{2} \mathrm{~F}_{2}, \mathrm{UO}_{2}\left(\mathrm{NO}_{3}\right)_{2} \\
& \mathrm{UO}_{3}, \mathrm{UF}_{4}, \mathrm{UCl}_{4} \\
& \mathrm{UO}_{2}, \mathrm{U}_{3} \mathrm{O}_{8}
\end{aligned}
$$

Inhalation Class

D
W
Y

(ICRP, 1979) fact, regions of mineral bone may act as absorbers of high-LET radiation and provide some degree of protection for more sensitive tissues.

The International Commission on Radiological Protection (ICRP) recommends treating ${ }^{23.5} \mathrm{U}$ and ${ }^{238} \mathrm{U}$ as if they are uniformly distributed within the volume of mineral bone at all times following their deposition in the skeleton (ICRP, 1979).

\section{Uranium in the Lungs}

Figure 4-1 traces the biological fate of uranium once it reaches the gastrointestinal tract. However, when inhalation is the entry route, the lungs are also at risk from radiation induced damage. The ICRP evaluates potential damage to the lungs based on the length of time required to clear one-half of the material from lung tissue. Three retention classes are recognized: $D$ (clearance half-time 0.5 days), $\mathrm{W}$ (clearance half-time 50 days), and $\mathrm{Y}$ (clearance half-time $\mathbf{5 0 0}$ days). A longer clearance time results in a longer exposure time and therefore a greater lung dose. The inhalation classes of common uranium compounds are shown in Table 4-2 (ICRP, 1979).

\section{Evaluating Radiation Doses and Risks}

Radiation doses are expressed in terms of rad (radiation absorbed dose). A dose of one rad is equal to the absorption of 100 ergs of energy per gram of absorbing material. Since one rad of absorbed dose from different types of radiation can have different biological effects in man, the unit of rem was developed. Rem doses, or more precisely, dose equivalents, are obtained by multiplying rad doses by a quality factor. The quality factor (QF) places doses from all types of ionizing radiation on a common scale of biological effect (carcinogenesis). The QF for low-LET radiations ( $\mathrm{x}$-rays, gamma rays, and beta particles) is one. The $\mathrm{QF}$ for high-LET radiations such as alpha particles is 20 . Therefore, a one-rad dose of gamma radiation would be reported as a one-rem dose equivalent while a one-rad dose of alpha radiation would be reported as a 20 -rem dose equivalent.

Doses received from occupational or environmental exposures are typically too smail to express conveniently on the rem scale. The unit specified for use by DOE when referencing an individual's dose is the mrem (millirem), which equals one one-thousandth of a rem.

It is sometimes useful to pool the doses received by individuals into a population or collective dose. The DOE-sanctioned unit for collective doses is the person-rem. For example, if each of 100 individuals receives a dose of one rem, the resultant population dose is 100 person-rem. This person-rem collective dose equivalent may then be used to relate the dose received to the risks of specific health effects within that population.

\section{Cancer Risk Estimates}

The most comprehensive estimates of cancer induction by exposure to ionizing radiation come from studies of the atomic bomb survivors at Hiroshima and Nagasaki. Less definitive studies include those of medical patients exposed to therapeutic and diagnostic radiation. Studies of laboratory animals have increased the understanding of dose-effect relationships. The International Commission on Radiological Protection (ICRP) has evaluated all of these studies and concluded that the best estimate of lifetime risk of fatal cancer for members of the general population is approximately 500 cases per 1,000,000 person-rem (ICRP, 1991). This is equivalent to one case yer 2000 person-rem. 


\section{Summary}

Uranium is a naturally occurring element that presents both chemical and radiological hazards when taken into the body. It is typically present in the environment and the human body in concentrations that are too low to be deemed significant heath risks.

Most of the knowledge of the health effects of uranium has been gained from studies with laboratory animals. The tissues at risk from uranium exposure are specific to the health effect under consideration. For chemically-induced damage, the kidneys are the target organ. From a radiological perspective, the skeletal system is primarily at risk. 


\section{References}

BEIR (Biological Effects of Ionizing Radiations), 1980. Health Effects of Exposure to Low Levels of lonizing Radiation BEIR III, Committee on the Biological Effects of Ionizing Radiations, National Research Council, National Academy Press: Washington, D.C.

BEIR (Biological Effects of Ionizing Radiations), 1990. Health Effects of Exposure to Low Levels of lonizing Radiation BEIR V, Committee on the Biological Effects of Ionizing Radiations, National Research Council, National Academy Press: Washington, D.C.

Cummins, C. L., D. K. Martin, and J. L. Todd, 1990. Savannah River Site Environmental Report for 1989. WSRC-IM-90-60, Westinghouse Savannah River Company, Savannah River Site, Aiken, SC.

Doull, A.J., C.D. Klassen, and M.O. Amdur, eds., 1980. Casarett and Doull's Toxicology, New York: Maxmillan Publishing Co.

Eisenbud, M., 1987. Environmental Radioactivity from Natural, Industrial, and Military Sources, 3rd edition, New York: Harcourt Brace Jovanovich.

EPA (U.S. Environmental Protection Agency), 1986. Superfund Public Health Evaluation Manual, EPA/540/1-86-060, Office of Emergency and Remedial Response, U.S. EPA, Washington, D.C.

EPA (U.S. Environmental Protection Agency), 1989. Risk Assessments Methodology, Environmental Impact Statement NESHAPs for Radionuclides, Background Document, Volume I, EPA/520/1-89-005, Office of Radiation Programs, U.S. EPA, Washington, D.C.
Gindler, J.E., 1973. Physical and Chemical Properties of Uranium, pp. 69-164 in Handbook of Experimental Pharmacology Uranium - Plutonium - Transplutonium Elements, H.C. Hodge, J.N. Stannard, and J.B. Hursh, eds., New York: SpringerVerlag.

Hamilton, E.1., 1972. The Concentration of Uranium in Man and His Diet, Health Phys. 22:149-153.

ICRP (International Commission on Radiological Protection), 1979. Limits for Intakes of Radionuclides by Workers, ICRP Publication 30, Part 1, Annals of the ICRP.

ICRP, 1991, Risks Associated with Ionizing Radiations, Vol. 22, No. 1, Annals of the ICRP.

Lundin, F.E., Jr., J.W. Lloyd, E.M. Smith, V.E. Archer, and D.A. Holaday, 1969. Mortality of Uranium Miners in Relation to Radiation Exposure, Hard-Rock Mining and Cigarette Smoking - 1950 through September 1967, Health Phys. 16:571-578.

Singh, N., D.P. Burleigh, H.M. Ruth, and M.E. Wrenn, 1990. Daily U Intake in Utah Residents from Food and Drinking Water, Health Phys. 59(3):333-337.

Stannard, J.N., 1988. Radioactivity and Health - $A$ History, DOE/RL/1830-T59, Pacific Northwest Laboratory, Richland, WA.

Tannenbaum, A., 1951. Toxicology of Uranium, New York: McGraw-Hill.

Welford, G.A., and R. Baird, 1967. Uranium Levels in Human Diets and Biological Materials, Health Phys. 13:1321-1324. 


\section{Chapter 5. Impacts of SRS Uranium Releases on the Offsite Population}

This Chapter describes the health impacts associated with exposure to SRS-released uranium. The methodology used to produce dose estimates is presented. The results of a dose assessment for uranium releases during the 1955-1989 period are discussed. 


\section{Models of Uranium Transport and Dose}

With the exception of tritium, most of the radioactive materials currently released from SRS have such low concentrations in the offsite environment that they are not detectable by conventional monitoring techniques. Therefore, the impact of SRS on offsite individuals and populations are calculated with mathematical models. These models use known transport mechanisms for atmospheric and liquid releases, and known major pathways of exposure to man. Modeled atmospheric and aqueous dispersion characteristics of the site are periodically verified using environmental tritium measurements (tritium is released during normal SRS operations).

The first models used at SRS for calculating offsite doses were developed by the Savannah River Laboratory (SRL) (Cooper, 1975). These models, MREM (atmospheric releases) and RIVDOSE (liquid releases), were first used in 1972. In 1982, MREM and RIVDOSE were replaced with more technologically advanced models, which remain in use.

SRS annual offsite doses are currently calculated with the transport and dose models developed for the commercial nuclear industry (NRC, 1977a, NRC, 1977b). The models are implemented at SRS in the following computer programs:

atmospheric releases

- MAXIGASP: calculates dose to offsite individual under "maximum" or "average" exposure conditions

- POPGASP: calculates offsite population doses

liquid releases

- LADTAP II: calculates offsite individual doses under maximum or average exposure conditions and calculates doses to offsite populations

MAXIGASP and POPGASP are SRL-modified versions of the Nuclear Regulatory Commission (NRC) programs XOQDOQ (Sagendorf et al., 1982) and GASPAR (Eckerman et al., 1980). The modifications were made to meet the requirements for input of physical and biological data that are specific to SRS. The basic calculations in the XOQDOQ and GASPAR programs have not been modified. LADTAP
II (Simpson and McGill, 1980) is an essentially unaltered version of the NRC code of the same name.

\section{Modeling Atmospheric Dispersion of Radioactive Releases}

The routine atmospheric transport of radioactive materials from SRS is evaluated on the basis of meteorological conditions measured at seven onsite and one offsite meteorological towers. The towers relay wind speed, direction, and atmospheric stability information at five-second intervals to the SRL via the WIND (weather information and display) system. Currently, a data base of this information in the form of 60-min averages for 1982-1986 is accessed by the transport code to determine site-specific atmospheric dispersion characteristics.

The dispersion of an atmospheric release from SRS is modeled using $X O Q D O Q$, which computes concentrations in the plume as a function of downwind distance and compass sector. At the user's option, the plume can be depleted due to dry deposition or radioactive decay. Also, plume concentrations can be reduced by taking into account the upward displacement of the plume resulting from thermal buoyancy or momentum effects. This option is not used at SRS; that is, no credit is taken for plume rise.

The plume concentration information generated by XOQDOQ is then used by the dose modeling program GASPAR to estimate doses to offsite individuals and populations. GASPAR estimates doses from a number of pathways that are simplified in Figure 5-1.

The doses estimated by GASPAR are reported on a pathway-specific basis as follows:

- plume - external dose from material suspended in the atmosptiere

- ground - external dose from material deposited on the ground

- inhalation - internal dose from inhalation of contaminated material

- vegetation - internal dose from consumption of contaminated crops 


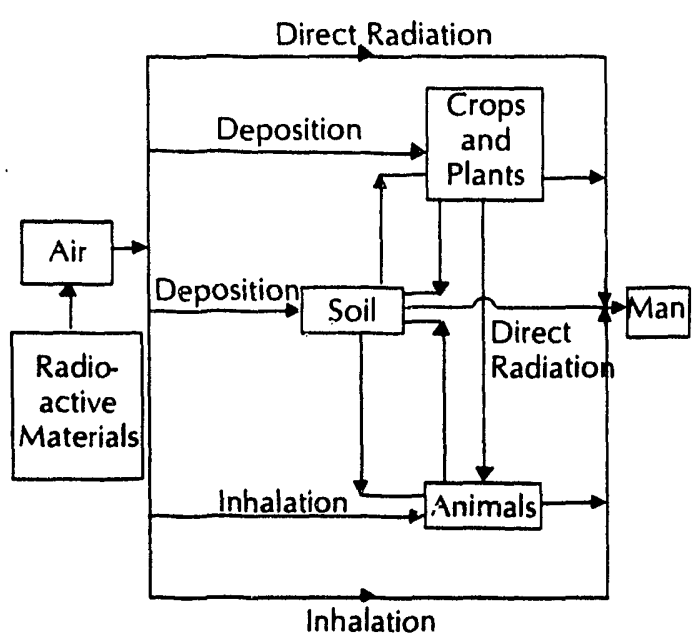

Figure 5-1. Simplified Pathways Between Radioactive Materials Released to the Atmosphere and Man

- milk - internal dose from consumption of milk produced in a contaminated area

- meat - internal dose from consumption of meat produced in a contaminated area

\section{MAXIGASP}

The calculations required by XOQDOQ and GASPAR to estimate maximum and average individual doses are performed at SRS using the computer program MAXIGASP. MAXIGASP calculates annual average groundlevel air concentrations and 50-year committed doses at a number of points along the site boundary in each of 16 $22.5^{\circ}$ compass sectors.

The main outputs from the program are the maximum dose equivalents to an individual along the SRS perimeter. The maximum-exposed individual is assumed to reside continuously at the location of highest exposure and to have living and eating habits that maximize the dose. These assumptions provide a ceiling on doses from atmospheric releases as no such individual is believed to exist.

The parameters used to calculate doses with MAXIGASP are presented in Table 5-1.

\section{POPGASP}

The calculations required by XOQDOQ and GASPAR to estimate population doses from atmospheric releases are performed at SRS using POPGASP, which calculates annual average groundlevel air concentrations and annual doses for each of 160 regions ( 16 wind direction sectors at 10 distances per sector) within an 80 -kilometer radius of the release location.

In addition to compass-sector specific meteorological information, POPGASP uses sector-specific data on population distribution and composition. Comparable data on milk, meat, and vegetable production and consumption are also used in the code. These data bases are quite extensive and are available for review in the SRS Environmental Reports published annually. With respect to the human parameters used in POPGASP, the key values are shown in Table 5-1.

\section{Modeling Doses from Liquid Releases}

The consequences of liquid releases from SRS are modeled using LADTAP II (liquid annual doses to all persons). The potential pathways of exposure from liquid releases to the environment are shown in Figure 5-2. The pathway-specific doses calculated by LADTAP are grouped into the following five categories:

- potable drinking water - internal dose from consumption of drinking water of Savannah River crigin

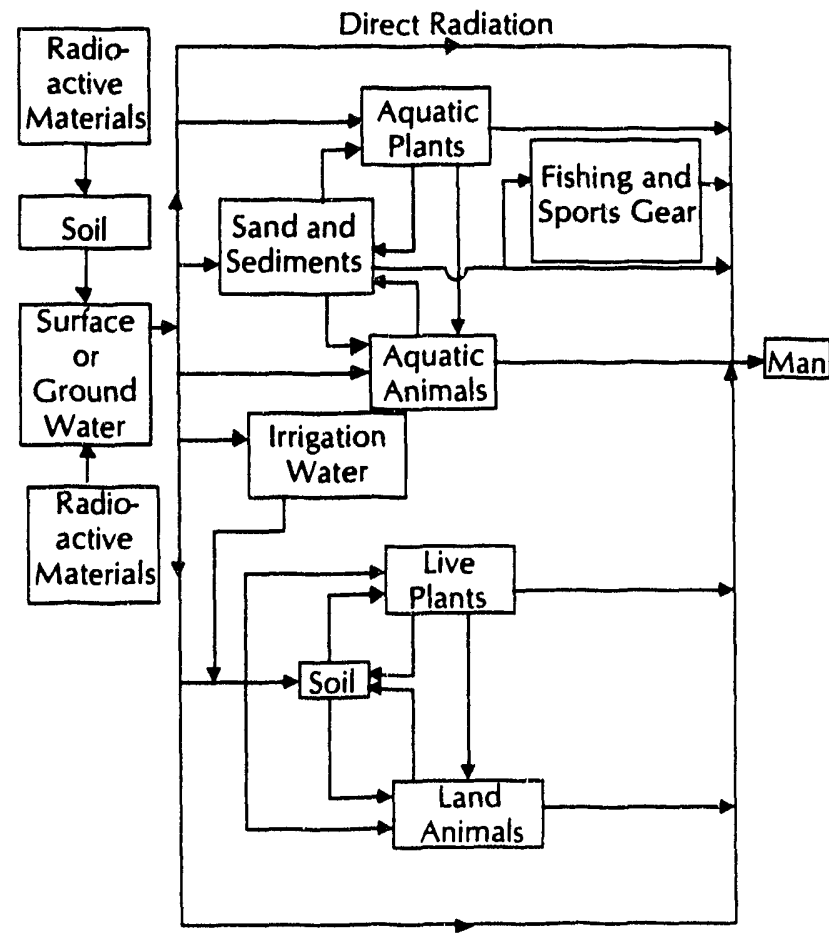

Figure 5-2. Simplified Pathways Between Radioactive Materials Released to Ground or Surface Waters and Man 
Table 5-1. Site- and Age-Specific Parameters for Atmospheric Releases

\section{Demographic Data}

\begin{tabular}{|c|c|c|c|c|}
\hline \multirow[b]{2}{*}{ Population Group } & \multirow[b]{2}{*}{ Size } & \multicolumn{3}{|c|}{ Age Distribution, \% } \\
\hline & & Children & Teens & Adults \\
\hline \multirow[t]{2}{*}{$80-\mathrm{km}$ radius } & 555,100 & 18.6 & 11.1 & 70.3 \\
\hline & \multicolumn{4}{|c|}{ Maximum Individual (MAXIGASP) } \\
\hline Exposure Pathway & Infant & Child & Teen & Adult \\
\hline Inhalation $\left(\mathrm{m}^{3} / \mathrm{yr}\right)$ & 1400 & 3700 & 8000 & 8000 \\
\hline \multicolumn{5}{|l|}{ Ingestion } \\
\hline Cow's milk (L/yr) & 244 & 244 & 297. & 230 \\
\hline Meat $(\mathrm{kg} / \mathrm{yr})$ & 0 & 30 & 48 & 81 \\
\hline Leafy vegetables $(\mathrm{kg} / \mathrm{yr})$ & 0 & 17 & 28 & 433 \\
\hline $\begin{array}{l}\text { Fruits, grains, and other } \\
\text { vegetables }(\mathrm{kg} / \mathrm{yr})\end{array}$ & 0 & 276 & 334 & 276 \\
\hline $\begin{array}{l}\text { External exposure } \\
\text { Transmission factor for } \\
\text { shielding from buildings }\end{array}$ & 0.7 & 0.7 & 0.7 & 0.7 \\
\hline
\end{tabular}

\begin{tabular}{|c|c|c|c|c|}
\hline \multirow[b]{2}{*}{ Exposure Pathway } & \multicolumn{4}{|c|}{ General Population (POPGASP) } \\
\hline & Infant & Child & Teen & Adult \\
\hline Inhalation $\left(m^{3} / y r\right)$ & 1400 & 3700 & 8000 & 8000 \\
\hline \multicolumn{5}{|l|}{ Ingestion } \\
\hline Cow's milk (L/yr) & 186 & 186 & 218 & 120 \\
\hline Meat $(\mathrm{kg} / \mathrm{yr})$ & 0 & 17 & 27 & 43 \\
\hline Leafy vegetables $(\mathrm{kg} / \mathrm{yr})$ & 0 & 8.5 & 14 & 21 \\
\hline $\begin{array}{l}\text { Fruits, grains, and other } \\
\text { vegetables }(\mathrm{kg} / \mathrm{yr})\end{array}$ & 0 & 163 & 205 & 171 \\
\hline $\begin{array}{l}\text { External exposure } \\
\text { Transmission factor for } \\
\text { shielding from buildings }\end{array}$ & 0.5 & 0.5 & 0.5 & 0.5 \\
\hline
\end{tabular}

- sports fish and commercial fish - internal dose from consumption of fish of Savannah River origin

- salt water invertebrates - internal dose from consumption of shell fish of Savannah River origin

- recreation - external dose from recreational activities in and along the Savannah River (boating, swimming, and shoreline activities)

- irrigation - internal dose from foods produced by irrigation with Savannah River water (there are currently no known users of the river for this purpose)
LADTAP estimates individual and population doses at specific downstream locations. The only removal mechanism included in the transport model as it is used at SRS is radioactive decay. Since ${ }^{235} \mathrm{U}$ and ${ }^{238} \mathrm{U}$ are long-lived isotopes, this mechanism is not a significant consideration for uranium dose calculations.

The major assumption in the application of LADTAP to SRS releases is that liquid discharges undergo complete mixing in the Savannah River before reaching potentially 
exposed populations. The validity of this assumption is supported by repeated measurements indicating complete mixing occurs in the river between the SRS and the Highway 301 sampling stations (Davis, Martin, and Todd, 1989).

LADTAP II generates individual and populations doses for all of the exposure pathways identified previously. Though standardized input values are provided in LADTAP II, SRS calculations are performed with site-specific information to the extent that is available. Summary tables of principal input values used in the SRS version of LADTAP II are shown in Table 5-2. 
Table 5-2. Site- and Age-Specific Parameters for Liquid Releases (page 1 of 2)

\section{Maximum Individual Dose Assessments (LADTAP II)}

\section{Site Parameters}

Savannah River flow rate at Highway $301, \mathrm{ft}^{3} / \mathrm{s}$

10,500 or measured average

Transit time from SRS to Savannah River, hr

24

Shore width factor

0.2

\section{Human Parameters}

Water consumption (L/yr)

Fish consumption $(\mathrm{kg} / \mathrm{yr})$

Shell fish consumption $(\mathrm{kg} / \mathrm{yr})$

Recreation (person-hr/yr)

Swimming

Boating

\begin{tabular}{cc}
\multicolumn{2}{c}{ Maximum Individ } \\
Infant & Child \\
$260(330)^{\mathrm{a}}$ & $260(510)^{\mathrm{a}}$ \\
0 & 6.0 \\
0 & 2.7 \\
0 & 27 \\
0 & 10 \\
0 & 25
\end{tabular}

Teen

Adult

"The values in parentheses are EPA parameters mandated for use when calculating maximum individual doses to Beaufort-Jasper and Port Wentworth water users.

\section{Population Dose Assessments (LADTAP II)}

\section{Site Parameters}

Savannah River flow rate at Highway $301, \mathrm{ft}^{3} / \mathrm{s}$

Transit time from SRS to Savannah River, hr

10,500 or measured average

Transit time from SRS to water treatment plant, $\mathrm{hr}$

24

Retention time in water treatment systen, $\mathrm{hr}$

Shore width factor

$\begin{array}{cc}260(510)^{\mathrm{a}} & 370(730)^{\mathrm{a}} \\ 14.0 & 19 \\ 6.1 & 8 \\ 128 & 23 \\ 50 & 8.9 \\ 117 & 21\end{array}$

River dilution in estuary

72

24

0.2

Aquatic food harvest $(\mathrm{kg} / \mathrm{yr})$

Sport fish

Commercial fish

Salt water invertebrates

\begin{tabular}{|c|c|c|c|c|}
\hline \multirow[b]{2}{*}{ Population Group } & \multirow[b]{2}{*}{$\underline{\text { Size }}$} & \multicolumn{3}{|c|}{ Age Distribution, \% } \\
\hline & & Child & Teen & Adult \\
\hline $80-\mathrm{Km}$ radius & 555,100 & 18.6 & 11.1 & 70.3 \\
\hline Beaufort-Jasper water users & 50,000 & 21.0 & 10.0 & 69.0 \\
\hline Port Wentworth water users & 15,000 & 0.0 & 0.0 & 100.0 \\
\hline
\end{tabular}


Table 5-2. Site- and Age-Specific Parameters for Liquid Releases (page 2 of 2)

\begin{tabular}{|c|c|c|c|c|}
\hline \multirow[b]{2}{*}{ Human Parameters } & \multicolumn{3}{|c|}{ A verage Individual } & \multirow[b]{2}{*}{ Adult } \\
\hline & Infant & Child & Teen & \\
\hline Waster consumption (L/yr) & 260 & 260 & 260 & 370 \\
\hline Fish consumption (kg/yr) & 0 & 2.9 & 6.8 & 9.0 \\
\hline \multirow[t]{2}{*}{ Shell fish consumption ( $\mathrm{kg} / \mathrm{yr}$ ) } & 0 & 0.7 & 1.5 & 2.0 \\
\hline & & & \multicolumn{2}{|c|}{ 80-km Population } \\
\hline \multicolumn{5}{|l|}{ Recreation (person-hr/yr) } \\
\hline Shoreline activities & & & \multicolumn{2}{|c|}{108,400} \\
\hline Swimming & & & \multicolumn{2}{|c|}{8,465} \\
\hline Boating & & & \multicolumn{2}{|c|}{232,000} \\
\hline
\end{tabular}




\section{Verification of Models Using Monitoring Data}

\section{Atmospheric Releases}

The radionuclide concentrations predicted by XOQDOQ are routinely compared with measured values of tritium concentrations in air to evaluate the performance of the code. (Tritium is the only radionuclide released by SRS that can be routinely detected offsite using conventional monitoring techniques.) Figure 5-3 shows a comparison of calculated and measured tritium oxide concentrations in air at the site perimeter. Other comparisons of predicted and measured concentrations have been made (Marter, 1984) and have exhibited similar results. The available data suggest calculated concentrations of tritium in air are generally conservative estimates of actual offsite values.

\section{Liquid Releases}

Comparisons of LADTAP-predicted tritium concentrations with measured values are made for three downstream locations that are important in terms of dose calculations: (I) just below the SRS, (2) at the Beaufort-Jasper water treatment plant, and (3) at the Port Wentworth water treatment plant. These comparisons provide known dilution factors that enhance LADTAP's ability to predict the downstream concentration of other radionuclides. Derived flow rates used for dose assessments for the Beaufort-Jasper water users and the Port Wentworth water users were calculated from measured flow rates at the USGS flow station at the Highway 301 crossing and measured tritium concentrations at all three locations.

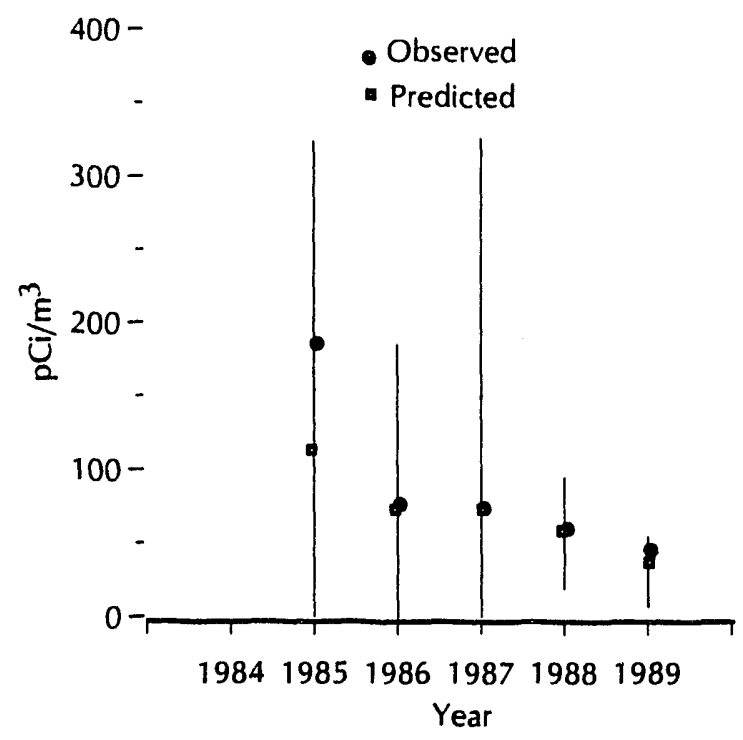

Figure 5-3. Predicted vs. Measured Tritium Oxide Concentrations in Air at the Site Perimeter

Occasionally, special studies of uranium concentrations in surface waters have been conducted. When sufficient data are available, these measured uranium values have been used to estimate the dose to the maximally exposed offsite individual (Cummins et al., 1990). At the downstream water treatment plants, though, uranium concentrations are below the detection limits of conventional monitoring systems and must be estimated as described previously. More detailed information on the nature and extent of studies of SRS stream systems may be found in the 1989 Annual Environmental Report (Cummins et al., 1990). 


\section{SRS Uranium Releases as a Chemical Hazard}

Concentrations of uranium in offsite air and surface water show no signs of SRS influence. Both environmental compartments exhibit uranium concentrations that cannot be distinguished from background levels in this region. One onsite stream system has been impacted by site operations. The processing of uranium in $\mathrm{M}$ Area has resulted in the release of significant quantities of uranium to Tims Branch, a small stream which discharges into Upper Three Runs Creek. The concentrations of uranium in Tims Branch water and sediment, and the rate of offsite transport, are discussed in Chapter 3 in this report.

\section{Surface Water Concentrations}

Figure 5-4 illustrates the uranium concentrations recently measured in SRS streams. Sample results from the Savannah River above (Shell Bluff) and below (Highway 301 ) the Site have been included to demonstrate the absence of a significant impact on the Savannah River. Concentration values ranged from 36 to 280 picograms per milliliter $(\mathrm{pg} / \mathrm{mL})$ with most values under $100 \mathrm{pg} / \mathrm{mL}$.

In Figure 5-4, the influence of Tims Branch uranium on Upper Three Runs Creek is clearly observable. Though these concentrations are considerably higher than the other stream systems, it should be noted that the highest Upper Three Runs values are approximately 200 times lower than the drinking water standard of $40,000 \mathrm{pg} / \mathrm{mL}$. Further, there are no known users of Savannah River water at this location or for dozens of kilometers further downstream.

\section{Air Concentrations}

Environmental airborne concentrations of uranium are typically too low to be detected by even the most technologi-

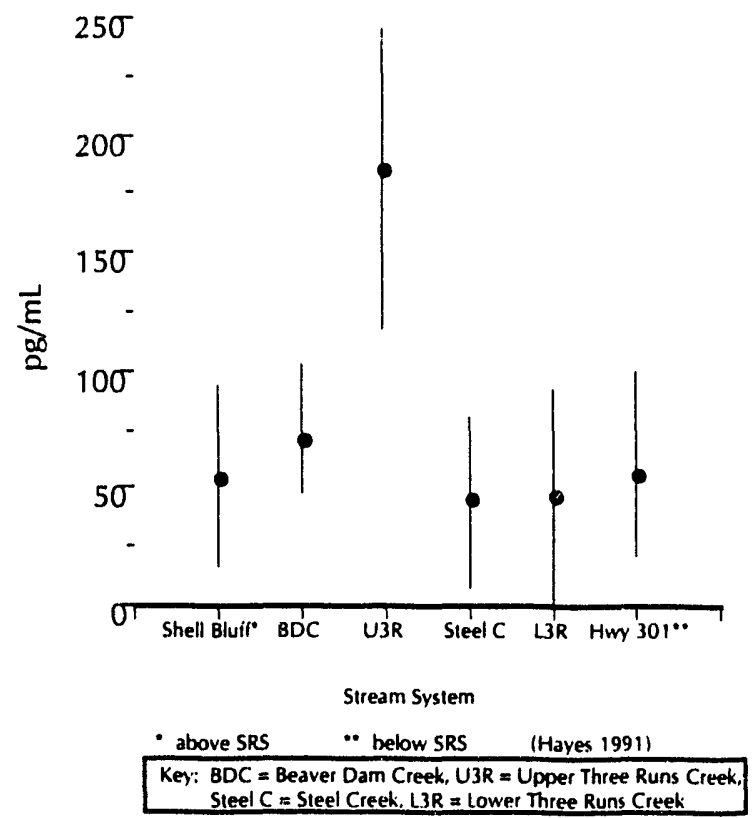

Figure 5-4. Uranium Concentrations in Regional Stream Systems Sampled Periodically from 8/89-6/90

cally advanced monitoring techniques. The computer code XOQDOQ therefore is routinely used to estimate annual average concentrations at the Site perimeter. For 1989, the annual average uranium concentration was estimated as $1.73 \times 10^{-12} \mathrm{mg} / \mathrm{m}^{3}$ (Cummins, et.al., 1990). This value is many orders of magnitude lower than the most restrictive exposure limits for uranium established by the three primary regulatory and advisory agencies in the United States on the basis of chemical toxicity. The exposure limits recognized by those agencies are included in Table 5-3. 
Table 5-3. Uranium Exposure Limits ${ }^{(a)}, \mathrm{mg} / \mathrm{m}^{3}$

Occupational Safety and Health Administration (OSHA)

Soluble Insoluble All U

PEL (8-hr TWA)

STEL. (any 15 -min period)

$0.05 \quad 0.2$

0.6

National Institute for Occupational Safety and Health (NIOSH)

Soluble Insoluble All U

REL (10-hr TWA)

$0.05 \quad 0.2$

STEL

$20 \quad 30$

IDLH

0.6

\section{American Conference of Governmental Industrial Hygienists (ACGIH)}

Soluble Insoluble All U

TLV (8-hr TWA)

STEL

0.2

0.6

(a) All values based on chemical toxicity of uranium.

PEL = Permissible Exposure Limit

TWA $=$ Time-Weighted Average

STEL $=$ Short-Term Exposure Limit

REL = Recommended Exposure Limit

IDLH = Immediately Dangerous to Life and Health

TLV $=$ Threshold Limit Value

(ACGIH, 1988, 1990; NIOSH, 1985) 


\section{SRS Uranium Releases as a Radiological Hazard}

Radiation dosimetry relates a unit intake of radioactivity to dose received. SRS dose codes use internal dose conversion factors to calculate dose equivalents. The dose factors prescribed for use by the DOE are typically expressed in units of rem/ $\mu \mathrm{Ci}$.

In this section, the 50-year committed effective dose equivalents (CEDEs) potentially received by individual members of the offsite population from SRS uranium releases are presented. For populations, the environmental dose commitment (EDC) has been estimated. EDCs are dose commitments which also take into account the long-term existence, and potential build-up, of radionuclides in various environmental compartments. At SRS, 100-year EDCs are used.

\section{DOE Internal Dose Factors}

To calculate the committed dose equivalent to specific body organs and the committed effective dose equivalent (CEDE) to an individual, SRS dose codes access dose factor libraries. The libraries contain radionuclide-specific and exposure pathway-specific factors which express the 50 -year committed dose that would result from the intake of a unit quantity of radioactivity. Internal dose factors for age groups other than adults are not currently available, but are under development.

The DOE dose factors are based on the ICRP models described in Chapter 4 of this report (ICRP, 1979). Doses to the offsite population from SRS uranium releases, as presented later in this Chapter, were calculated using the 1988 version of the DOE dose factors (DOE, 1988). The conversion facturis applicable to ${ }^{235} \mathrm{U}$ and ${ }^{238} \mathrm{U}$ dose calculations are listed in Table 5-4.

\section{Impact of SRS Uranium Releases on the Offsite Population}

The computer codes MAXIGASP, POPGASP, and LADTAP II have been used to calculate dose equivalents that have been theoretically received by segments of the offsite population from uranium. The results are shown in Tables 5-5 and 5-6 for doses attributable to atmospheric and liquid releases, respectively. Liquid releases have consistently exceeded atmospheric release levels, and this trend is reflected in the doses to the offsite populations reported in the tables.

Uranium releases to streams have been a mixture of natural uranium $\left(0.72 \%{ }^{235} \mathrm{U}, 1.52 \mathrm{Ci}\right)$ Slightly enriched uranium $\left(0.84 \%{ }^{235} \mathrm{U}, 7.78 \mathrm{Ci}\right)$ and depleted uranium $\left(0.2 \%{ }^{2.35} \mathrm{U}\right.$, $15.38 \mathrm{Ci}$ ). To be conservative, the doses were calculated and presented in Tables 5.5 and 5-6 as though all the releases were natural uranium.

\section{Doses from Atmospheric Releases}

As shown in Table 5-5, the largest effective dose equivalent received occurred in 1955, the year atmospheric uranium releases peaked. The dose to the "maximum" individual for 1955 was on the order of 0.2 mrem. ("Maximum" individuals are hypothetical persons who live at the SRS boundary at the location of highest exposure and subsist on diets of locally produced milk, meat, and vegetables. No

Table 5-4. DOE Dose Conversion Factors for Uranium, mrem/pCi

$\begin{array}{lcc} & \text { Inhalation } & \text { Ingestion } \\ \text { Lungs } & 1.0 \times 10^{\circ} & \mathrm{N} / \mathrm{A} \\ \text { Bone surfaces } & \mathrm{N} / \mathrm{A} & 3.7 \times 10^{-3} \\ \text { CEDE* } & 1.2 \times 10^{-1} & 2.5 \times 10^{-4}\left({ }^{235} \mathrm{U}\right) \\ & & 2.3 \times 10^{-4}\left({ }^{238} \mathrm{U}\right) \\ \text { * CEDE = 50-year committed effective dose equivalent. } & \end{array}$

(DOE, 1988) 
Table 5-5. Offsite Doses from Atmospheric Releases of Natural Uranium

\begin{tabular}{|c|c|c|c|c|}
\hline \multirow[b]{2}{*}{ Year } & \multirow{2}{*}{$\begin{array}{l}\text { Release } \\
\mathrm{Ci} / \mathrm{yr} \text { (a) }\end{array}$} & \multicolumn{2}{|c|}{$\begin{array}{c}\text { Site Perimeter CEDE (b) } \\
\text { mrem }\end{array}$} & \multirow{2}{*}{$\begin{array}{l}\text { EDC (c) } \\
\text { person-rem } \\
\text { 80-km Pop }\end{array}$} \\
\hline & & Max Ind & Average Ind & \\
\hline 1955 & $3.06 \mathrm{e}-01$ & 0.166 & 0.152 & 10.53 \\
\hline 1956 & $1.19 \mathrm{e}-01$ & 0.065 & 0.059 & 4.09 \\
\hline 1957 & $2.25 \mathrm{e}-03$ & 0.001 & 0.001 & 0.08 \\
\hline 1958 & $1.60 e-03$ & 0.001 & 0.001 & 0.06 \\
\hline 1959 & $7.15 e-03$ & 0.004 & 0.004 & 0.25 \\
\hline 1960 & $2.00 \mathrm{e}-02$ & 0.011 & 0.010 & 0.69 \\
\hline 1961 & $1.02 e-02$ & 0.006 & 0.005 & 0.35 \\
\hline 1962 & $8.86 e-03$ & 0.005 & 0.004 & 0.30 \\
\hline 1963 & $3.15 e-02$ & 0.017 & 0.016 & 1.08 \\
\hline 1964 & $5.55 \mathrm{e}-02$ & 0.030 & 0.028 & 1.91 \\
\hline 1965 & $5.18 \mathrm{e}-02$ & 0.028 & 0.026 & 1.78 \\
\hline 1966 & $2.06 e-02$ & 0.011 & 0.010 & 0.71 \\
\hline 1967 & $1.92 e-02$ & 0.010 & 0.010 & 0.66 \\
\hline 1968 & $2.67 e-02$ & 0.014 & 0.013 & 0.92 \\
\hline 1969 & $6.87 e-02$ & 0.037 & 0.034 & 2.36 \\
\hline 1970 & $1.66 e-02$ & 0.009 & 0.008 & 0.57 \\
\hline 1971 & $5.17 e-03$ & 0.003 & 0.003 & 0.18 \\
\hline 1972 & $7.73 e-03$ & 0.004 & 0.004 & 0.27 \\
\hline 1973 & $5.11 e-03$ & 0.003 & 0.003 & 0.18 \\
\hline 1974 & $8.67 e-03$ & 0.005 & 0.004 & 0.30 \\
\hline 1975 & $4.73 e-03$ & 0.003 & 0.002 & 0.16 \\
\hline 1976 & $4.97 e-03$ & 0.003 & 0.002 & 0.17 \\
\hline 1977 & $1.57 e-03$ & 0.001 & 0.001 & 0.05 \\
\hline 1978 & $3.06 e-03$ & 0.002 & 0.002 & 0.11 \\
\hline 1979 & $2.44 e-03$ & 0.001 & 0.001 & 0.08 \\
\hline 1980 & $4.01 e-03$ & 0.002 & 0.002 & 0.14 \\
\hline 1981 & $6.07 e-03$ & 0.003 & 0.003 & 0.21 \\
\hline 1982 & $9.15 e-03$ & 0.005 & 0.005 & 0.31 \\
\hline 1983 & $4.47 e-03$ & 0.002 & 0.002 & 0.15 \\
\hline 1984 & $2.19 e-03$ & 0.001 & 0.001 & 0.08 \\
\hline 1985 & $2.54 \mathrm{e}-03$ & 0.001 & 0.001 & 0.09 \\
\hline 1986 & $1.57 e-03$ & 0.001 & 0.001 & 0.05 \\
\hline 1987 & $8.52 e-03$ & 0.005 & 0.004 & 0.29 \\
\hline 1988 & $1.47 e-03$ & 0.001 & 0.001 & 0.05 \\
\hline 1989 & $5.05 e-03$ & 0.003 & 0.003 & 0.17 \\
\hline$\Sigma$ & $8.54 e-01$ & 0.464 & 0.426 & 29.38 \\
\hline
\end{tabular}

(a) Release data from Cummins, Hetrick, and Martin, 1991.

(b) $\mathrm{CEDE}=$ committed effective dose equivalent.

(c) $\mathrm{EDC}=$ environmental dose commitment.

such individuals are known to exist.) The cumulative dose to this individual for the period 1955-1989 has been estimated as $0.5 \mathrm{mrem}$.

This value is believed to represent a bounding case dose unlikely to have been received by any individual actually living in the Central Savannah River Area as a result of SRS atmospheric uranium releases. Nevertheless, the cumulative dose of $0.5 \mathrm{mrem}$ is substantially below the current EPA limit on annual dose, 10 mrem (EPA. 1989a). Additionally, the cumulative dose is below the $1 \mathrm{mrem} / \mathrm{yr}$ value recognized by the National Council on Radiation Protection and 
Measurements (NCRP) as a negligible individual risk level (NCRP, 1987).

Because the contribution of SRS uranium releases to any one individual's total radiation dose is so small, it is necessary to pool the radiation exposures from a given population if an assessment of potential health risks is desired. The population dose within an 80-kilometer radius is a figure-of-merit frequently used to make such an assessment.

The population doses reported in Table 5-5 are based on 1980 census data $(555,100$ people within $80 \mathrm{~km})$ and current meteorological and dose factor data. If it is assumed that this population has lived in the SRS vicinity throughout the period of site operation, the total collective effective dose received by that population from atmospheric uranium releases would be approximately 30 person-rem. As indicated in Table 5-5, this value is dominated by the contribution from 1955.

The risks associated with this collective dose are quite small. The ICRP risk estimate for the number of excess fatal cancers potentially induced by a collective dose of $\mathbf{3 0}$ person-rem is 0.02 . Conversely, in that population, at the current fatal cancer frequency of $16 \%$ (EPA, 1989b), there will be on the order of 90,000 fatal cancers from all other causes. Therefore, a causal relationship between any of the cancer deaths occurring in this population and the releases of uranium to the atmosphere from the SRS :s impossible to establish.

\section{Doses from Liquid Releases}

Dose equivalents potentially received by downstream consumers of Savannah River water and fish are shown in Table 5-6. The dose calculations are based on the total number of curies of natural Uranium released directly to onsite streams from SRS operations. The release levels reflect contributions from al! known effluents. Dose equivalents have been calculated for a "maximum" individual living just below SRS who subsists on a diet of untreated Savannah River water and fish of Savannah River origin. Such doses are believed to represent the bounding case for liquid uranium releases. Drinking water doses have been calculated for a "maximum" individual at the downstream water treatment plants (WTPs), and for the populations served by those WTPs.

Table 5-6 shows that the maximum dose to the "maximum" individual occurred in 1967, a year of relatively high uranium releases. The CEDE to this individual for that year's release rate has been estimated as $0.15 \mathrm{mrem}$. If these hypothetical exposure conditions are used as the bounding case for the 35-year period of uranium discharges, the cumulative dose to the maximum individual would be on the order of $0.6 \mathrm{mrem}$. Conversely, for the case of the "maximum" individual exposed through a downstream water treatment plant, the cumulative dose estimate is 0.4 mrem. In either case, the current radiation protection standards and guidelines of the EPA and DOE have not been exceeded.

With respect to the effect of liquid uranium releases on the populations downstream of the SRS, drinking water doses for users of the Beaufort-Jasper, SC (51,000 customers) and the Port Wentworth, GA (20,000 customers) water treatment plants have also been calculated. The Beaufort-Jasper plant services residential areas and, therefore, provides full-scale domestic water service. The Port Wentworth facility serves a commercial complex in which contact with treated Savannah River water is possible for industrial workers who consume tap water.

If the cumulative effective doses received by both of these populations are summed, the collective dose equivalent would be about 8 person-rem. Using the ICRP risk factor, the predicted impact of this collective dose is an estimated 0.004 excess fatal cancers in a population of 71,000 people- 11,400 of whom, at the current fatal cancer rate, are projected to succumb to cancer from all other sources. 
Table 5-6. Offsite Doses from Liquid Releases of Natural Uranium

\begin{tabular}{|c|c|c|c|c|c|c|c|c|c|c|}
\hline \multirow[b]{2}{*}{ Year } & \multirow[b]{2}{*}{$\begin{array}{l}\text { Release } \\
\text { Ci/yr (a) }\end{array}$} & \multirow{2}{*}{$\begin{array}{l}\text { River } \\
\text { Flow } \\
\text { Rate } 6 \\
301 \\
\text { (cfs)(a) }\end{array}$} & \multirow{2}{*}{$\begin{array}{l}\text { B-J } \\
\text { Derived } \\
\text { Flow } \\
\text { Rate } \\
\text { (cfs)(a)(b) }\end{array}$} & \multirow{2}{*}{$\begin{array}{l}\text { PW } \\
\text { Derived } \\
\text { Flow } \\
\text { Rate } \\
\text { (cfs)(a) }\end{array}$} & \multicolumn{3}{|c|}{ Max Ind Dose, mrem (c) } & \multicolumn{2}{|c|}{$\begin{array}{l}\text { WTP Pop Dose } \\
\text { person-rem(c)(d) }\end{array}$} & \multirow{2}{*}{$\begin{array}{l}\text { Total } \\
\text { Pop } \\
\text { Dose. } \\
\text { person } \\
\text { rem } \\
\text { (d)(e) } \\
\end{array}$} \\
\hline & & & & & Below & WTP & WTP & WTP & WTP & \\
\hline 1955 & $7.00 e-02$ & 5.974 & - & 7.528 & 0.003 & - & 0.002 & - & 0.014 & 0.014 \\
\hline 1956 & $5.20 \mathrm{e}-01$ & 6.309 & - & 7,949 & 0.020 & - & 0.013 & - & 0.099 & 0.101 \\
\hline 1957 & $1.05 e-01$ & 8.312 & - & 10.473 & 0.003 & - & 0.002 & - & 0.015 & 0.016 \\
\hline 1958 & $3.60 \mathrm{e}-02$ & 11.038 & - & 13,908 & 0.001 & - & 0.001 & - & 0.004 & 0.004 \\
\hline 1959 & $3.90 \mathrm{e}-02$ & 9.748 & - & 12.283 & 0.001 & - & 0.001 & - & 0.005 & 0.005 \\
\hline 1960 & $1.10 \mathrm{e}-01$ & 13.112 & - & 16.521 & 0.002 & - & 0.001 & - & 0.010 & 0.010 \\
\hline 1961 & $1.10 e-01$ & 10.909 & - & 13,745 & 0.002 & - & 0.002 & - & 0.012 & 0.012 \\
\hline 1962 & $5.30 \mathrm{e}-01$ & 10.580 & - & 13,331 & 0.012 & - & 0.008 & - & 0.060 & 0.062 \\
\hline 1963 & $1.95 \mathrm{e}+00$ & 11.138 & - & 14.034 & 0.043 & - & 0.028 & - & 0.211 & 0.215 \\
\hline 1964 & $4.96 e-01$ & 20.497 & - & 25,826 & 0.006 & - & 0.004 & - & 0.029 & 0.030 \\
\hline 1965 & $9.00 \mathrm{e}-01$ & 12.785 & 28.254 & 16.109 & 0.017 & 0.006 & 0.011 & 0.161 & 0.085 & 0.248 \\
\hline 1966 & $4.44 \mathrm{e}+00$ & 11.175 & 18.376 & 14.080 & 0.097 & 0.048 & 0.063 & 1.225 & 0.479 & 1.714 \\
\hline 1967 & $6.42 e+00$ & 10.573 & 22.066 & 13.322 & 0.148 & 0.058 & 0.096 & 1.475 & 0.733 & 2.222 \\
\hline 1968 & $4.21 e+00$ & 9.624 & 16.615 & 12,126 & 0.107 & 0.051 & 0.069 & 1.285 & 0.528 & 1.823 \\
\hline 1969 & $1.26 e+00$ & 10.945 & 22.034 & 13,790 & 0.028 & 0.011 & 0.018 & 0.290 & 0.139 & 0.431 \\
\hline 1970 & $6.82 e-01$ & 8.208 & 27.280 & 10,342 & 0.020 & 0.005 & 0.013 & 0.127 & 0.100 & 0.229 \\
\hline 1971 & $3.48 \mathrm{e}-01$ & 10.686 & 43.977 & 13.464 & 0.008 & 0.002 & 0.005 & 0.040 & 0.039 & 0.080 \\
\hline 1972 & $3.90 \mathrm{e}-01$ & 11.235 & 27.385 & 14,156 & 0.008 & 0.003 & 0.006 & 0.072 & 0.042 & 0.115 \\
\hline 1973 & $2.19 \mathrm{e}-01$ & 14,431 & 23.462 & 16.544 & 0.004 & 0.002 & 0.003 & 0.047 & 0.020 & 0.068 \\
\hline $1974^{\circ}$ & $3.49 \mathrm{e}-01$ & 11.101 & 22.598 & 13,182 & 0.008 & 0.003 & 0.005 & 0.078 & 0.040 & 0.119 \\
\hline 1975 & $4.4\lceil e-01$ & 15.408 & 30.978 & 18,987 & 0.007 & 0.003 & 0.005 & 0.072 & 0.035 & 0.108 \\
\hline 1976 & $3.63 \mathrm{e}-01$ & 13.914 & 35.172 & 16,660 & 0.006 & 0.002 & 0.004 & 0.052 & 0.033 & 0.086 \\
\hline 1977 & $8.44 \mathrm{e}-01$ & 11.646 & 19.841 & 15,306 & 0.018 & 0.009 & 0.011 & 0.216 & 0.084 & 0.301 \\
\hline 1978 & $5.59 \mathrm{e}-02$ & 10.522 & 24.332 & 11,450 & 0.001 & $<0.00 !$ & 0.001 & 0.012 & 0.007 & 0.019 \\
\hline 1979 & $6.40 e-02$ & 13.252 & 34.937 & 17,469 & 0.001 & $<0 . .001$ & 0.001 & 0.009 & 0.006 & 0.015 \\
\hline 1980 & $1.89 e-01$ & 13.202 & 30.464 & 17,219 & 0.003 & 0.001 & 0.002 & 0.031 & 0.017 & 0.048 \\
\hline 1981 & $1.71 \mathrm{e}-01$ & 6.599 & 11.698 & 8.579 & 0.006 & 0.003 & 0.004 & 0.074 & 0.030 & 0.105 \\
\hline 1982 & $4.21 e-02$ & 7.169 & 19.594 & 10,135 & 0.001 & $<0.001$ & 0.001 & 0.011 & 0.006 & 0.017 \\
\hline 1983 & $1.73 c-02$ & 12.348 & 12.760 & 14,723 & $<0.001$ & $<0.001$ & $<0.001$ & 0.007 & 0.002 & 0.009 \\
\hline 1984 & $9.70 \mathrm{e}-03$ & 12.759 & 26.368 & 17,196 & $<0.001$ & $<0.001$ & $<0.001$ & 0.002 & 0.001 & 0.003 \\
\hline 1985 & $1.35 \mathrm{e}-03$ & 7.167 & 9.290 & 8,959 & $<0.001$ & $<0.001$ & $<0.001$ & 0.001 & $<0.001$ & 0.001 \\
\hline 1986 & $4.39 e-02$ & 6.175 & 8.305 & 7.526 & 0.002 & 0.001 & 0.001 & 0.027 & 0.009 & 0.036 \\
\hline 1987 & $5.49 \mathrm{e}-03$ & 8.955 & 13.219 & 12.619 & $<0.001$ & $<0.001$ & $<0.001$ & 0.002 & 0.001 & 0.003 \\
\hline 1988 & $5.49 \mathrm{e}-03$ & 5.364 & 7.463 & 7,152 & $<0.001$ & $<0.001$ & $<0.001$ & 0.004 & 0.001 & 0.005 \\
\hline 1989 & $4.25 c-04$ & 7.832 & 8.462 & 8.650 & $<0.001$ & $<0.001$ & $<0.001$ & $<0.001$ & $<0.001$ & $<0.001$ \\
\hline$\Sigma$ & 25.44 & $\begin{array}{c}\text { (f) } \\
10,297\end{array}$ & $\begin{array}{c}\text { (f) } \\
21,797\end{array}$ & $\begin{array}{c}(\eta) \\
13,296\end{array}$ & 0.58 & 0.21 & 0.38 & 5.32 & 2.90 & 8.27 \\
\hline
\end{tabular}

(a) Release data from Cummins. Hetrick. and Martin, 1991. Flow rates based on USGS data at Highway 301 for the maximum individual below the Sitc. All other doses calculated from flow rates derived from tritium data.

(b) The Beaufor-Jasper water treatment plant began operation in 1965.

(c) Individual doses are CEDEs (committed effective dose equivalents).

(d) Drinking water contribution only. Population doses are CEDEs.

(e) Includes contributions from fish consumption, invertebrate consumption, shoreline habitation. recreational use. and water consumption.

(I) Averages 


\section{Summary}

A review of historical release data indicates that SRS contributions to uranium concentrations in the offsite environment have been too small to present a significant human health risk. This conclusion appears valid whether the assessment is based on the chemical or radiological hazards potentially associated with uranium compounds. No adverse health effects from SRS uranium releases for the period 1955-1989 have been detected or are anticipated. 


\section{References}

ACGIH (American Conference of Governmental Industrial Hygienists), 1988. Documentation of Threshold Limit Values and Biological Exposure Indices, 5th edition, Cincinnati, $\mathrm{OH}$.

ACGIH (American Conference of Governmental Industrial Hygienists), 1990. Guide to Occupational Exposure Values, Cincinnati, $\mathrm{OH}$.

Cooper, R. E., $1975 . \quad$ Computer Programs at SRL to Evaluate Environmental Effects of SRP Operations and Postulated Accidental Releases, DPST-75-384, E.I. du Pont de Nemours \& Company, Savannah River Laboratory, Aiken, SC.

Cummins, C. L., C. S. Hetrick, and D. K. Martin, 1991. Radioactive Releases at the Savannah River Site 1954-1989 (U), WSRC-RP-91-684, Savannah River Site, Aiken, SC.

Cummins, C. L., D. K. Martin, and J. L. Todd, 1990. Savannah River Site Environmental Report for 1989 , WSRC-IM-90-60 (2 Volumes), Westinghouse Savannah River Company, Savannah River Site, Aiken, SC.

Davis, H. A., D. K. Martin, and J. L. Todd, 1989. Savannah River Site Environmental Report for 1988, WSRCRP-89-59, Westinghouse Savannah River Company, Savannah River Site, Aiken, SC.

DOE (U.S. Department of Energy), 1988. Internal Dose Conversion Factors for Calculation of Dose to the Public, DOE/EH-007l, Washington, D.C.

Eckerman. K. F., F. J. Congel, A. K. Roecklein, and W. J. Pasciak, 1980. User's Guide to GASPAR Code, NUREG-0597, U.S. Nuclear Regulatory Commission, Washington, D.C.

EPA (U. S. Environmental Protection Agency), 1989a. 40 CFR Part 61, National Emission Standards for Hazardous Air Pollutants; Regulation of Radionuclides; Final Rule and Norice of Reconsideration. Federal Register, Vol. 54, No. 240.
EPA (U.S. Environmental Protection Agency), 1989b. Environmental Impact Statement NESHAPS for Radionuclides - Risk Assessment Methodology, Vol. I, EPA 520/1-89-005, Washington, D.C.

Marter, W. L., 1984. Environmental Dosimetry for-Normal Operations at SRP, DPST-83-270, Rev. 1, E.I. du Pont de Nemours \& Company, Savannah River Laboratory, Aiken, SC.

NCRP (National Council on Radiological Protection and Measurements), 1987. Recommendations on Limits for lonizing Radiation Exposure, NCRP Report No. 91, Washington, D.C.

NIOSH (National Institute for Occupational Safety and Health), 1985. Pocket Guide to Chemical Hazards, NIOSH Publication No. 78-210, U.S. Department of Health and Human Services, Cincinnati, $\mathrm{OH}$.

NRC, (U.S. Nuclear Regulatory Commission), 1977a. Method's for Estimating Atmospheric Transport and Dispersion of Gaseous Effluents in Routine Releases from Light-Water-Cooled Reactors, Regulatory Guide 1.111, Rev. 1, Washington, D.C.

NRC (U.S. Nuclear Regulatory Commission), 1977b. Calculation of Annual Doses to Man from Routine Releases of Reactor Effluents for the Purpose of Evaluating Compliance with 10 CFR 50. Appendix I, Regulatory Guide 1.109, Rev. 1, Washington, D.C.

Sagendorf, J. F., J. T. Goll, and W. F. Sandusky, 1982. XOQDOQ: Computer Program for the Meteorolngical Evaluation of Routine Effluent Releases at Nuclear Power Stations, NUREG/CR2919, U.S. Nuclear Regulatory Commission, Washington, D.C.

Simpson, D. B. and B. L. McGill, 1980. User's Manual for LADTAP II - A Computer Program for Calculating Radiation Exposure to Man from Routine Releases of Nuclear Reactor Effluents, NUREG/CR-1276, ORNL/ TDMC-1, Oak Ridge National Laboratory, Oak Ridge, TN. 


\section{Chapter 6. Environmental Monitoring Of Concentrations And Releases}

Environmental monitoring for uranium at SRS is carried out as part of special research programs as well as the routine effluent and environmental monitoring. As of 1989, samples analyzed for uranium included air filter samples from both onsite and offsite, water monitoring for several streams onsite and three locations offsite, groundwater (wells), and food samples. Effluent monitors are located at several atmospheric and aquatic locations, and these have been returning data for several years (Chapter 2). As uranium is a ubiquitous, naturally occurring radionuclide of very low specific activity, there was no specific measurement of uranium releases during the early years of operation. While accountability procedures were used to control the losses of ${ }^{235} \mathrm{U}$ enriched uranium, only gross alpha counting was used for most of the environmental analysis. Monitoring of environmental uranium away from the release points has been carried out since the early 1970 s but not with the regularity of the effluent release points. This has proven to be a particularly difficult aspect of environmental analysis work because it is frequently impossible to differentiate between natural uranium in the soil, uranium in ash from fossil fueled utilities, and uranium which may origing? from SRS.

Results from environmental monitoring for uranium are released to the public on ars artsual basis in the Savannah River Site Environmental Report. 


\section{Methods Of Detection}

Uranium can be detected with either chemical or nuclear methods. Chemically, there are a number of reactions that are specific to uranium that generate a colored compound. The uranium concentration is determined by measurement of the absorption of light at a specific wavelength. Though relatively widely used, these methods are rarely sensitive enough for use at SRS.

Detection of uranium can also be accomplished by neutron activation and analysis of the gamma radiation emitted by the activated products. While this method has high sensitivity, it requires a large amount of equipment which must be heavily shielded.

The method of detection most commonly used at SRS is alpha spectrometry. The three principal isotopes of uranium listed previously are alpha emitters with characteristic energies of $4.197 \mathrm{MeV}\left({ }^{238} \mathrm{U}\right), 4.40 \mathrm{MeV}\left({ }^{235} \mathrm{U}\right)$, and 4.776 $\mathrm{MeV}\left({ }^{2 \cdot 3} \mathrm{U}\right)$. These are accompanied by weak gamma emissions, but the alpha activity is normally used for identification purpuses. A fraction of the collected sample is dissolved if necessary and purified by solvent extraction. The uranium is then deposited on a metal disk either by electroplating or by direct evaporation of the solution. Once the sample has been mounted, it is placed under a calibrated detector that is able to differentiate between the alpha energies and detect the presence of uranium based on the unique alpha energies.

Recently, a new method of uranium analysis has been employed at SRS. This method makes use of the fluorescence of uranium compounds under laser light. The instrument measures the amount of fluorescent light emitted when the sample solution is struck by a laser of the correct wavelength. By the use of sophisticated electronic treatment of this signal, a concentration value for the uranium present in the sample is determined. Although the laser system is incapable of differentiating between the various isotopes of uranium as the alpha spectrometer is, this system possesses almost the same level of sensitivity and does not require as much sample preparation. This analysis method is currently being used in some areas and may displace the use of alpha spectrometry for much of the environmental monitoring where information concerning the isotopic composition of a sample is not required. 


\section{Atmospheric Monitoring}

Atmospheric releases of uranium, such as a release that might occur at separation areas or fuel/target fabrication facilities, are most likely to consist of uranium in a particulate form. Unlike iodine, uranium and its salts have no significant vapor pressure. The boiling points for uranium compounds are far too high to be reached in any portion of the separations or fabrication facilities. For this reason, the atmospheric releases of uranium do not migrate to the extent that tritium or other gaseous radionuclides do.

\section{Separation and Fabrication Facilities}

Health Protection Operations (HPO) maintains sampling streams for both separation lines ( $\mathrm{F}$ and $\mathrm{H}$ Area) and the fabrication facility, M Area. Sample streams of atmospheric effluent are taken just prior to the flow leaving the stack and entering the atmosphere. This reprejentative fraction of the stack gas is then passed through a particulate filtering system that recovers any entrained material. The filters are then leached with nitric acid and the uranium is selectively recovered by solvent extraction for alpha spectral analysis.

\section{Open Air Monitoring}

Samplers are located at five locations onsite, 14 locations at the site perimeter, and another 12 at locations approximately twenty-five mile from the site ( 25 mile radius locations). The various sampling locations are shown in Figure 6-1.
Portions of the filter extracts from the onsite locations are analyzed directly while aliquots of the perimeter and twenty-five mile radius samples are composited for analysis. Should any of the composited samples show excessive levels of uranium, the remaining aliquots of the original samples can be analyzed to find the particular station that had elevated activity levels.

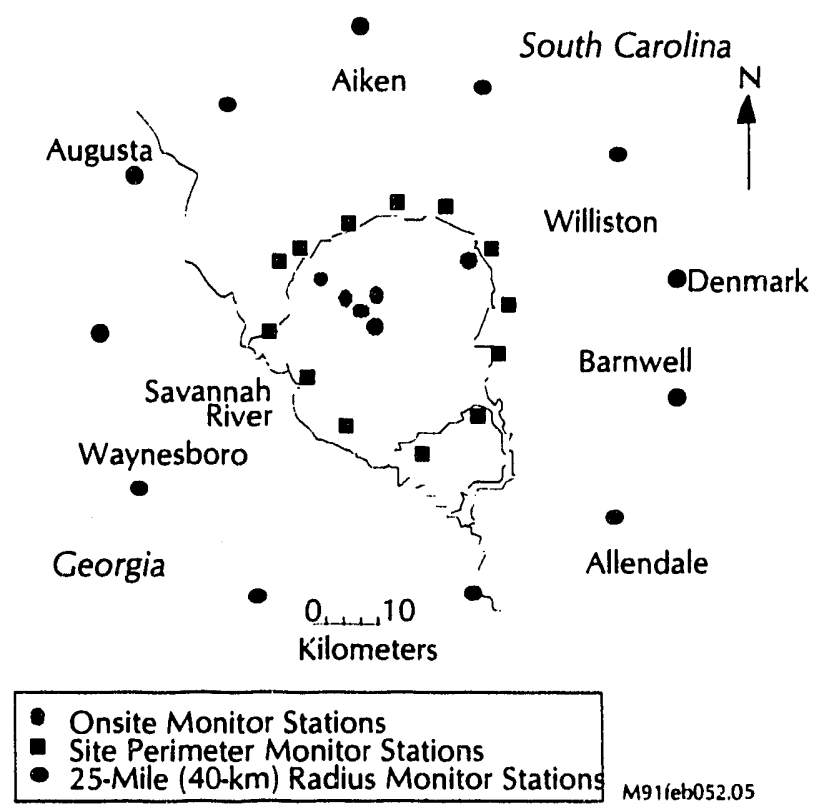

Figure 6-1. SRS Air Monitoring Locations 


\section{Water Monitoring}

Surface and groundwater sources are monitored for uranium on SRS. The purpose of monitoring in both cases is to detect any possible transport of material offsite to points where it might be introduced into the food chain or otherwise ingested by the population. At present all groundwater wells are located on SRS while surface water monitors are located onsite, along the Savannah River, and at three river locations down stream of SRS. Sampling frequency for these sites varies from weekly to annually, depending on the location.

\section{Uranium In Surface Water}

Uranium releases to streams can be either particulate material or dissolved uranium salts. Uranium metal itself is water reactive and is immediately oxidized to uranium oxide, $\mathrm{UO}_{2}$, which is essentially insoluble. Sampling of streams is carried out by one of several methods: Many locations have paddle-wheel samplers that are powered by the stream flow and sample at a rate proportional to the stream flow. Other methods used for sampling of streams and outfalls are electric (BrailsfordB) pumps, and dip samples. The paddle-wheel and pump methods provide an integrated sample over time while the dip sample is simply a grab sample for that particular time. The integrated samples generated by the automatic samplers are collected on a weekly basis. These samplers are gradually being replaced by microprocessor controlled samplers, which constantly measure the actual flow of the stream and change the sampling rate proportionally.

Samples are collected on a weekly basis at the sites indicated in Figure 6-2. The major streams, Upper Three Runs Creek,

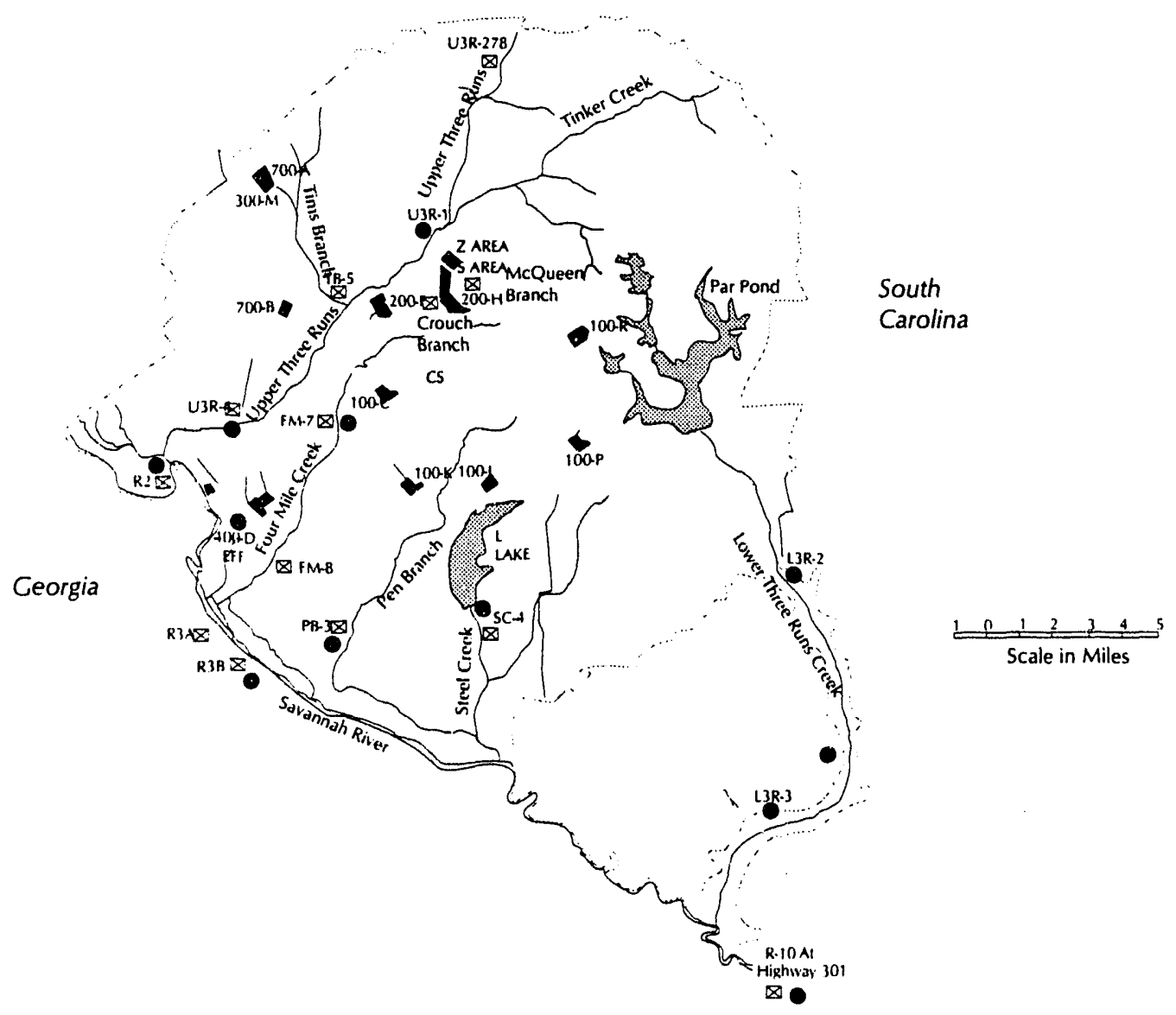

Figure 6-2. Surface Water Monitoring Locations 
Lower Three Runs Creek, Four Mile Creek, Steel Creek, Pen Branch, and Beaver Dam Creek, are all monitored as are some of the smaller tributaries. Samplers are also maintained in the outfall streams from the areas, and, in some cases, constant flow monitors are located on the source lines within the facilities themselves.

The Savannah River is sampled by paddle-wheel samplers at eight locations. The sampler locations are: (1) above SRS, (2) above the Plant Vogtle outlet, (3) below the Plant Vogtle outlet, (4 and 5) at Steel Creek landing (2 samplers), (6) Little Hell landing, and ( 7 and 8 ) Highway 301 bridge (2 samplers).

After water samples are collected, the uranium is separated by one of two methods.

(1) Triisooctyl amine (TIOA) method: The uranium (along with the plutonium) is extracted from one liter of water using a solution of TIOA in xylene. The organic layer, which contains the uranium and plutonium, is processed and plated onto a planchet. The sample is then counted in a gas flow proportional counter for twenty minutes followed by a count on an alpha spectrometer for 70,000 seconds.

(2) Hexone method: In this method, the uranium (along with the plutonium) is extracted from a liter of water using hexone. The hexone fraction, which contains the uranium and plutonium, is plated onto a planchet. The sample is then counted in a gas flow proportional counter for twenty minutes followed by a count in an alpha spectrometer for 70,000 seconds. These two separation methods are used for the outfall and the stream samples.

A limited number of water samples, generally from Tims Branch, are analyzed for uranium on a weekly basis by using laser fluorescence. In this case, the weekly composite sample is removed from the sampler and treated with a small amount of nitric acid to preserve the mineral content. A 1.5 $\mathrm{mL}$ aliquot is removed from the sample, $1 \mathrm{~mL}$ of a uranium specific complexing compound is added, and the concentration determined by comparison of the sample fluorescence to blanks and National Institute of Science and Technology (NIST) standards.

Additional samples are collected from varicus area effluent outfalls located onsite. An outfall is the termination of a trade waste drain, a storm drain or other runoff that is permitted on a normal basis without extensive holding and pretreatment. Samples are usually not collected at the point where the drainage pipe ends but somewhat downstream in a canal or drainage ditch.

\section{Uranium In Ground Water}

Although monitoring of gross alpha activity commenced in the early 1950s, uranium in groundwater has only been monitored at SRS since 1986. There are 260 weils on site that are currently monitored for uranium content out of a total of approximately 1200 wells that are used for environmental monitoring. Wells are selected for uranium sampling based on proximity to facilities such as former seepage basins, separation buildings, or waste treatment projects.

Samples are obtained by either bailing or pumping water from the wells in accordance with accepted EPA methods. Any well exhibiting elevated levels of uranium is monitored either annually or semiannually based on activity levels. Wells showing only background levels of uranium are monitored less frequentiy. Analysis of well water samples is carried out by solvent extraction and alpha spectrometry as described previously for surface water samples. 


\section{Uranium In Foods}

Though the primary source for uranium in the food chain is the uranium found in phosphate fertilizers (Chapter 1), food samples are collected in the areas surrounding SRS and analyzed for uranium content. This program was started in the early 1960s.

Food samples are collected at six locations, shown in Figure $6-3$, in a twenty-five mile radius surrounding the site. The food-stuffs collected usually consist of collards, fruits, grain, corn, chicken, eggs, pork, and beef. The collection locations are shown on the map in Figure 6-3. Samples are collected from these locations either on a quarterly, monthly or annual basis. Food samples are either ashed, homogenized, or lyophilized to produce an extract that can be dissolved and subjected to chemical separation and alpha spectrometry.

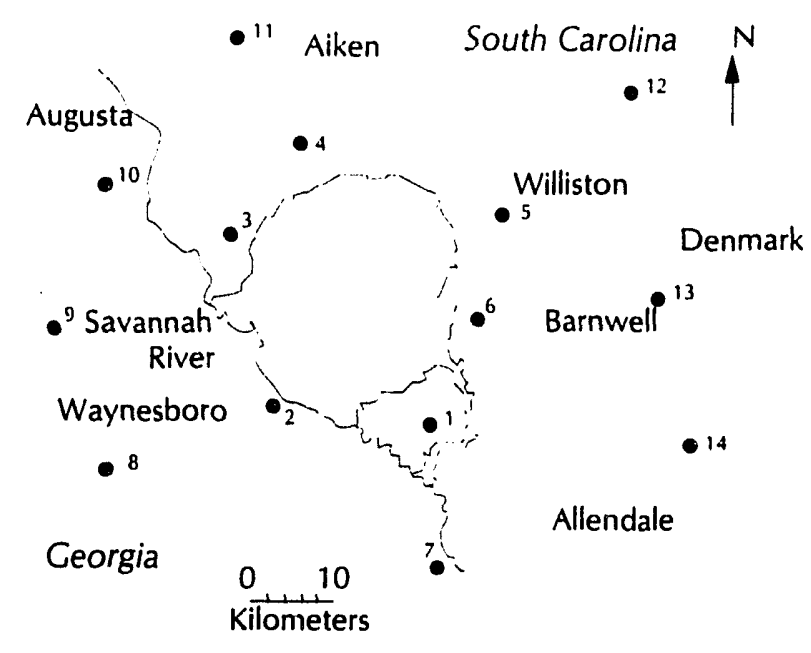

- Food Sample Locations

Figure 6-3. Food Sample Locations 


\section{Data Reporting}

Data collected from environmental monitoring is reported quarterly on an internal basis and externally in the annual Environmental Monitoring Report. 

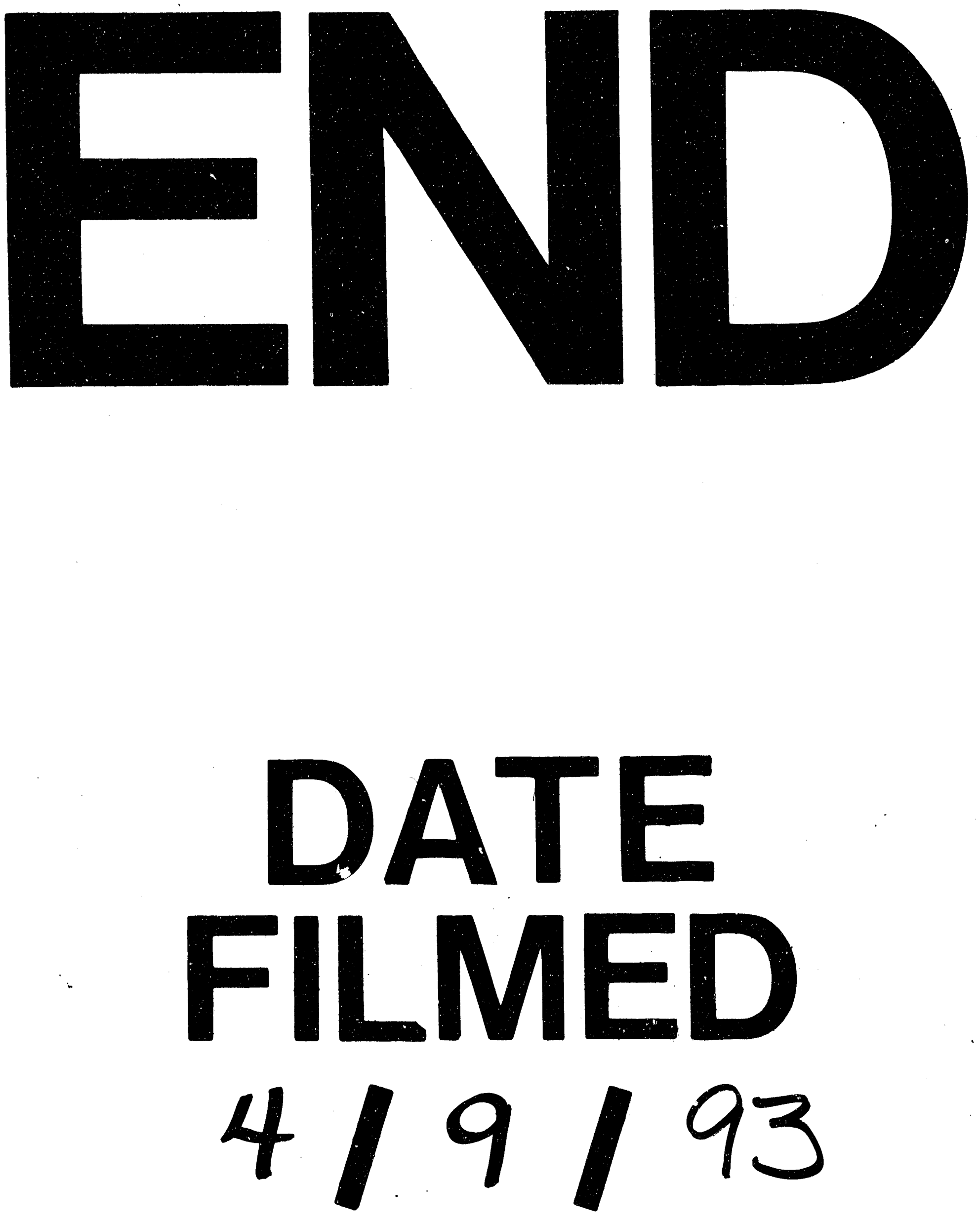